\title{
Defecography : a radiological study on anorectal function and related disorders
}

Citation for published version (APA):

Goei, R. (1990). Defecography : a radiological study on anorectal function and related disorders. [Doctoral Thesis, Maastricht University]. Maastricht University. https://doi.org/10.26481/dis.19900316rg

Document status and date:

Published: 01/01/1990

DOI:

10.26481/dis.19900316rg

Document Version:

Publisher's PDF, also known as Version of record

\section{Please check the document version of this publication:}

- A submitted manuscript is the version of the article upon submission and before peer-review. There can be important differences between the submitted version and the official published version of record.

People interested in the research are advised to contact the author for the final version of the publication, or visit the DOI to the publisher's website.

- The final author version and the galley proof are versions of the publication after peer review.

- The final published version features the final layout of the paper including the volume, issue and page numbers.

Link to publication

\footnotetext{
General rights rights.

- You may freely distribute the URL identifying the publication in the public portal. please follow below link for the End User Agreement:

www.umlib.nl/taverne-license

Take down policy

If you believe that this document breaches copyright please contact us at:

repository@maastrichtuniversity.nl

providing details and we will investigate your claim.
}

Copyright and moral rights for the publications made accessible in the public portal are retained by the authors and/or other copyright owners and it is a condition of accessing publications that users recognise and abide by the legal requirements associated with these

- Users may download and print one copy of any publication from the public portal for the purpose of private study or research.

- You may not further distribute the material or use it for any profit-making activity or commercial gain

If the publication is distributed under the terms of Article $25 \mathrm{fa}$ of the Dutch Copyright Act, indicated by the "Taverne" license above, 


\section{DEFECOGRAPHY}

$A$ radiological study on anorectal function and related disorders 



\section{DEFECOGRAPHY \\ $A$ radiological study on anorectal function and related disorders}

\section{PROEFSCHRIFT}

ter verkrijging van de graad van doctor aan de Rijksuniversiteit Limburg te Maastricht, op gezag van de Rector Magnificus, Prof. Dr. F.I.M. Bonke,

volgens het besluit van het College van Dekanen, in het openbaar te verdedigen op vrijdag, 16 maart 1990 om 14.00 uur

door

Reginald Goei

geboren te Salatiga (Midden-Java)

op 25 Juni 1948 
Promotores: Prof. Dr. J.M.A. van Engelshoven

Prof. Dr. B.K. Janevski

Co-promotor: Dr. C.G.M.I. Baeten

Beoordelingscommissie:

Prof. Dr. J. Drukker, voorzitter

Prof. Dr. P.B. Soeters

Prof. Dr. J.A. Flendrig

Prof. Dr. R.A. Janknegt

Prof. Dr. J. Pringot (Cliniques Universitaires Saint-Luc, Brussel)

CIP.DATA, KONINKLIJKE BIBLIOTHEEK, THE HAGUE

Goei, Reginald

Defecography : a radiological study on anorectal function and related disorders / Reginald Goei. - Maastricht :

Datawyse. - III.

Thesis Maastricht. - With ref. - With summary in Dutch.

ISBN 90-5291-020-0

SISO 605.13 UDC 616-072:616.36(043.3)

Subject heading: defecography.

Produktie en layout: Datawyse Maastricht, Ruud Leliveld Druk: Krips Repro Meppel 


\section{Aan Carine}

Aan Dustin, Jurian, Harold en Mylène 


\section{This thesis is based on the following publications:}

1. Goei R, Baeten C, Janevski B, van Engelshoven J. Solitary Rectal Ulcer Syndrome: Diagnosis with Defecography. AJR 1987; 149: 933-936.

2. Goei R, Baeten C, Arends JW. Solitary Rectal Ulcer Syndrome: Findings at Barium Enema Study and Defecography. Radiology 1988; 168: 303-306.

3. Goel $R$, van Engelshoven J, Schouten $H$, Baeten $C$, Stassen $C$. Anorectal Function: Defecographic Measurement in Asymptomatic Subjects. Radiology $1989 ; 173: 137-141$.

4. Goei R. Anorectal function in Patients with Defecation Disorders and Asymptomatic Subjects: Evaluation with Defecography. Radiology 1990; 174:121-123

5. Goei R, Baeten C. Rectal Prolapse and Rectal Intussusception: Detection and Postoperative Evaluation with Defecography. Radiology 1990; 174:124-126

6. Goei R, Kemerink G. Radiation Dose in Defecography. Radiology (accepted)

7. Goei R, Müller-Lissner S. Radiologische Methoden (Defekographie, Transitmessungen) in: Interdisziplinäre Gastroenterologie -Chronische Obstipation und Stuhlinkontinenz- 1989; 83-103. Springer-Verlag. Berlin-Heidelberg-New YorkLondon-Paris-Tokyo-Hong Kong. 


\section{CONTENTS}

\section{Chapter 1}

1.1 General Introduction

1.2 Aim of the study 10

1.3 Description of the study and patient material 12

\section{Chapter 2}

ANATOMY AND PHYSIOLOGY OF THE LEVATOR ANI

AND SPHINCTER ANI MUSCLES

2.1 Anatomy

2.1.1 Introduction

2.1.2 Review of the literature

2.1.3 Description of the cadaver dissection

2.2 Nerve Supply

22

2.3 Physiology

\section{Chapter 3}

DEFECOGRAPHY

A radiological method to study anorectal motility

Historical remarks and review of the literature

\section{Chapter 4}

THE CURRENT EXAMINATION TECHNIQUE AND

INTERPRETATIONS OF THE DEFECOGRAMS

4.1.1 Patient preparation

4.1.2 Contrast medium

4.1.3 Examination procedure 33

4.2 Definitions of normal findings according to the literature 34

4.3 Definitions of abnormal findings according to the literature 38

4.3.1 Intraanal rectal intussusception 38

4.3.2 Extraanal rectal intussusception 39

4.3.3 Mucosal prolapse 41

4.3.4 Rectocele 41 
4.3.5 Descending perineum syndrome

4.3.6 Spastic pelvic floor syndrome 46

4.3.7 Solitary rectal ulcer syndrome 46

\title{
Chapter 5
}

\author{
ANORECTAL FUNCTION \\ Defecographic measurement in asymptomatic \\ subjects
}

\section{Chapter 6}

ANORECTAL FUNCTION IN PATIENTS WITH DEFECATION DISORDERS AND ASYMPTOMATIC SLIBJECTS

Evaluation with Defecography

\section{Chapter 7}

SOLITARY RECTAL ULCER SYNDROME

Findings at barium enema study and defecography

\section{Chapter 8}

RECTAL INTUSSUSCEPTION AND RECTAL PROLAPSE

Detection and postoperative evaluation with defecography

\section{Chapter 9}

RADIATION DOSE IN DEFECOGRAPHY

\section{Chapter 10}

SUMMARY AND CONCLUSIONS

SUMMARY IN DUTCH

ACKNOWLEDGEMENTS 


\section{Chapter 1}

\subsection{GENERAL INTRODUCTION}

It is well known that many patients with abdominal pain have no organic disease. Actual practice shows that their symptoms arise from a functional disorder of the gut. In the true sense of the word, "functional" refers to the muscle activity of the bowel, rather than to psychological factors, although there is a frequent interaction between them.

A study of the members of the Virginia Gastroenterological Society in 1976 (1), revealed that $19 \%$ of the gastroenterological diagnosis were thought to be of functional origin. In the United Kingdom, among 2000 patients referred by general practitioners to a gastroenterology clinic, $47.5 \%$ had no organic disease. Abdominal pain with altered bowel habits, accounted for the complaints of about half of these patients (2). In a study of the Bristol Royal Infirmary (3) among 301 apparently healthy adults of roughly equal numbers of sexes and of all ages, $14 \%$ admitted to recurrent abdominal pain of colonic origin. This figure corresponds to the figures reported by Fowkes (4), who asked a multiracial group of apparently healthy doctors attending a course, to make a self-diagnosis of the Irritable Bowel Syndrome (IBS). Thirteen percent of the white doctors and $18 \%$ of the non-whites thought that they had the syndrome. In the Bristol study, a minority of one quarter of these individuals sought medical help for their bowel complaints. Sandler et al. (5) also reported that $62 \%$ of a similar group had never seen a doctor for their symptoms. Various explanations were given why so many of these people did not consult a doctor, such as: modest complaints, fear to undergo diagnostic studies and little faith in medical therapy (6).

It seems that IBS has to be regarded as an "iceberg disease" (7).

There is no unanimity in literature on the definition of the clinical criteria of IBS (8). Some authors (9) regard abdominal distress plus diarrhea or constipation in the absence of an organic disease, as a condition for the syndrome, others $(2,3)$ describe patients having defecation disorders without abdominal symptoms.

However, it is agreed that disturbances of defecation are an essential factor in IBS. The accompanying defecation disorder may consist of a variety of symptoms, including: loose or frequent stools alternating with 
hard or infrequent stools, constipation, straining at stool, feeling of incomplete evacuation, incontinence or diarrhea $(5,10,11)$.

Most studies on IBS (12-15) have concentrated on motility disorders of the colon. It is obvious that the accompanying alteration in bowell habits is ascribed to disturbed colonic motility, which in turn can be influenced by psychological factors (16).

However, recent studies $(17,18)$ indicate that defecation disorders such as constipation, could be caused by impaired anorectal function. Preston et al. (17) have shown electromyographically and radiologically that spasms of the pelvic floor muscles during straining in some cases are the cause of obstructed defecation. Reviewing the literature on this subject, it became obvious that difficulties with rectal emptying in the constipated patient are also manifested clinically: in the study of Thompson and Heaton (3), $10 \%$ of the subjects with functional bowel symptoms gave a history of straining at stool. Sandler et al. (5) reported that $52 \%$ of the investigated subjects answered that straining at stool was the main symptom, when asked to define constipation. Similar findings were reported by Moore-Gillon (19). There is a close relationship between straining at stool and faecal incontinence. Thirty to 66 percent of patients with incontinence, have a long history of straining at stool (20). The pathogenesis of incontinence has been described by Parks et al. (21), who suggested that a long period of straining at stool causes abnormal perineal descent, resulting in pudendal neuropathy and denervation of the external anal sphincter muscle, which is supplied by this nerve.

Although abnormal defecation has long been recognized as a cause of constipation. studies in patients with defecation disorders have been largely directed toward anatomical and functional abnormalities of the colon, and little attention has been given to the role of dysfunction of the anorectal region.

\subsection{AIM OF THE STUDY}

In addition to traditional history taking and clinical examination there exist a whole arsenal of investigations to evaluate anorectal dysfunction. Barium enema study and proctoscopy are static exarnination techniques, by which mucosal and anatomic abnormalities can be detected. Defecation disturbances in the absence of organic abnormalities, how- 
ever, are likely of functional origin, and thus should be evaluated accordingly.

Anorectal manometry measures the pressure in the anal canal, and in the rectal lumen produced by the puborectalis and sphincter ani muscles. Therefore, it provides information about the condition and physiology of these muscles. At present, the value of manometry is stil limited and pressure measurements are not very specific in proctological disorders, except in short segment Hirschsprungs disease (18). Electromyography can provide information about the function of the external anal sphincter and puborectalis muscles, to get a better understanding of the pathogenesis of several anorectal disorders, particularly those associated with faecal incontinence. However, electromyographic findings are also nonspecific (18).

Since manometry and electromyography are indirect methods, direct visualization of the functional anorectal disorder itself is warranted. This enables its classification, localization, and its extent to serve as an anatomic guide when surgical correction is contemplated.

Since clinical symptomatology is closely related to the act of defecation, a radiological study of the function of the anorectum during the actual evacuation of rectally injected contrast material, has been conducted. Although numerous authors have described defecography since 1952, it is not in wide clinical use. Probably technical difficulties in its performance account for its limited application. Moreover, the intention of most studies was to describe defecographic abnormalities in a single group of patients with defecation disturbances, without relating them to control subjects.

Therefore, the aims of this thesis are:

1. To describe a simplified and standardized technique of defecography.

2. To provide radiological parameters of anorectal function in subjects without defecation disorders.

3. To study, in which aspects anorectal function in patients with defecation disorders differs from those in asymptomatic subjects.

In addition to the aforementioned objectives, the following information will be provided as well:

4. The value of defecography and barium enema study in the evaluation of the Solitary Rectal Ulcer.

5. The value of defecography in the detection and postoperative evaluation of rectal prolapse and rectal intussusception.

6 . Estimations of the radiation dose delivered by defecography. 
16. Whitehead WE, Engel BT, Schuster MM. Irritable Bowel Syndrome. Physiological and Psychological Differences Between Diarrhea-Predominant and Constipation-Predominant Patients. Dig Dis Sci 1980;25: 404-413.

17. Preston DM, Lennard-Jones JE, Thomas BM. The balloon proctogram. Br J Surg $1984 ; 71: 29-32$.

18. Henry MM, Swash M. Coloproctology and the Pelvic Floor.Butterworths \& Co 1985: page: 80.

19. Victoria Moore-Gillon. Constipation: what does the patient mean? Journal of the Royal Society of Medicine 1984; 77: 108-110.

20. Kiff ES, Swash M. Slowed conduction in pudendal nerves in idiopathic (neurogenic) faecal incontinence. Br J Surg 1984; 71:614-616.

21. Parks $A G$, Swash $M$, Urich $H$. Sphincter denervation in anorectal incontinence and rectal prolapse. Gut 1977; 18: 656-665. 


\section{Chapter 2}

\section{ANATOMY AND PHYSIOLOGY OF THE LEVATOR ANI AND SPHINCTER ANI MUSCLES}

In the mechanism of defecation and the maintenance of anal continence, the levator ani and sphincter ani muscles play a primary role. In the first part of this chapter the topographic anatomy of these muscles will be described; in the second part a brief description of the nerve supply will be given and in the third part the physiology of the muscles with reference to normal defecation and anal continence will be discussed.

\section{$2.1 \quad$ ANATOMY}

\subsubsection{Introduction}

During defecography, the interaction between the levator ani musculature and the sphincter ani muscles with the dorsal part of the anorectum can be appreciated by means of fluoroscopy. Topographic insight in the exact relationship between these muscles and the anorectal region has been considered necessary. To meet this objective a study of the literature has been undertaken. In literature, including standard textbooks of anatomy (1-3), the anatomy illustrations of the levator ani muscles are given in frontal, cross sectional and sagittal views. In addition to this literature study, a cadaver study has been undertaken, with special interest in the dorsal aspect of the levator ani, sphincter ani and the anorectal region. From the cadaver, a three dimensional anatomic view 
of the relationship between the anorectal region and related musculature was obtained, which facilitates the understanding of the physiology of the anorectum.

\subsubsection{Review of the literature}

In the literature consulted (1-3), the parts of the anorectum are defined as follows: The anal canal is the terminal portion of the colon below the rectum. The rectum is that portion of the colon which is continuous with the sigmoid colon above and with the anal canal below. The rectosigmoid junction is situated at the smallest diameter of the cranial part of the rectum.

It is well known from standard literature $(1-3)$, that the levator ani muscles consists of three parts. This topographical division is based on origin and insertion, and not on physiology.

1. The lliococcygeus arises from the ischial spine and the posterior part of the tendinous arch. The muscle's fibers are directed medially, backwards and downwards. While the anterior bundles interdigitate at the anococcygeal raphe with the bundles of the opposite side, the posterior part of the muscle is attached to the coccyx (Fig.1)

2. The pubococcygeus is the central part of of the levator ani muscle, and its fibers arise from the anterior part of the tendinous arch and from the adjacent fascial structures over the internal obturator muscle, while the most medial fibers arise from the back of the body of the pubic bone. Like in case of the iliococcygeus, part of the bundles cross the midline at the anococcygeal raphe and are continued at the opposite side (Fig.1). The posterior part of the pubococcygeus is inserted to the coccyx. The muscle bundles of both the iliococcygeus and the pubococcygeus form a funnel shaped unit with a grossly cranio-caudal arrangement, with its apex at the distal rectum (Fig.2).

3. The puborectalis is a vertically lying muscle with its origin at the back of the lowest part of the pubic bone. The muscle fibers pass backwards and downwards around the dorsal aspect of the anorectal junction, without any interposition of tendinous fibers, forming the wellknown $\mathrm{U}$-shaped loop and they bring about the sharp anorectal angulation (Fig.1 and 2).

The morphology of the external anal sphincter has been investigated extensively by Shafik (4) who found the muscle to consist of three parts: (1) The deep external sphincter represents the most cranial part of the muscle. The posterior part of its fibers is fused together with the caudal 


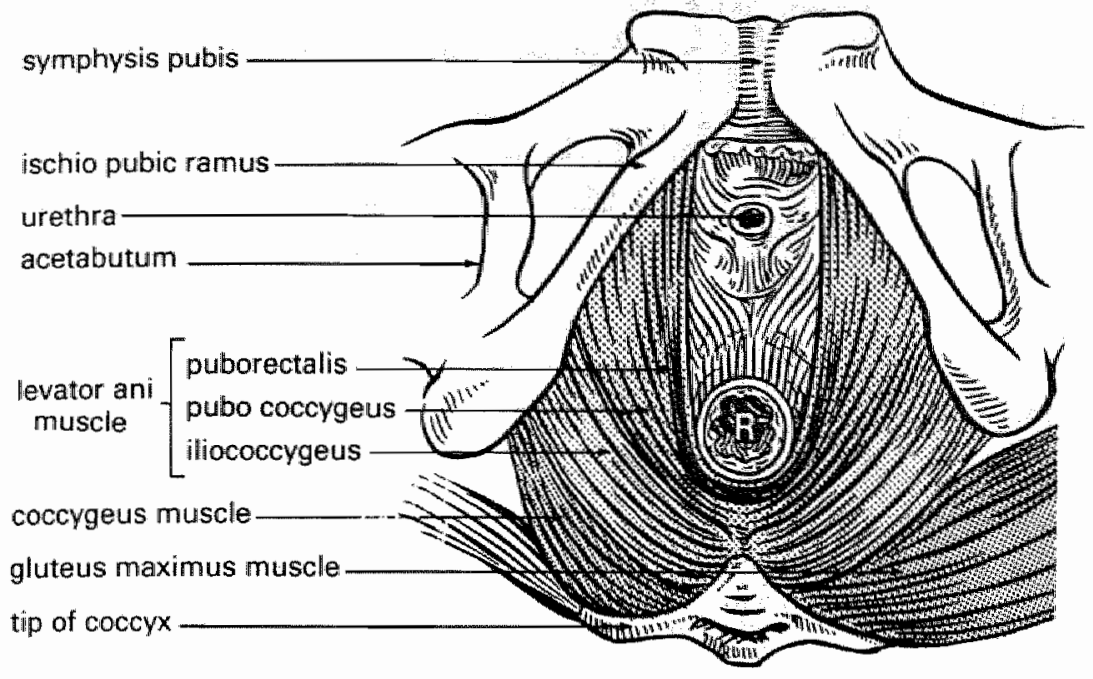

Figure 1. Caudal view of the pelvic floor.

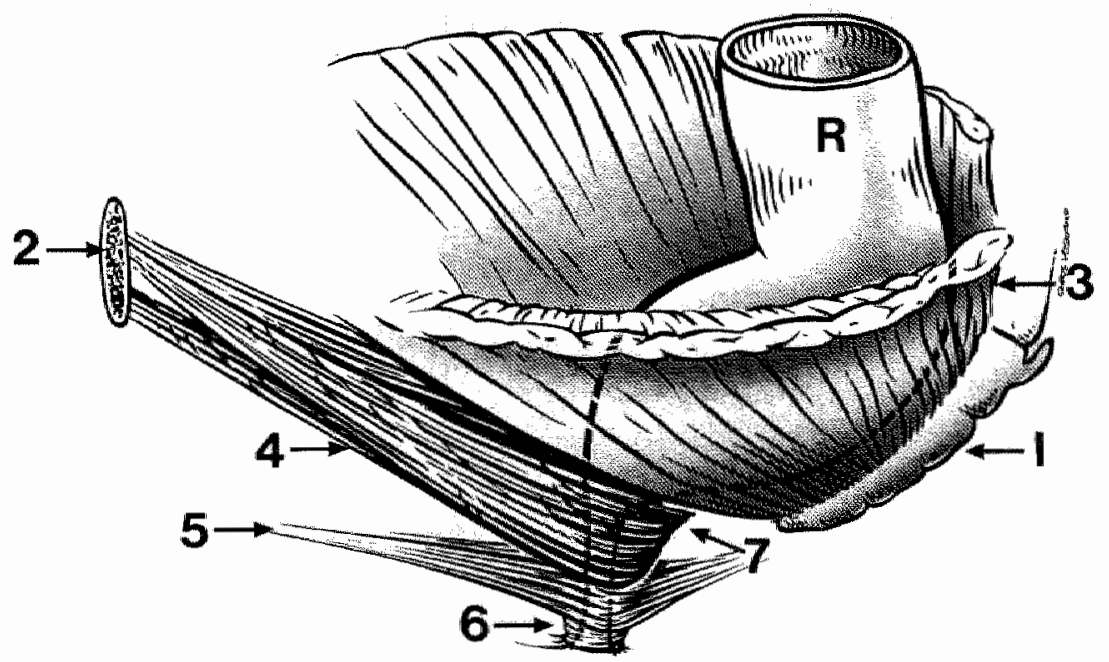

Figure 2. Schematic lateral view on the levator ani and external sphincter ani muscles. $R=$ rectum; $1=$ coccyx ; 2 = pubic symphysis; $3=1$ ilococcygeus and pubococcygeus; $4=$ top loop muscles (puborectalis and deep external sphincter); $5=$ superficial external sphincter; $6=$ subcutaneous external sphincter; $7=$ anorectal angle 


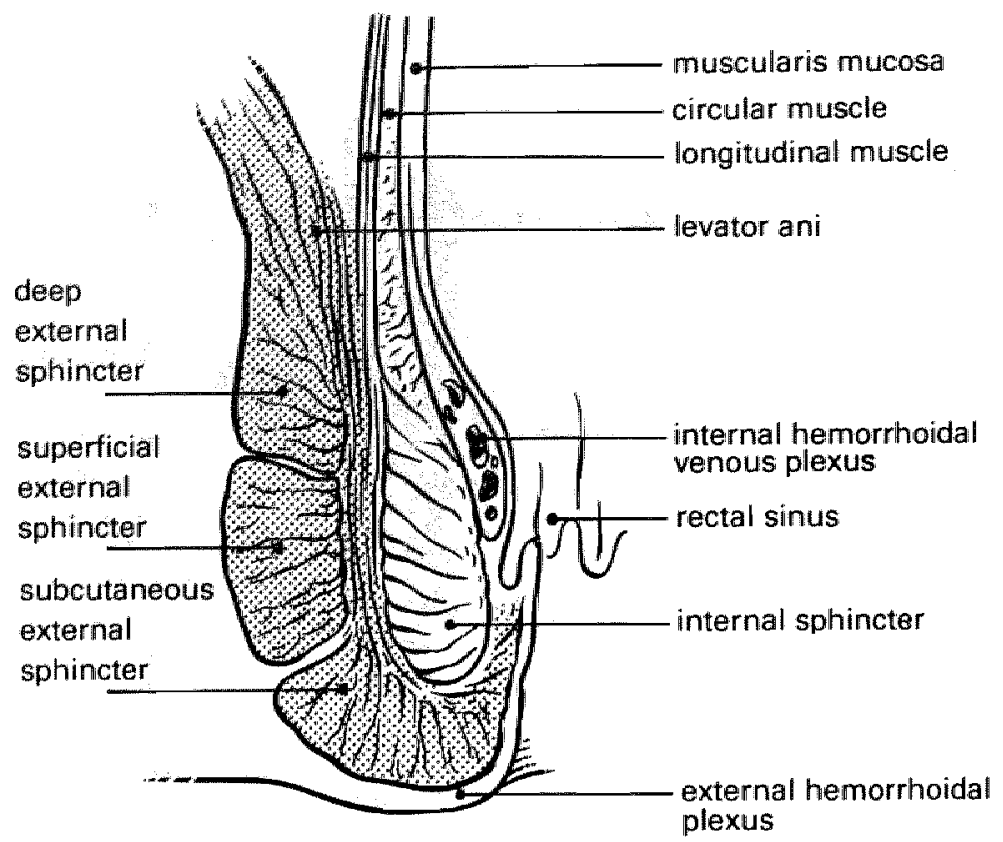

Figure 3. Frontal view of anorectum with the muscular layers.

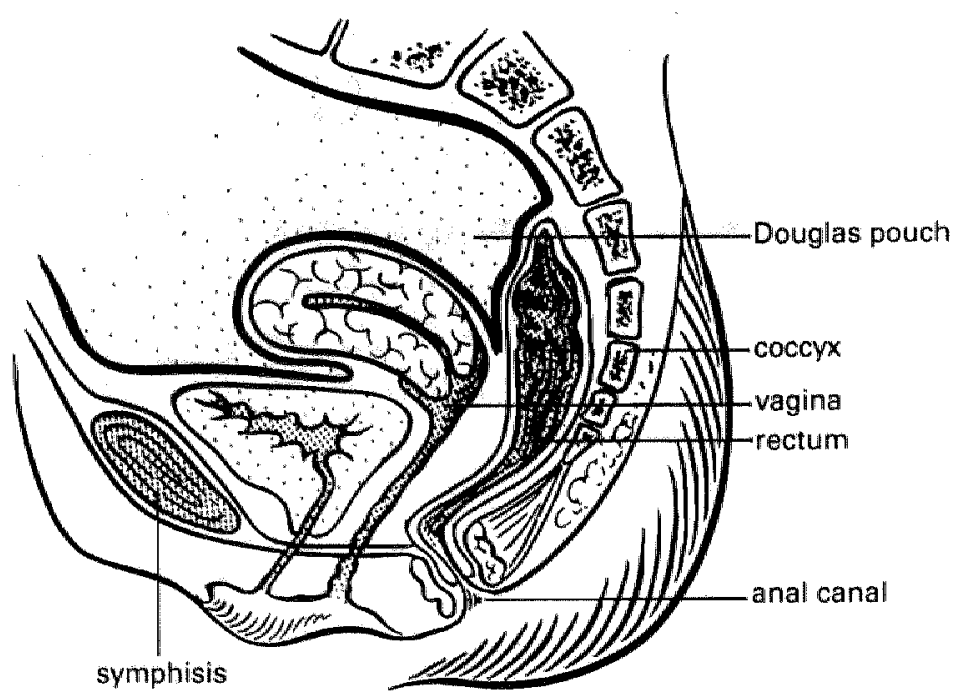

Figure 4. Schematic drawing of midsagittal view of the female pelvis. 
part of the puborectalis. These muscles act as a unit and are called the "top loop" muscle (Fig.2). The anterior part of the fibers of the deep external sphincter crosses the midline to join the fibers of the deep transversus perinei muscle which is attached to the ischium.

(2) The superficial external sfincter is an elliptical muscle originating from the anococcygeal ligament. It surrounds the anal canal and is inserted in the perineum (Fig.2).

(3) The subcutaneous external sphincter, represents an annular band encircling the lowermost portion of the anal canal, to insert into the perianal skin (Fig.2).

Centrally, the external anal sphincter muscle borders on the longitudinal muscle which starts at the level of the anorectal junction, extending alongside the anal canal, to terminate blindly above the subcutaneous external sphincter. The longitudinal muscle is formed by extensions of the top loop muscles, the pubococcygeus and the longitudinal muscle of the rectum (Fig.3).

The innermost muscular layer of the anal canal is formed by the internal sphincter, which is a thickened terminal portion of the circular muscle of the rectum encircling the anal canal (Fig.7). Like the longitudinal muscle, the internal sphincter muscle ends just cranial to the subcutaneous external sphincter.

\subsubsection{Description of the cadaver dissection}

One adult female specimen of 70 years of age was selected for gross anatomical dissection. The specimen was perfused with a standard solution consisting of $20 \%$ glycerin, $20 \%$ ethanol, and $4 \%$ formaldehyde. After the injection, the specimen was postfixed by submerging it in a bath of $2 \%$ formalin and $20 \%$ ethanol, during 2 months.

Six months after fixation the specimen was used for this study. The pelvis was isolated by transsecting the trunk at the level of the umbilicus and about $10 \mathrm{~cm}$ caudal from the trochanter minor.

Firstly, the specimen was examined ventrally to study the peritoneal reflections. Except for the rectum, the intestines, bladder and internal genital organs, were removed.

It appeared that the upper two thirds of the anterior and lateral surfaces of the rectum were covered by peritoneum, which was reflected from the

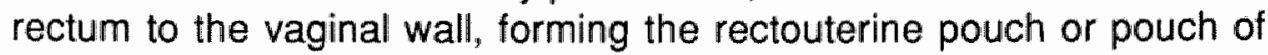
Douglas as displayed schematically on figure 4. 
Afterwards, the specimen was examined dorsally. The boundary of the anal canal and the rectum, was determined roughly by digital examination, and was situated at the point where the narrowness of the anal canal ended. This point was marked by use of a pin's head and the length of the anal canal was estimated at $2 \mathrm{~cm}$.

Exploration of the levator ani muscles was started by making the following incisions in the skin: one median incision over the cranial part of the sacrum, two paramedian incisions on both sides extending from the caudal part of the sacrum to the perineum and two transversal incisions $5 \mathrm{~cm}$ caudal from the trochanter minor towards the perineum. The skin was then removed from medial to lateral by sharp dissection. The skin of the anal region was removed from cranial to caudal, and afterwards the subcutaneous fat was dissected bluntly from the underlying connective tissue, separating it from the gluteus maximus muscle, sacrum and coccyx.

To explore the levator ani muscles the gluteal muscles were intersected obliquely from caudo-medial to cranio-lateral and the proximal part of these muscles was removed. By bluntly removing the fat tissue of the fossa ischiorectalis, the levator ani muscles and the external sphincter muscles came into view. The various parts of the levator ani musculature and the surrounding structures were identified by following their courses from origin to insertion based on the available data and description in standard literature (1-3).

In order to identify the iliococcygeus and the pubococcygeus, part of the overlying coccygeus, which is partly incorporated in the sacrospinal ligament, was resected. However, only a small part of the iliococcygeus and pubococcygeus could be identified (Fig.5). To preserve the continuity of the pelvic diaphragm, it was decided not to resect any further.

Because the puborectalis plays a central role in the maintenance of anorectal continence and in the act of defecation, attertion was particularly focused on this muscle. It appeared in the specimen that the puborectalis forms a continuum with the iliococcygeus and pubococcygeus. Furthermore, the puborectalis is a flat muscle with a divergent course. Its broadest part measures about $5 \mathrm{~cm}$ and is attached to the dorsall part of the anorectal junction by means of fibrous tissue (Fig. 5 and 6).

Caudal from the puborectalis the external sphincter could be identified (Fig.5 and 6). Although Shafik (4) states that the two components of the top loop cannot be differentiated morphologically, in the cadaver speci- 


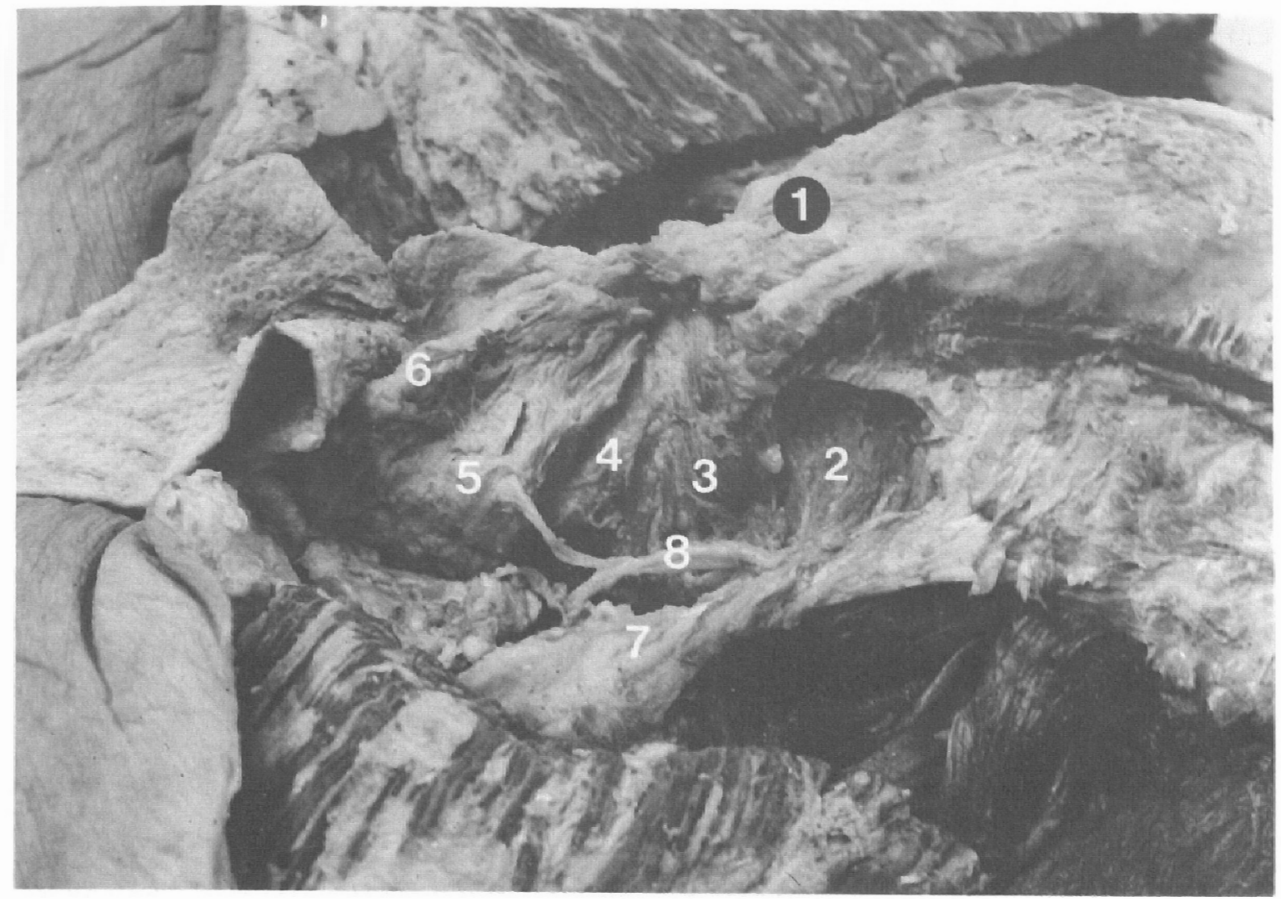

Figure 5. Dorsal view of the levator ani and external sphincter muscles. $1=$ coccyx; $2=$ iliococcygeus and pubococcygeus; $3=$ puborectalis; $4=$ deep external sphincter; $5=$ superficial external sphincter; $6=$ subcutaneous external sphincter; $7=$ sacrotuberous ligament; $8=$ branches of pudendal nerve.

men, the fibers of the puborectalis could be clearly distinguished from those of the deep external sphincter. (Fig.5). The puborectal part of the top loop has a reddish appearance due to the higher myoglobin content and its fibers are directed slightly anterocranially, whereas the fibers of the deep external sphincter have a whiter appearance and an antero caudal slinglike arrangement around the terminal rectum. Although the two muscles can be differentiated visually, no anatomic separation by fibrous tissue can be identified between them.

The deep external sphincter is separated by a fascial septum from the two other portions, namely the superficial external sphincter and the subcutaneous external sphincter (Fig.5).

To study the longitudinal muscle and the internal sphincter muscle, the septum separating the portions of the external sphincter muscles, was 


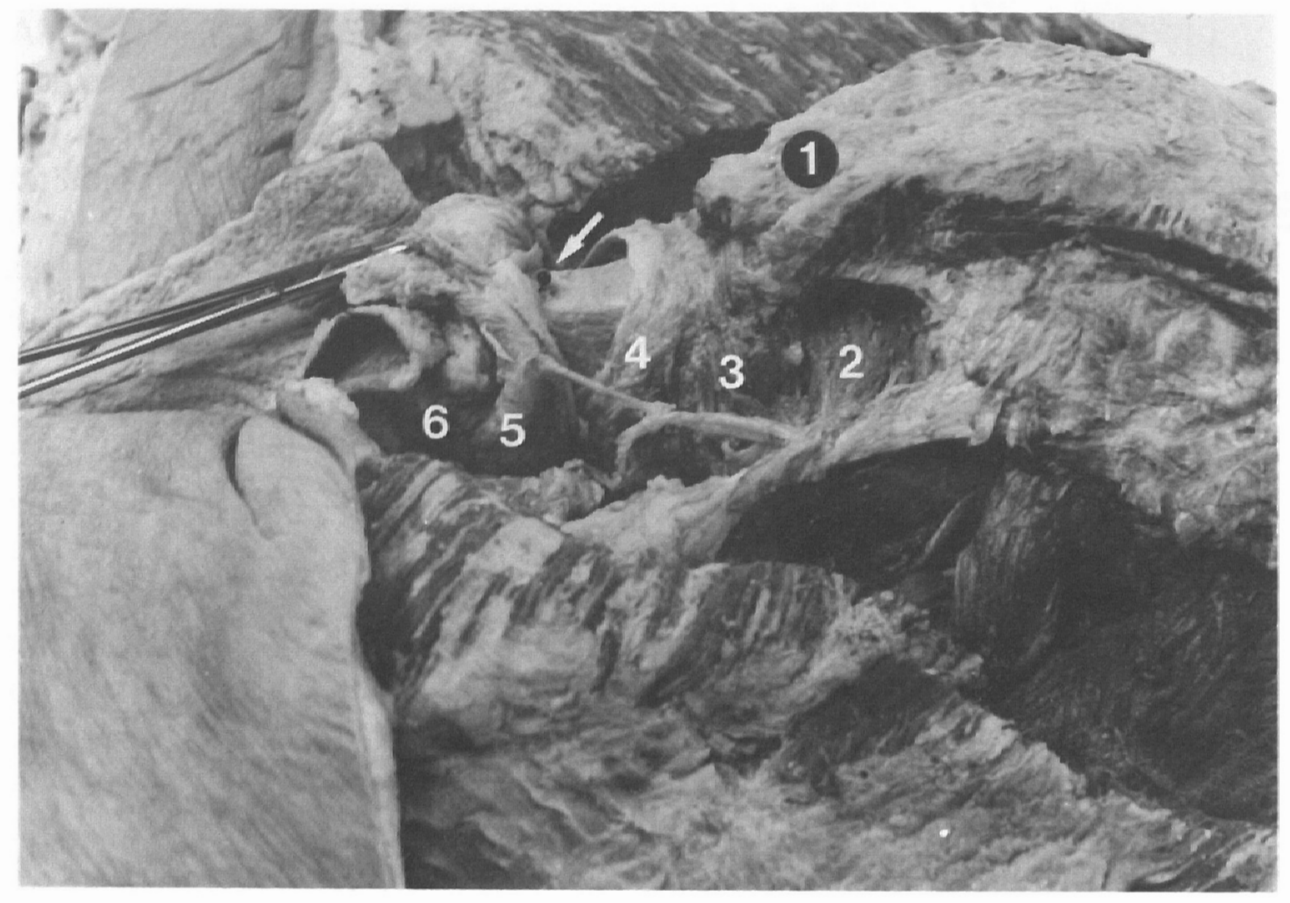

Figure 6. Dorsal view of the puborectalis and the deep external sphincter ("top loop"') muscles ( 3 and 4 ). $1=$ coccyx; $2=$ iliococcygeus and pubococcygeus; $3=$ puborectalis; $4=$ deep external sphincter; $5=$ superficial external sphincter; $6=$ subcutaneous external sphincter; note.- pin's head (arrow) = anorectal junction.

partially resected. The longitudinal muscle could easily be identified by the longitudinal arrangement of its fibers. The fibers of the internal anal sphincter were arranged almost perpendicular to the longitudinal muscle (Fig.7).

\subsection{NERVE SUPPLY}

Description of the innervation of the levator ani muscles, sphincter ani muscles and anorectum are given from a study of the literature consulted (1-3).

The sigmoid colon and rectum receive their innervation from the autonomic nervous system, whereas the anal canal and perianal area are 


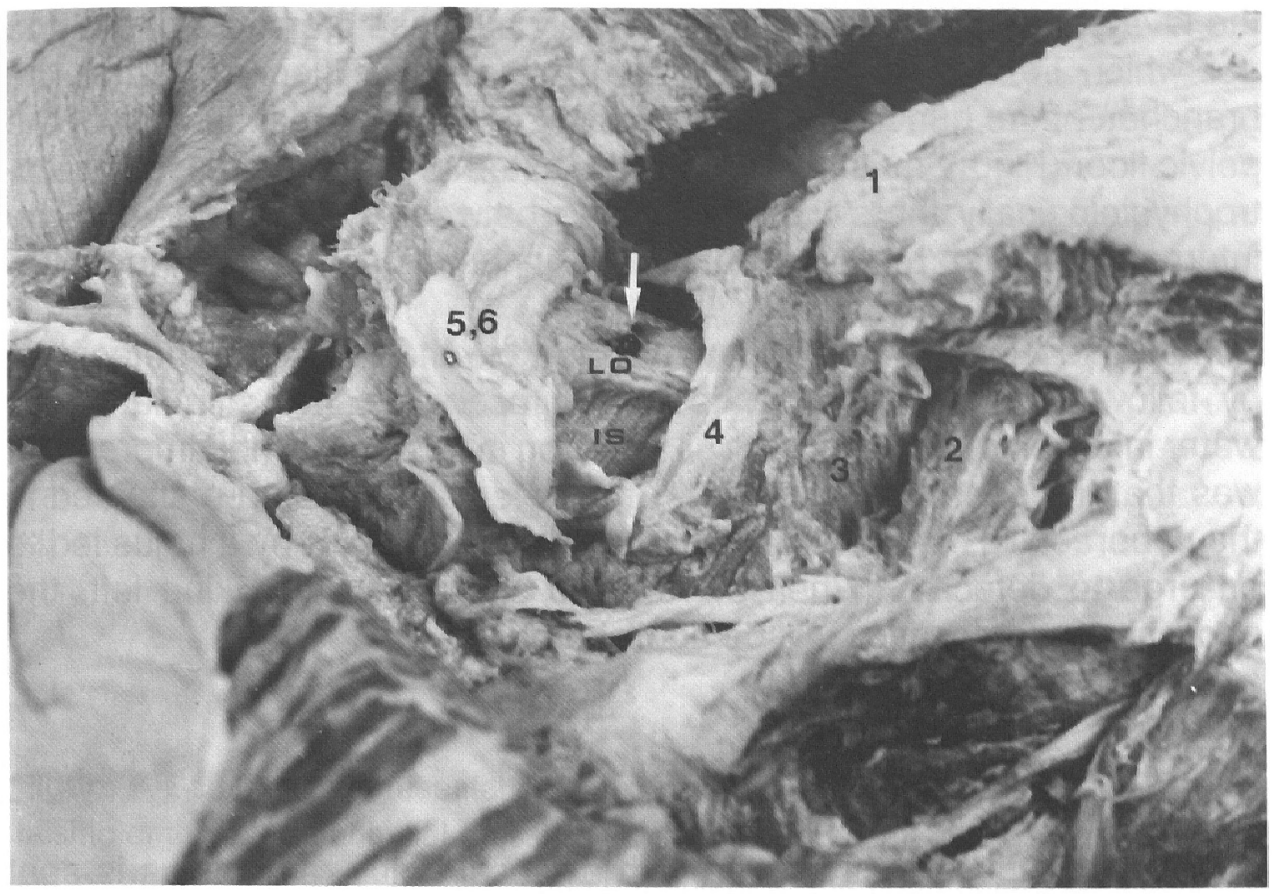

Figure 7. Dorsal view on parts of the longitudinal muscle (LO) and internal sphincter muscle (IS). $1=$ coccyx; $2=$ iliococcygeus and pubococcygeus; $3=$ puborectalis; $4=$ deep external sphincter; $5,6=$ superficial external sphincter and subcutaneous external sphincter; note.- pin's head (arrow) $=$ anorectal junction.

innervated by the somatic nervous system. Therefore, the sigmoid colon and rectum are insensitive to pain, and caudal of the anorectal line the sensitivity increases. Studies by Duthie and Gairns (7) revealed that the mucosa of the anal canal is supplied by a wealth of sensory receptors. Therefore, it is very sensitive to light touch, pain, heat and cold. This accounts for the fact that diseases and operative procedures in the anal canal and perianal area are usually associated with considerable pain. In the rectum on the contrary, no organized sensory endings have been found.

Standard descriptions of the nerve supply of the pelvic floor suggest that the levator ani muscles are innervated by the pudendal nerve and a direct branch from the s-3 and s-4 motor roots (3). However, electrophysiological studies by Percy et al. (8) suggest that in the majority of cases, 
the levator ani muscles, are supplied only by those branches of s-3 and s-4 which lie on the upper surface of the pelvic floor and that the branches of the pudendal nerve which lie on the perineal surface of the pelvic floor (Fig.2), mainly innervate the external sphincter muscle. Electrophysiologically there was no overlap between the two nerves. The internal sphincter receives autonomic innervation through the pelvic plexus.

Scharli and Kiesewetter (9) have studied the mechanism of defecation by following propulsive activities which occurred after stimulation by water injection or by distension of a balloon in this area. Their impression was that the sensory receptors for the defecation reflex are situated in the puborectalis muscle. Distension of the puborectalis by a bolus led to an urge to defecate. When there is no stimulus of this kind left, the necessity for defecation will be abolished.

\subsection{PHYSIOLOGY}

When the ampulla recti is filled with a faecal bolus, a stimulus is sent from the ampulla resulting in a peristaltic contraction of the sigmoid colon and in a contraction of the external anal sphincter and the puborectalis muscle. When the impuise reaches the cortex a consciousness to defecate is elicited from the ampulla, resulting in a relaxation of the internal sphincter. This event can be considered as a preparatory phase of defecation (11).

When it is socially convenient, the squatting position is adopted and by performing the valsalva manoeuvre the intraabdominal pressure is increased, resulting in an inhibition of the puborectalis and the external sphincter muscles. As a result of the relaxation of these muscles, which act as a unit, the anorectal angle widens and the anorectal junction descends. During defecation straining, the iliococcygeus and the pubococcygeus act reciprocally to the puborectalis and contract (4). On contraction of these muscles the anal canal is shortened and widened by an upward and lateral pull. Contraction of the pubococcygeus in turn, leads to contraction of the longitudinal muscle, which is its downward continuation, resulting in eversion of the anal orifice.

In this way the anorectum become funnel shaped to allow the passage of the bolus $(4,6)$. 


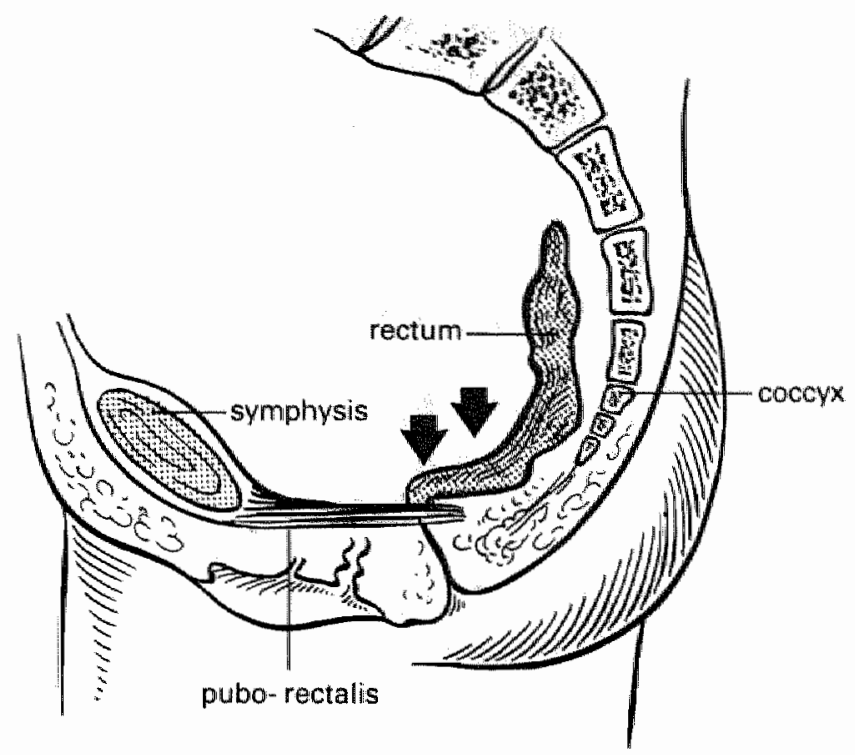

Figure 8. Schematic representation of the mechanical flutter valve principle. During raising of the intraabdominal pressure (arrows) the anterior wall is pressed against the posterior wall. Together with the contraction of the puborectalis continence is preserved.

In normal individuals, faecal continence is a physiologic state which is controlled by the central nervous system. It is the coordinated activity of the smooth and striated muscle of the anorectal region and the pelvic floor.

Foremost among the mechanisms in preserving continence is the acute anorectal angulation, which is the result of the contraction state of the puborectalis muscle at rest. As a result of the forward pull exerted by the puborectalis on the dorsal border of the anorectal junction, the posterior and anterior wall of this region are forced together and act as a mechanical flutter valve occluding completely the anal canal (12). This mechanism allows continence to be sustained, even in case of rapid and powerful raising of intraabdominal pressure such as occurs during coughing, vomitting or sneezing, whereby the anterior rectal wall is pushed downwards to occlude the upper lumen of the anal canal (Fig.8). Although it is generally accepted that the puborectalis probably is the most important element in the mechanism of continence, the concepts of this feature remain controversially in literature. Milligan and Morgan (12) 
found incontinence in individuals whose puborectalis had been irjured. Barnes (13) however, reported the results of a division of the puborectalis in nine women with severe constipation, whereafter none of the patients were incontinent for solid stool, although five cases showed incontinence for flatus, liquid stool and mucus. Wallace and Madden (14) partially resected the puborectalis in 72 patients with spasm of the muscle. After the procedure, none of the patients became incontinent.

Physiological studies of the pelvic floor musculature $(11,12,19-21)$ did not succeed in giving a clear picture of the interactions between the puborectalis, external and internal anal sphincters in order to maintain anal continence. Although most investigators have agreed on the existence of a high pressure zone in the anal canal, there is disagreement on its importance and on the part played by the internal and external anal sphincters with regard to its production $(19,21)$. Several authors $(19,21$, 22) estimates the contribution of the internal anal sphincter to the high resting pressure zone in the anal canal, ranging from $30 \%$ to $85 \%$. Bennett and Duthie (17) studied sixteen patients who underwent internal anal sphincterotomy for anal fissure. The amount of pressure was reduced by about $50 \%$. Nevertheless, after the procedure, the patients had only minor defects in anal continence, mainly the impaired passage of flatus. The remaining pressure after internal sphincterotomy was thought to be due to the activity of the external anal sphincter. However, this assumption was contradicted by the observation of Varma and Stephens (19) who reported four cases of children with congenital anorectal disorders in which both the internal and external sphincter were absent. The anal pressure in these cases did not differ from those in normal children. Probably this indicates that the puborectalis alone can maintain a pressure barrier in the anal canal (21).

It can be concluded from the above, that anal continence, most likely, is a combination of mechanical flap valve, acute anorectal angulation and high pressure factors as a result of close co-operation between the puborectalis and both anal sphincters. Despite controversial reports on the role of the puborectalis, the most widely held view in literature is that damage to the puborectalis probably results in major defects in continence, especially when the changes involve both the puborectalis and external anal sphincter (22).

In general, it can be stated that an increase of the activity of these muscles can cause constipation, whereas a diminished activity can lead to incontinence. 


\section{REFERENCES}

1. Pernkopf E. Atlas der Topographischen und Angewandien Anatomie des Menschen 1980; Urban \& Schwarzenberg. Munchen Wien Baltimore.

2. Sobotta. Atlas der Anatomie des Menschen, 2, Brust, Bauch, Becken, Untere Extremitaten, Haut 1982; 18 Auflage: 220-222.

3. Netter FH. The Ciba Collection of Medical illustrations. Lower Digestive Tract 1972; volume 3, part 2: 22, 32-34.

4. Shafik A. A new concept of the anatomy of the anal sphincter mechanism and the physiology of defecation. Il. Anatomy of the Levator Ani Muscle with Special Reference to Puborectalis. Investigative Urology 1975; 13: 175-182.

5. Shafik A. A new concept of the anal sphincter mechanism and the physiology of defecation. The External Anal Sphincter: A Triple-Loop System. Investigative Urology $1975 ; 12: 412-419$.

6. Shafik A. A new concept of the anatomy of the anal sphincter mechanism and the physiology of defecation. III. The Longitudinal Anal Muscle: Anatomy and Role in Anal Sphincter mechanism. Investigative Urology 1976; 13: 271-277.

7. Duthie HL, Gairns FW. Sensory nerve-endings and sensation in the anal region of man. Brit J Surg 1960; 47: 585-595.

8. Percy JP, Swash M, Neill ME, Parks AG. Electrophysiological Study of Motor Nerve Supply of Pelvic Flor. The Lancet 1980; January 3:16 -17.

9. Scharli AF, Kiesewetter WB. Defecation and Continence: Some New Concepts. Dis Colon Rectum 1970; 13: 81-107.

10. Ihre T. Studies on Anal function in Continent and Incontinent Patients. Scand. J. Gastroenterol 1974; 9 (Suppl. 25): 1-80.

11. Phillips SF, Edwards DAW. Some aspects of anal continence and defecation. Gut 1965; 6: 396-406.

12. Milligan ETC, Morgan CN. Surgical anatomy of the anal canal. Lancet $1934 ; 2$ : 1150-1156.

13. Barnes PRH, Hawley PR, Preston DM, Lennard-Jones JE. Experience of posterior division of the puborectalis muscle in the management of chronic constipation. Br.J.Surg 1985; 72: 475-477.

14. Wallace WC, Madden WM. Partial puborectalis resection: a new surgical technique for anorectal dysfunction. Southern Med J 1969;62: $1123-1126$.

15. Duthie HL, Watts JM. Contribution of the external anal sphincter to the pressure zone in the anal canal. Gut 1965; 6:

16. Haynes WG, Read NW. Anorectal activity in man during rectal infusion of saline: A dynamic assesment of the anal continence mechanism. J. Physiol 1982; 330: 45-56. 
17. Bennett RC, Duthie HL. The functional importance of the internal anal sphincter. Brit J Surg 1964; 51: 355-357.

18. Frenckner B, $v$. Euler Chr. Influence of pudendal block on the function of the anal sphincters. Gut 1975; 16:482-489.

19. Varma KK, Stephens D. Neuromuscular reflexes of rectal continence. Australian and New Zealand Journal of Surgery 1972; 41: 263-272.

20. Dickinson VA. Progress report. Maintenance of anal continence: a review of pelvic floor physiology. Gut 1978; 19: 1163-1174.

21. Duthie HL. Progress report. Anal continence. Gut 1971; 12: 844-852.

22. Bartolo DCC, Jarratt JA, Read MG, Donnelly TC, Read NW. The role of partial denervation of the puborectalis in idiopathic faecal incontinence. Br J Surg 1983; 70: $664-667$ 


\section{Chapter 3}

\section{DEFECOGRAPHY}

\section{A radiological method to study anorectal motility}

\section{Historical remarks and review of the literature}

The earliest publication on radiological study of the mechanism of defecation, originated from Lennart Walldén (1), who extensively investigated the role of an abnormally deep pouch of Douglas on the mechanism of defecation. This study was published as a thesis in 1952. The subjects were given a barium enema until the descending colon was reached. Thereafter, exposures of the pelvis were made in frontal and lateral projections while the patient evacuated the contrast medium in the upright position. In this way the effect of straining on the position of the pelvic floor could be studied. To assess the position of the rectogenital pouch during defecation, the small bowel loops were filled with orally administered contrast material. Walldén found a clear connection between a deep rectogenital pouch and difficulties in the evacuation of rectal contents, leading to constipation.

In 1953 Ekengren and Snellman (2) modified the technique, whereby the patient was examined sitting on a seat with a hole in the middle. The examination was then performed in three stages: with contrast material in the small intestine, after filling the rectum with a thick barium mixture, and after instilling contrast medium in the vagina. In connection with straining at stool, the authors found that in women, the uterus drops backwards and downwards, compressing the rectum, thus interfering with adequate evacuation. 
Snellman (3) investigated the etiology of rectal prolapse by means of evacuation studies, and concluded that prolapse is caused not only by an abnormally deep rectogenital pouch, but also by a weakening of the structures supporting the rectum.

In 1968 the scope of the study was extended by the same author (4) with cases of internal intussusception, which is considered a concealed form of rectal prolapse, and is regarded as its precursor. In this study, 2 types of internal intussusception were described: internal intussusception with an enterocele and another type without an enterocele. The former type was thought to be caused by a pathologically deep rectogenital pouch, while the latter was attributed to a weak support of the anterior rectal wall at the level of the peritoneal reflection.

Ahlbäck and Brodén (1978)(5) performed defecography in 781 patients with rectal evacuation difficulties. In their series, $40 \%$ had either internal intussusception or prolapse. The authors stressed the importance of defecography in early detection of internal intussusception, before it manifests itself clinically. Independent of the Swedish investigators, Burhenne, in the United States of America, recognized the importance of evacuation studies after enema filling in patients with altered bowel function (6). The technique was used in the diagnosis of vascular accidents of the gut accompanied by ulcerations. Pathologic segments showed no contraction during evacuation, whereas the remainder of the colon emptied normally.

Brown (1965) (7) firstly applied defecography to children. The detailed description of the normal movements of the anorectal region during defecation is of particular interest in his study. The patterns of motility of the anorectum in asymptomatic adults will be dealt with in chapter 5 of this thesis.

Other studies of defecography in children were performed by Kelly (1969) (8) and Marzoll et al. (1978) (9), who respectively applied the technique to the postoperative evaluation of children with anorectal malformations and Hirschsprung's disease. The anorectal angulation was used as a parameter reflecting levator ani physiology and the width of the anal canal was assumed to represent anal sphincter function. Measurements of these parameters in normal children was given by Berger and Landry in 1974 (10).

Despite its apparent clinical significance, defecography remained a specialized radiologic technique which did not become incorporated into routine clinical practice. Renewed interest in the eighties started with 
publications by Mahieu et al. in $1984(11,12)$ and by Ekberg et al. in 1985 (13), who described several pathologic conditions found at defecography, in patients with defecation disorders. A serious drawback of these communications, however, is the lack of parameters of anorectal motility in subjects without evacuation difficulties. One of the aims of this thesis is to provide some measurements on the basis of a study of individuals who were free of defecation related symptoms. To assess the ability of defecography to discriminate symptomatic from asymptomatic individuals, several defecographic measurements in these two patient groups will be compared. 


\section{REFERENCES}

1. Walldén L. Defecation block in cases of deep rectogenital pouch. Acta Chir Scand 1952; supplementum 165: 1-121.

2. Ekengren K, Snellman B. Roentgen appearances in mechanical rectal constipation. Acta Radiol 1953; 40: 447-456.

3. Snellman B. Complete prolapse of the rectum. Dis Colon Rectum 1961; 4 : 199-205.

4. Brodén B, Snellman B. Procidentia of the rectum studied with cineradiography: a contribution to the discussion of causative mechanism. Dis Colon Rectum $1968 ; 11: 330-347$.

5. Ahlbäck SO, Brodén B. Defekografi vid invagination och prolaps av rectum. Läkardingen 1978; $75: 668-673$.

6. Burhenne HJ. Intestinal evacuation study: a new roentgenologic technique. Radiol Clin 1963; 33: 79-84.

7. Brown B St J. Defecography or anorectal studies in children including cinefluorography observations. I de l'association canadienne des radiologistes 1965; 16: 66-76.

8. Kelly $\mathrm{JH}$. Cineradiography in anorectal malformations. J Pediat Surg 1969; 4: 538-546.

9. Marzoll I, Baudisch E, Schleicher Chr, Schickedanz H. Systematische untersuchungen mit der defäkographie in der prä- und postoperativen Megakolon-Diagnostik. Rad Diag 1978; 4: 485-494.

10. Berger D, Landry $M$. Funktionelle Untersuchung der Defäkation beim Kinde. Fortschr. Röngenstr. 1974; 121: 428-434.

11. Mahieu P, Pringot J, Bodart P. Defecography: I. Description of a new procedure and results in normal patients. Gastrointest Radiol 1984; 9: 247-251.

12. Mahieu P, Pringot J, Bodart P. Defecography: II. Contribution to the diagnosis of defecation disorders. Gastrointest Radiol 1984; 9: 253-261.

13. Ekberg O, Nylander G, Fork FT. Defecography. Radiology 1985; 155: 45-48. 


\section{Chapter 4}

\section{THE CURRENT EXAMINATION TECHNIQUE AND INTERPRETATIONS OF THE DEFECOGRAMS}

\subsubsection{Patient preparation}

As the rectum is usually empty, no extensive preparation is necessary. For hygienic reasons, however, the rectum should be cleansed with a single saline enema of 1 litre just before the examination.

\subsubsection{Contrast medium}

To imitate the usual consistency of stool, a special contrast medium was prepared by the hospital pharmacist. Fifty grams of a suspending agent (Carbopol 934 P, Goodrich, London, UK) is added to $5 \mathrm{~L}$ of a commercially available barium sulfate solution (Liquid Polibar, E-Z-EM Co, Westbury, NY), and gradually mixed with $340 \mathrm{ml}$ of sodium hydroxide until a thick paste of $\mathrm{pH} 7$ was formed.

\subsubsection{Examination procedure}

Three hundred milliliters of the contrast medium is to be injected via a syringe and an anal catheter into the rectum while the patient is lying on the left side. The patient is then asked to sit on a special designed seat which consists of a cylindrical radiolucent pot with a diameter of $40 \mathrm{~cm}$ and a height of $24 \mathrm{~cm}$. To minimize the radiation absorption differences between the soft tissue of the pelvis and the air below, three motorscooter tubes filled with water, are placed in the pot.

The pot is then placed on an aluminium chair, which in turn is mounted on the footrest of a remote-controlled fluoroscopic unit (Fig.1). During 


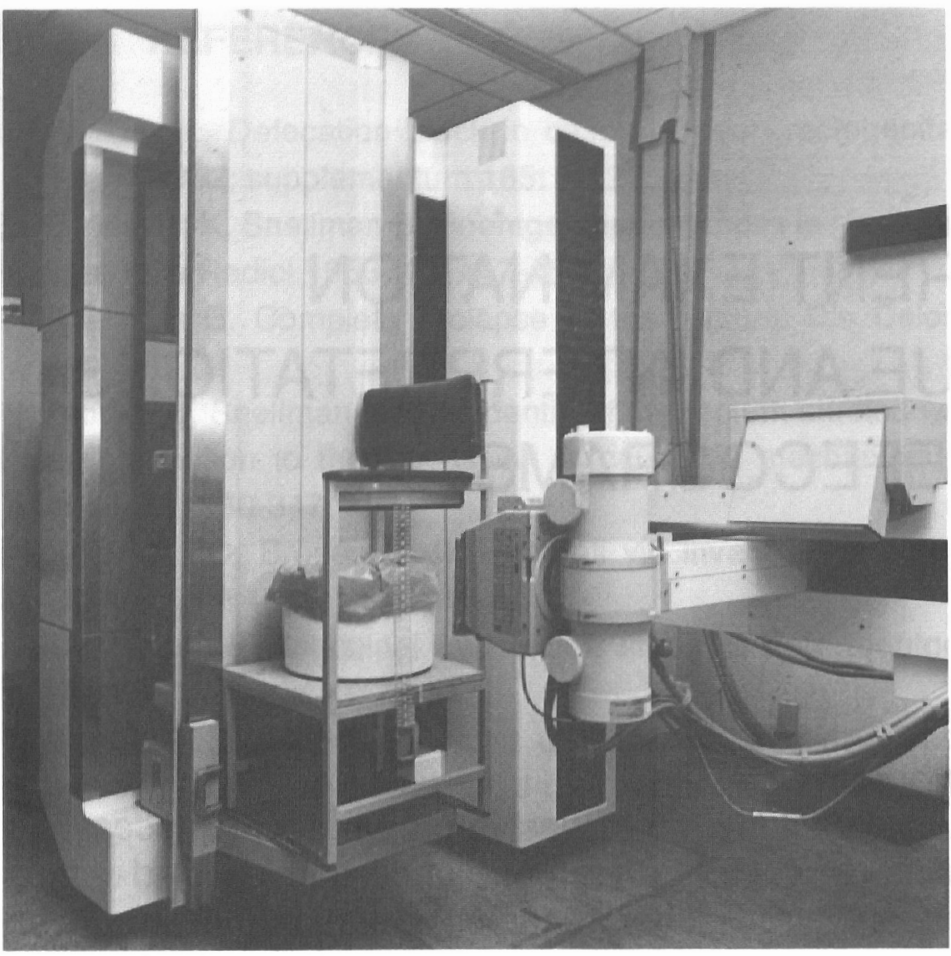

Figure 1.

Defecography chair mounted on the footrest of a fluoroscopic unit.

expelling of the contrast medium, the motility of the anorectum is observed fluoroscopically and radiographs are obtained with the use of a $105 \mathrm{~mm}$ camera and an exposure rate of $1 \mathrm{frame} / \mathrm{sec}$. or $1 \mathrm{frame} / 2 \mathrm{sec}$, depending on the speed of evacuation of the bolus. Usually 9-12 films suffice to document the entire act of defecation.

\subsection{DEFINITIONS OF NORMAL FINDINGS AT DEFECOGRAPHY ACCORDING TO THE LITERATURE}

In our institution defecography is performed according to a standard procedure. Firstly, the patient is asked to squeeze, by which the levator ani muscles, especially the puborectalis, contracts maximally.

This event causes an impression at the posterior border of the anorectal junction and an acute anorectal angulation (Fig.2a). Then the patient is asked to relax the levator ani muscles. At this stage the puborectalis is still contracted, but less than during squeezing, as can be seen by a 

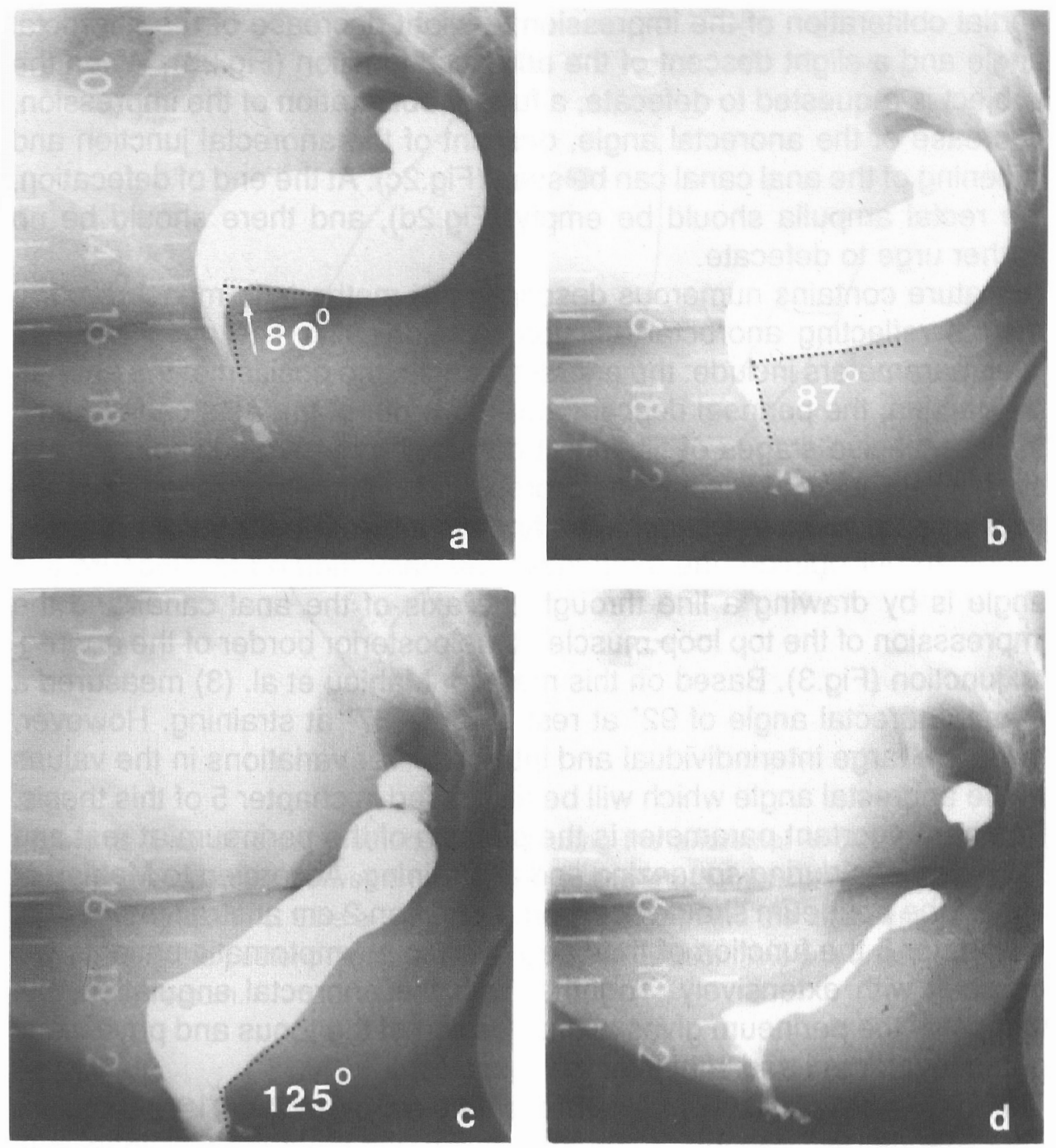

Figure 2. Normal defecogram. (a). At squeezing, there is an impression at the posterior border of the anorectal junction, caused by the puborectalis (arrow). The anorectal angle is acute $\left(80^{\circ}\right)$.(b). At rest, slight obliteration of the impression and slight decrease of the angulation, as a result of partial relaxation of the puborectalis. (c). At straining, complete relaxation of the puborectalis, resulting in further obliteration of the impression, and further decrease of the angulation. There is also a descent of the anorectal junction.(d). At the end of defecation there is almost complete evacuation of rectal contents. 
partial obliteration of the impression, a slight decrease of the anorectal angle and a slight descent of the anorectal junction (Fig.2b). When the subject is requested to defecate, a further obliteration of the impression, decrease of the anorectal angle, descent of the anorectal junction and widening of the anal canal can be seen (Fig.2c). At the end of defecation, the rectal ampulla should be empty (Fig.2d), and there should be no further urge to defecate.

Literature contains numerous description of methods to measure parameters reflecting anorectal function radiologically. The most frequent cited parameters include: the anorectal angle, the position of the anorectal junction, the perineal descent and the width of the anal canal during the succcesive stages of filming at defecography (squeezing, rest and straining). Figure 3 displays two proposed methods of measuring the anorectal angulation. Because the angle should reflect levator ani physiology, in our opinion, the most logic and easy method to measure this angle is by drawing a line through the axis of the anal canal and the impresssion of the top loop muscle at the posterior border of the anorectal junction (Fig.3). Based on this method, Mahieu et al. (3) measured a mean anorectal angle of $92^{\circ}$ at rest and of $137^{\circ}$ at straining. However, there are large interindividual and interobserver variations in the values of the anorectal angle which will be discussed in chapter 5 of this thesis. Another important parameter is the position of the perineum at rest and its excursions during squeezing and at straining. According to Mahieu et al. (3), the perineum should not drop more than $2 \mathrm{~cm}$ at straining. Again, in chapter 5 the function of the anorectum in asymptomatic patients will be dealt with extensively. Together with the anorectal angulation, the motility of the perineum gives an impression of the tonus and physiology of the levator ani and sphincter ani muscles.

The most widely held method to measure perineal motility, is to measure the distance between the anorectal junction and the pubococcygeal line, which connects the tip of the coccyx to the lower border of the pubic bone $(1,2)$ (Fig.4). On photographs, however, the exact position of the anorectal junction is difficult to assess and as a consequence of superposition of the femoral heads, the pubic bone is also difficult to delineate. For these reasons, we define the anorectal junction, arbitrarily, as the point where the two lines drawn to measure the anorectal angle intersect. The easiest way to measure perineal excursions is to measure the distances of the anorectal junction relative to the tip of the coccyx. 


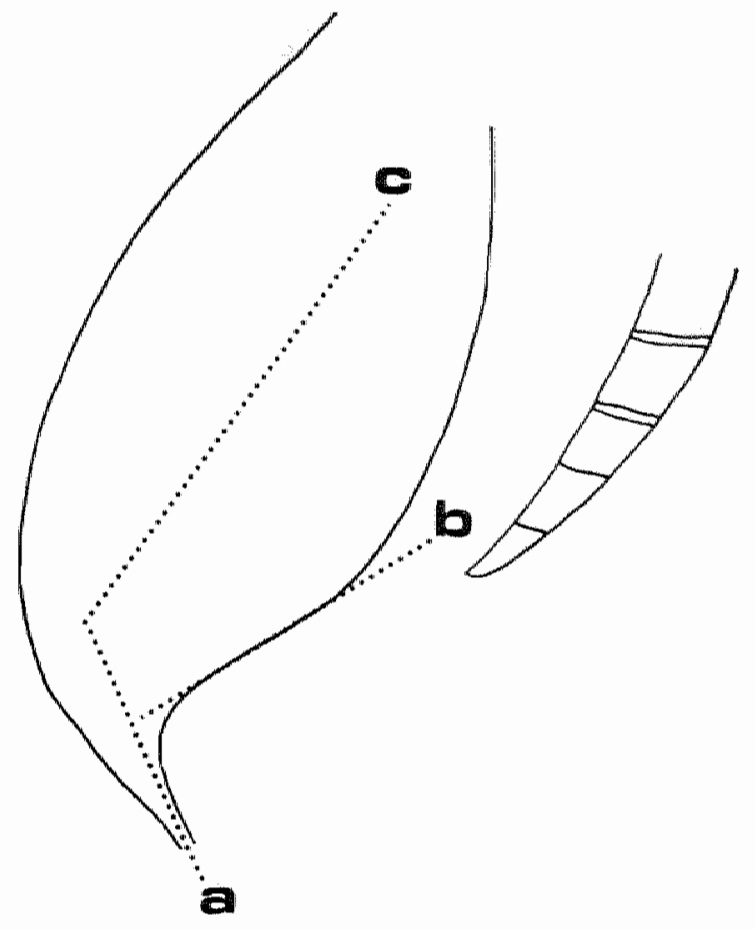

Figure 3. Two different methods of measuring the anorectal angle. One method measures the angle between line $a$ and $b$; the other measures the angulation between line $a$ and $c$. Line $a$ is drawn along the axis of the the anal canal, line $b$ is drawn along the posterior border of the anorectal junction, line $c$ is drawn along the axis of the rectum.

Furthermore, during defecography, close attention should be paid to the shape of the anorectal wall. According to descriptions in the literature this should remain smooth without outpocketings or infoldings during the evacuation of rectal contents (3)(Fig.2). 


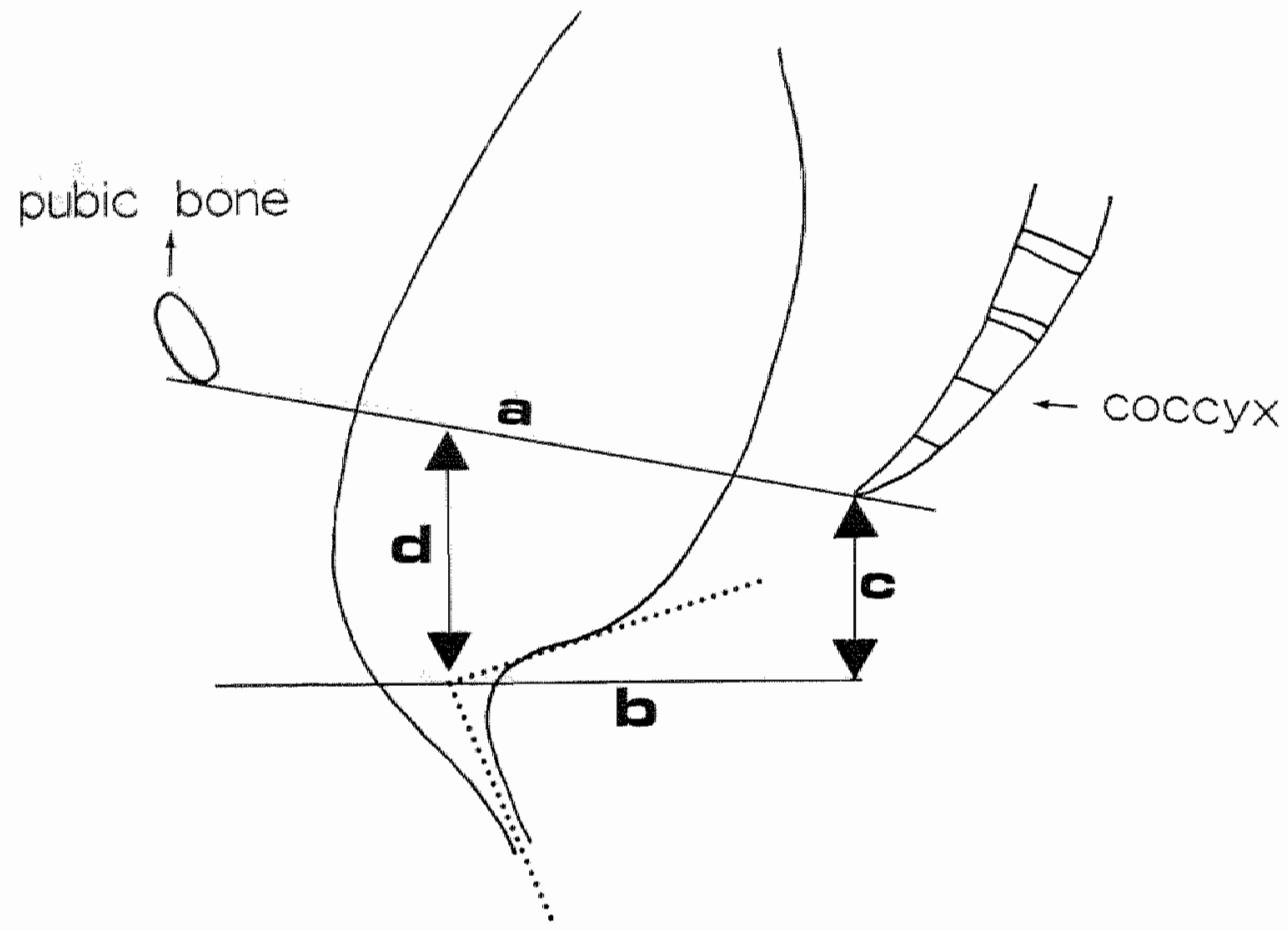

Figure 4. Two methods to measure perineal motility. Straight line a depicts the pubococcygeal line. Line $b$ is drawn through the level of the anorectal junction. One method measures the motility of the anorectal junction relative to the tip of the coccyx (double arrow c). Another, measures the excursions relative to the pubococcygeal line (double arrow d)

\subsection{DEFINITIONS OF ABNORMAL FINDINGS AT DEFECOGRAPHY ACCORDING TO THE LITERATURE}

\subsubsection{The intraanal rectal intussusception}

In this condition, invagination of the rectal wall into the distal rectal lumen or the anal canal occurred (4-7). The intussusception may involve the anterior rectal wall (Fig.5) or may be circular (Fig.6). When the patient strains the head of the intussusception blocks the anal canal and prevents further evacuation of rectal contents. This gives the patient a sensation of incomplete evacuation and leads to repeated straining. 

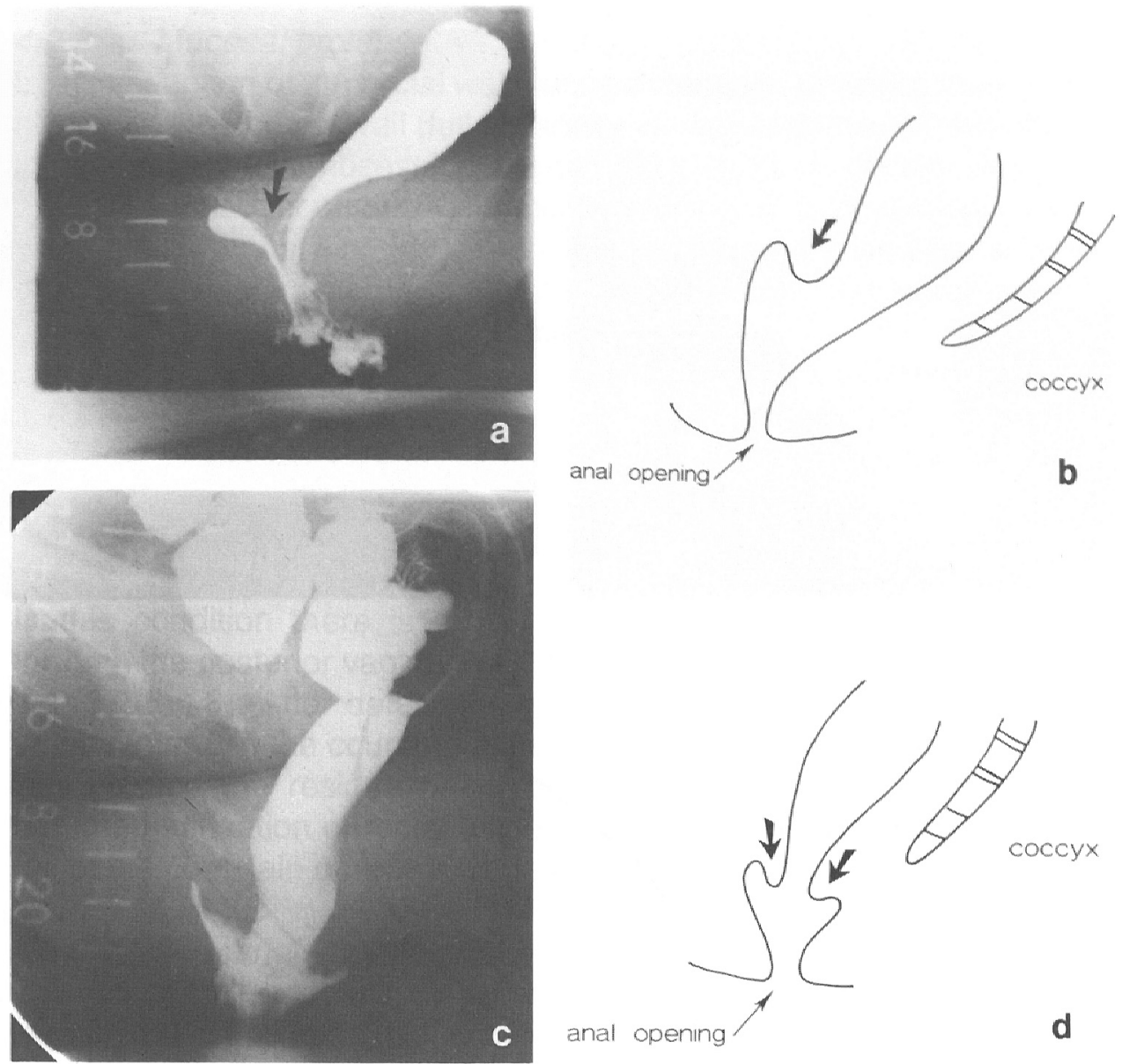

Figure 5. Intraanal rectal intussusception.(a). Infolding of the anterior rectal wall during straining (arrow). (b). Schematic drawing of the anterior wall intraanal rectal intussusception. (c). Circular intraanal rectal intussusception. The entire circumference of the rectal wall folds into the distal rectal lumen. (d). Schematic drawing of the circular intraanal rectal intussusception.

4.3.2 The extraanal rectal intussusception or rectal prolapse When the apex of the intussusception proceeds through the anal opening, the condition is called rectal prolapse (8-10) (Fig.6). While intraanal rectal intussuception is not easy to detect at clinical examination, extraanal rectal intussusception in most cases can be seen clinically. 

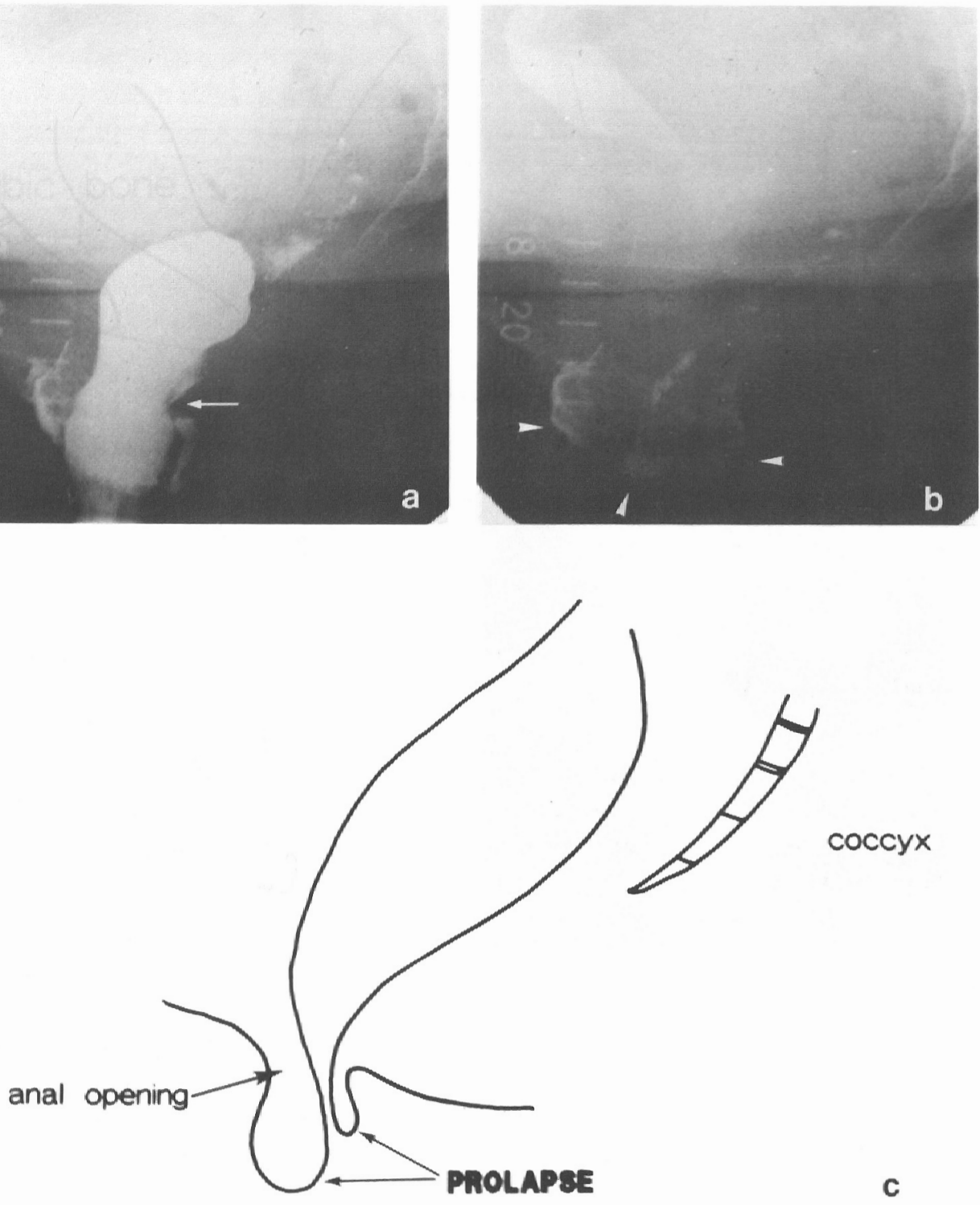

Figure 6. Extraanal rectal intussusception (prolapse). (a) The head of the intussusception protrudes beyond the anal opening (arrow). (b) After the rectal content was evacuated, the prolapse (arrowheads) can be seen hanging beyond the anal opening. (c). Schematic drawing of the rectal prolapse. 


\subsubsection{Mucosal prolapse}

Intussusception of the rectal wall during defecation straining may involve all coats of the bowel wall (full thickness intussusception) or may involve the mucosa only (mucosal prolapse) (11)(Fig.7). A certain degree of mucosal prolapse during defecation straining is a physiologic event, whereby the mucosa prolapses into the rectal lumen or anal canal during the passage of rectal contents. In normal individuals, this is corrected by contraction of the pelvic floor muscles.

Sometimes, however, it appeared to be difficult to differentiate rectal mucosal prolapse from rectal intussusception. In many instances differentiation was based on subjective quantification of anterior rectal wall infoldings.

\subsubsection{Rectocele}

In this condition there is an outpocketing of the anterior rectal wall through the posterior vaginal wall, which occurs during defecation straining (12)(Fig.8). After defecation, residual rectal contents are left in the outpocketing. In the course of time, the contractility of the anterior rectal wall pushes the residue back into the rectal ampulla, resulting in a repeated sensation of rectal fullness. This explains why subjects with a rectocele complain of repeated defecation.

\subsubsection{Descending perineum syndrome}

This condition is caused by the weakening and the lengthening of the levator ani muscles in subjects who have been straining at stool for several years for unknown reasons $(2,13)$. As a result, the laxity of the puborectalis increases, the anorectal angle at rest is straightened out, and there is an abnormal low position of the anorectal junction of more than $4 \mathrm{~cm}$ below the level of the tip of the coccyx (Fig.9). This leads to impairment of the flap valve mechanism of the anorectum, resulting in anal incontinence. Normally, during defecation, the mucosal prolapse is corrected by contraction of the levator ani muscles. When these muscles are weakened,such as in the descending perineum syndrome, the mucosa continues to bulge in the anal canal and prevents further rectal evacuation. Continued straining sets up a vicious circle and eventually, rectal intussusception and rectal prolapse may develop. 

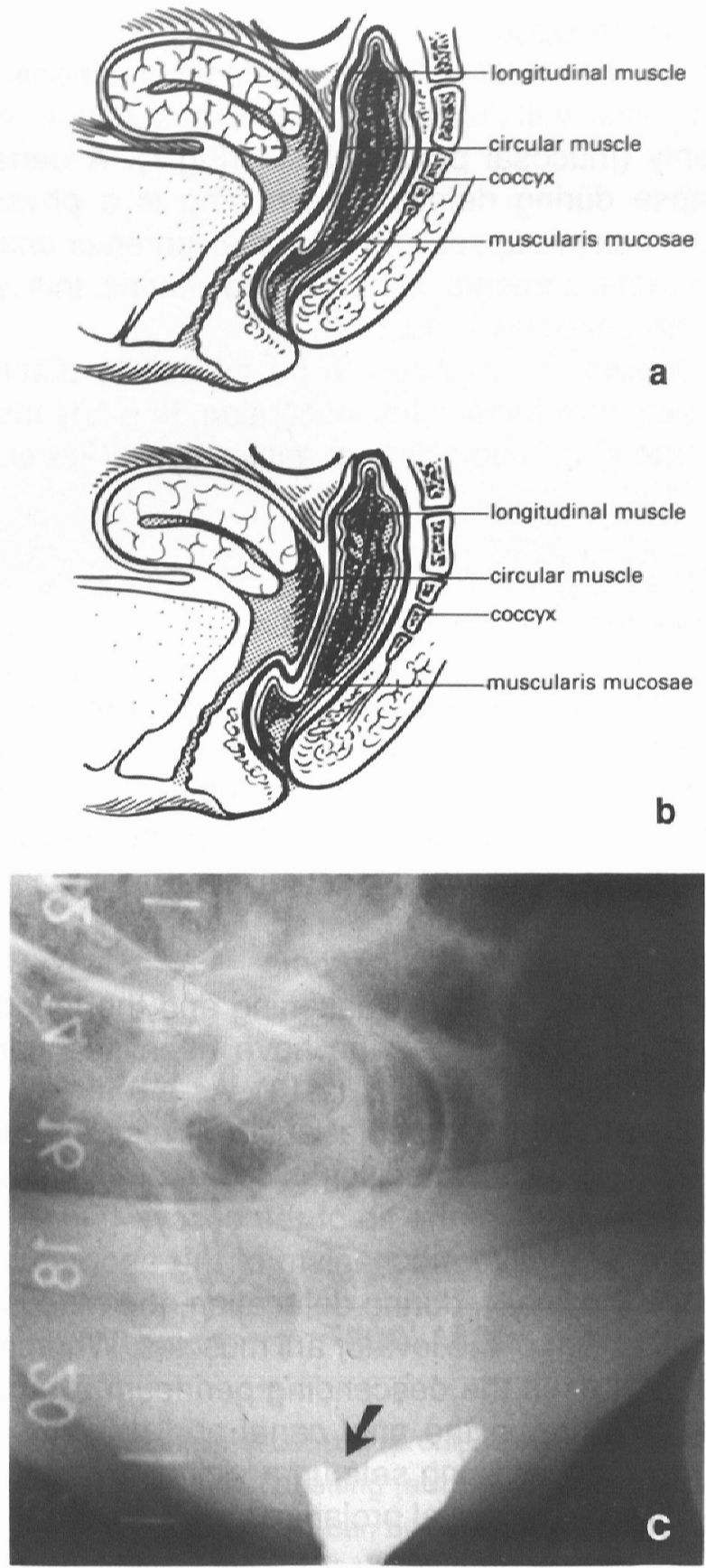

Figure 7. Two different forms of rectal wall intussusception. (a). Schematic drawing of mucosal prolapse. (b). Schematic drawing of full thickness intussusception. (c). Defecogram of mucosal prolapse (arrow). 


\section{a}

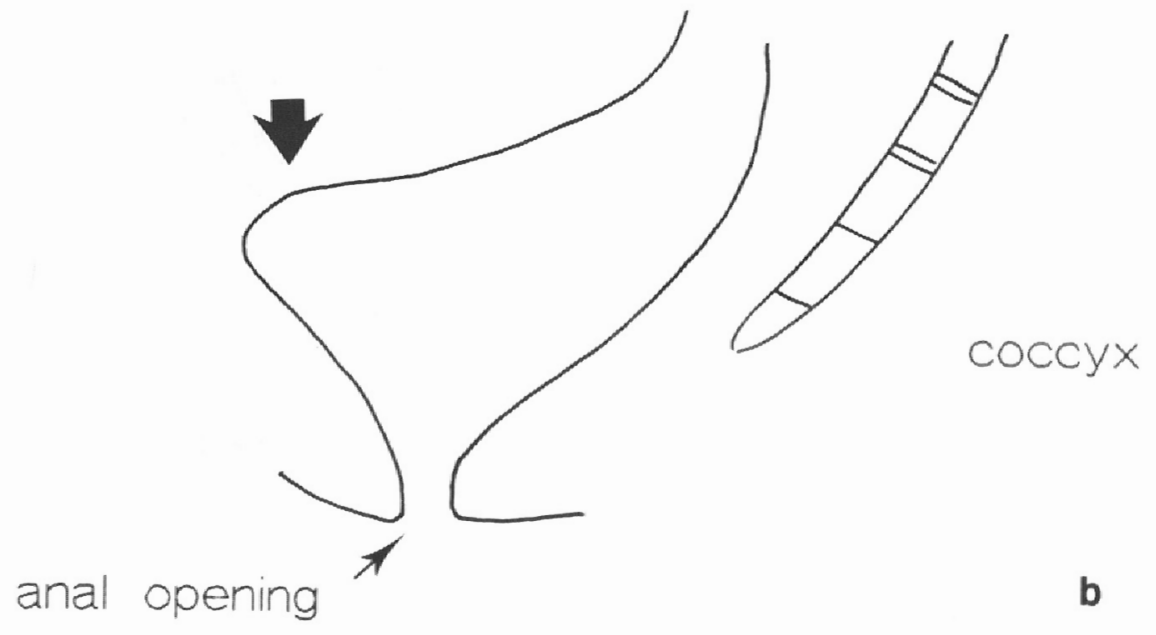

Figure 8. Rectocele. (a). Outpocketing of the anterior rectal wall during defecation straining (arrow). (b). Schematic representation of rectocele. 

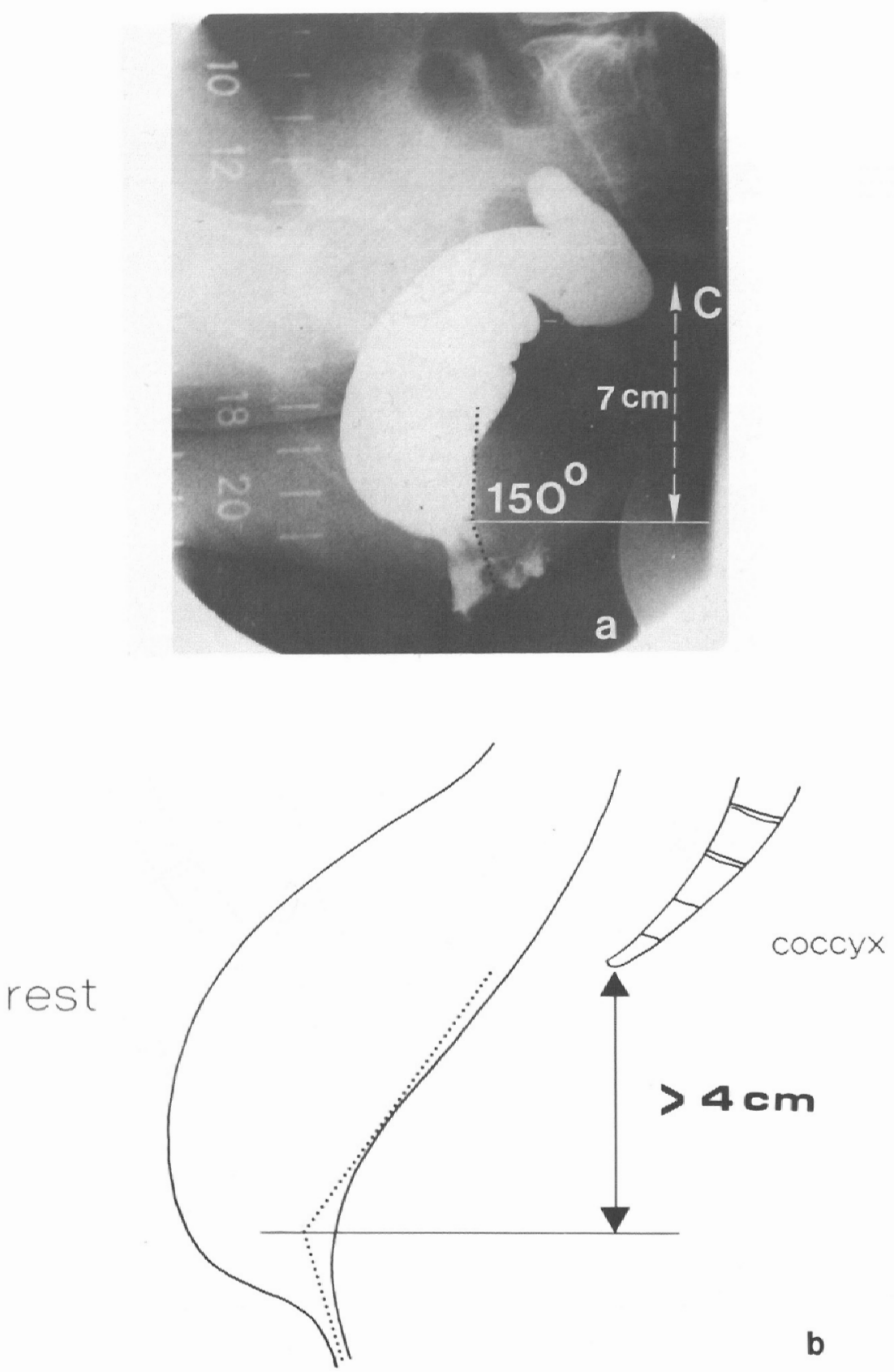

Figure 9. Descending perineum syndrome. (a). At rest, abnormal low position of the anorectal junction of $7 \mathrm{~cm}$ ( 5.5 units of the ruler $\times 1.3$ magnification factor), and obtuse anorectal angulation of $150^{\circ}$ (dotted line). $\mathrm{C}=$ coccyx. (b). Schematic representation of the descending perineum syndrome. 

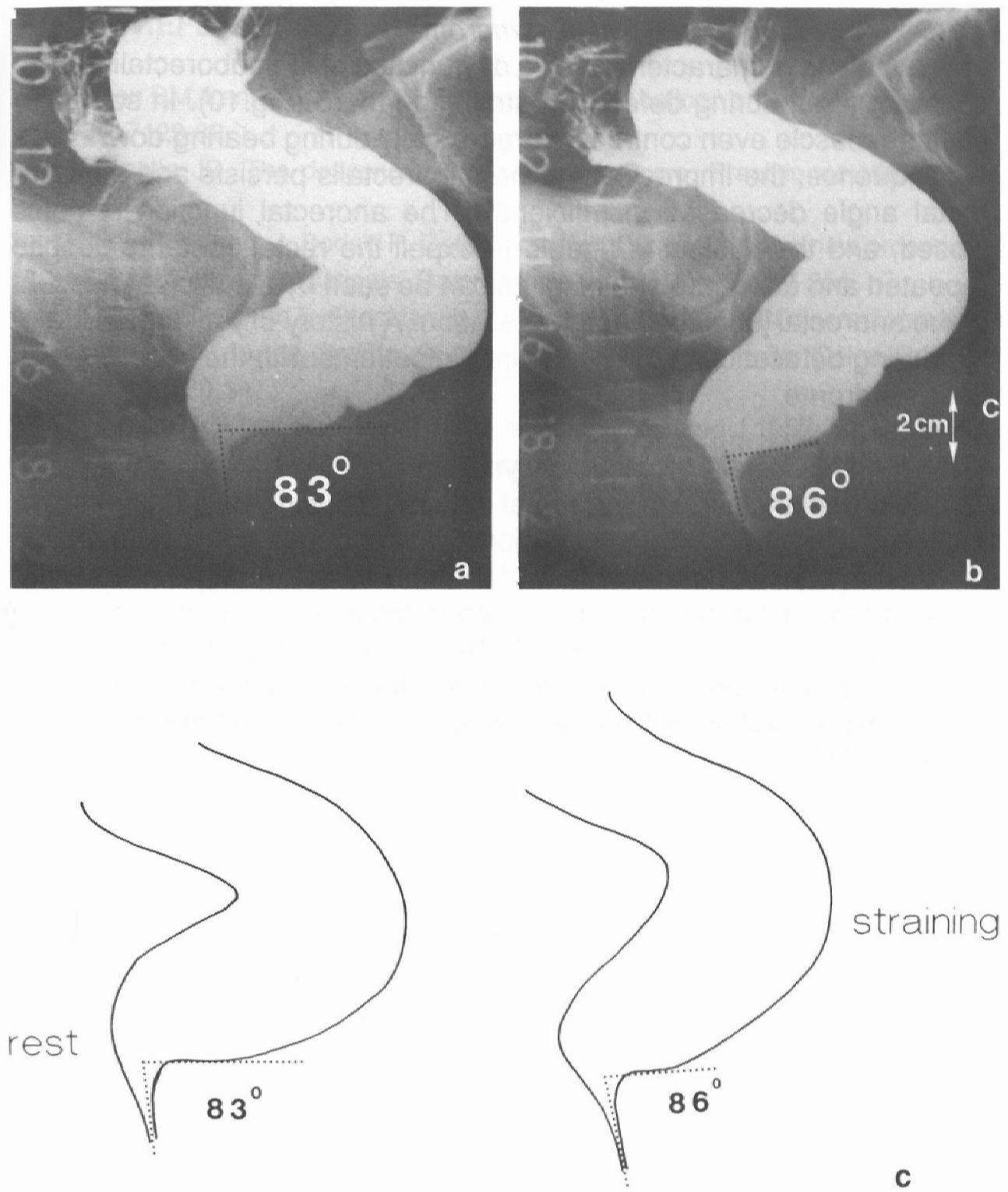

Figure 10. Spastic pelvic floor syndrome. (a) At rest, normal acute anorectal angle of $83^{\circ}$. (b). At straining, nonrelaxation of the puborectalis, resulting in insufficient increase of the anorectal angle, despite adequate straining as can be seen by sufficient descent of the anorectal junction of $2 \mathrm{~cm}$ ( 1.5 units of the ruler $\times 1.3$ magnification factor) (double arrow). Note also absence of opening of the anal canal and no evacuation of contrast material. $\mathrm{C}=$ coccyx. (c). Schematic representation of the spastic pelvic floor syndrome. 


\subsubsection{The spastic pelvic floor syndrome}

This condition is characterized by a dysfunction of the puborectalis which does not relax during defecation straining $(14,15)$ (Fig.10). In some cases, the muscle even contracts paradoxically during bearing down. As a consequence, the impression of the puborectalis persists and the anorectal angle decreases insufficiently. The anorectal junction remains closed, and the subject is unable to expell the rectal contents despite repeated and adequate straining, as can be seen by a sufficient descent of the anorectal junction during defecation. A history of prolonged straining during defecation is often acquired in patients with the spastic pelvic floor syndrome.

\subsubsection{The solitary rectal uicer syndrome}

This is a benign lesion of the rectal mucosa, causing rectal bleeding or mucus discharge, occurring in patients with a long history of defecation disorders (11). Impaired function of the anorectum during defecation is traumatizing to the rectal mucosa and is most likely an important etiologic factor in the development of the lesions. As a dynamic study, defecography is most suitable to detect the underlying functional disorder. This condition will be dealt with extensively in chapter 7 of this thesis. 


\section{REFERENCES}

1. Preston $D_{M}$, Lennard-Jones JE, Thomas BM. The balloon proctogram. Br J Surg 1984; 7: 29-32.

2. Hardcastle JD. The descending perineum syndrome. Practitioner 1969; 203: 612-619.

3. Mahieu $P$, Pringot $J$, Bodart $P$. Defecography.l. Description of a new procedure and results in normal patients. Gastrointest Radiol 1984; 9:247-251.

4. Brodén B, Snellman B. Procidentia of the rectum studied with cineradiography: A contribution to the discussion of causative mechanism. Dis Colon Rectum 1968; 11: 330-347.

5. Asman HB. Internal procidentia of the rectum. South Med J 1957; 50: 641-645.

6. Nigro ND. Procidentia: The etiology of rectal procidentia. Dis Colon Rectum 1972; 15: 330-333.

7. Hoffman MJ, Kodner IJ, Fry RD. Internal intussusception of the rectum. Diagnosis and surgical management. Dis Colon Rectum 1984; $7: 435-441$.

8. Moschkowitz AV. The pathogenesis, anatomy, and cure of prolapse of the rectum. Surg Gyn Obst 1912; 15: 7-20.

9. Theurkauf FJ, Bears $\mathrm{OH}$, Hill JR. Rectal prolapse: Causation and Surgical treatment. Ann Surg 1970; 171:819-835.

10. Ripstein $C B$, Lanter B. Etiology and surgical therapy of massive prolapse of the rectum. Ann Surg 1963; 157: 259-264.

11. Rutter KR, Riddell RH. The solitary ulcer syndrome of the rectum. Clin Gastroenterol $1975 ; 4: 505-530$.

12. Mahieu P. Pringot J, Bodart P. Defecography: Il. Contribution to the diagnosis os defecation disorders. Gastrointest Radiol 1984; 9: 253-261.

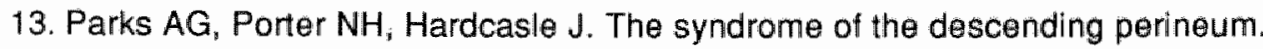
Proc Roy Soc Med 1966; 59: 31-36.

14. Wasserman IF. Puborectalis syndrome (rectal stenosis due to anorectal spasm). Dis Colon Rectum 1964; 7: 87-98.

15. Kuypers $H C$, Bleyenberg $G$. The spastic pelvic floor syndrome: a cause of constipation. Dis Colon Rectum 1985; 28: 669-672. 



\section{Chapter 5}

\section{ANORECTAL FUNCTION \\ Defecographic measurement in asymptomatic subjects}

Reginald Goei, MD; Jos van Engeishoven, MD; Hubert Schouten, PhD; Cor Baeten,MD; Chrit Stassen MD.

Radiology 1989; 173:137-141.

\section{ABSTRACT}

A study of anorectal function during fluoroscopically monitored defecation was conducted in 32 asymptomatic subjects. Two observers independently measured various parameters on the defecograms and reviewed the video recordings during the subjects' squeezing, rest and straining. There was a wide range of measurements for the anorectal angle, the position of the anorectal junction, perineal motility and anal canal width. Interobserver variation of these measurements was large. In 17 subjects, both observers agreed that rectal emptying was incomplete. In 10 patients, there was agreement on the presence of rectal wall changes such as intussusception, rectocele and mucosal prolapse. Defecographic measurements should be interpreted with caution and should not be used as the only criteria for treatment. Anatomic changes of the anorectal region during straining at defecation do not necessarily cause symptoms, whether they will develop into a clinically manifested disorder needs further investigation. 


\section{INTRODUCTION}

The earliest publication on the radiologic study of the mechanism of defecation originated in 1952 from Lennart Walldén, who extensively investigated the role of an abnormally deep pouch of Douglas on the disturbed mechanism of defecation (1). Although several authors since then have described the importance of defecography in the evaluation of evacuation difficulties including straining at evacuation at stool, faecal incontinence, sensation of incomplete evacuation and discharge of mucus it remained a specialized technique that did not become incorporated into routine clinical practice. Improvements and refinements in proctologic surgical techniques brought about new interest in the study of anorectal functional disorders. Several reports (2-4) described the various pathologic conditions found at evacuation studies in symptomatic patients; although there are also some studies on anorectal function in healthy subjects (4-8), these investigations cannot be adequately compared because of the various definitions given to the different measurement criteria. As yet, understanding is still lacking of the normal pattern and variants of the dynamics of the anorectum.

The purpose of the present investigation was to analyze the function of the anorectal region radiologically in subjects without defecatory disorders and to provide a baseline for the study of abnormal function.

\section{SUBJECTS AND METHODS}

From December 1987 to September 1988, 32 patients referred for barium enema examination, were studied. For radiation protection of younger individuals, only those older than 41 years of age were investigated. There were 19 males and 13 females with a mean age of 58 years (range 41-71 years). Before entry into the study a detailed history was obtained from each patient and the presence of bowel dysfunction was noted. Subjects with macroscopic rectal bloodloss, discharge of mucus, straining at evacuation at stool, incomplete evacuation, faecal incontinence or a history of previous pelvic surgery were excluded. Of 625 referrals for barium enema, 36 subjects met all criteria for inclusion and were asked to participate in the study; four refused to undergo defecography. Indications for barium enema were an episode of abdominal discomfort, weight loss or elimination of a diagnosis of malignancy. All 32 
patients gave their informed consent for the study, which was approved by the Ethical Committee of the Hospital Board. Defecography was performed before the barium enema study with our previously described standardized technique (9). After the subject underwent the necessary preparation for the double contrast barium enema study, $300 \mathrm{ml}$ of a thick barium paste with the consistency of feces was injected manually via a syringe through a Miller air tip (E-Z-EM, Westbury, NY) into the rectum, with the patient lying on the left side. After changing to a sitting position on a specially designed seat, the function of the anorectal region was studied under fluoroscopy in lateral projection and the entire procedure was recorded on a Sony U-Matic videotape (Sony Corporation, Atsugi, Japan). (To minimize the radiation dose the number of exposures were limited to three with the use of a $105 \mathrm{~mm}$ camera). The recording was made during squeezing, whereby the patient was asked to contract the pelvic floor muscles maximally; at rest, when the pelvic floor muscles were completely relaxed; and during straining, at maximum distension of the anal canal. The video recording was ended when rectal evacuation had stopped, despite repeated defecation straining.

To determine the interobserver variation the video recordings and the barium studies were analyzed independently by two observers experienced in the interpretation of defecograms. During the successive stages of defecation, the following parameters were considered: (a) The anorectal angle, which represents the angle between the axis of the anal canal and a line along the lower posterior border of the distal part of the rectum (Fig.1a). (b) The position of the anorectal junction (ARJ) with respect to the level of the tip of the coccyx (the point at which the lines of the anorectal angle intersected was defined as the anorectal junction) (Fig.1). (c) The elevation of the anorectal junction from rest to squeezing and its descent from rest to straining. (d) The maximal width of the anal canal. (e) The completeness of rectal emptying; and (f) The morphologic changes of the rectal wall (Fig.2).

Measurements of the distances were made by reference to a radiopaque ruler placed in the center of the seat.

For statistical analysis of the quantitative data, the method described by Bland and Altman (10) was applied. Differences between the two observers was plotted against mean values (Fig.3). The mean and standard deviation of a variable were based on the average value of the two observers. 

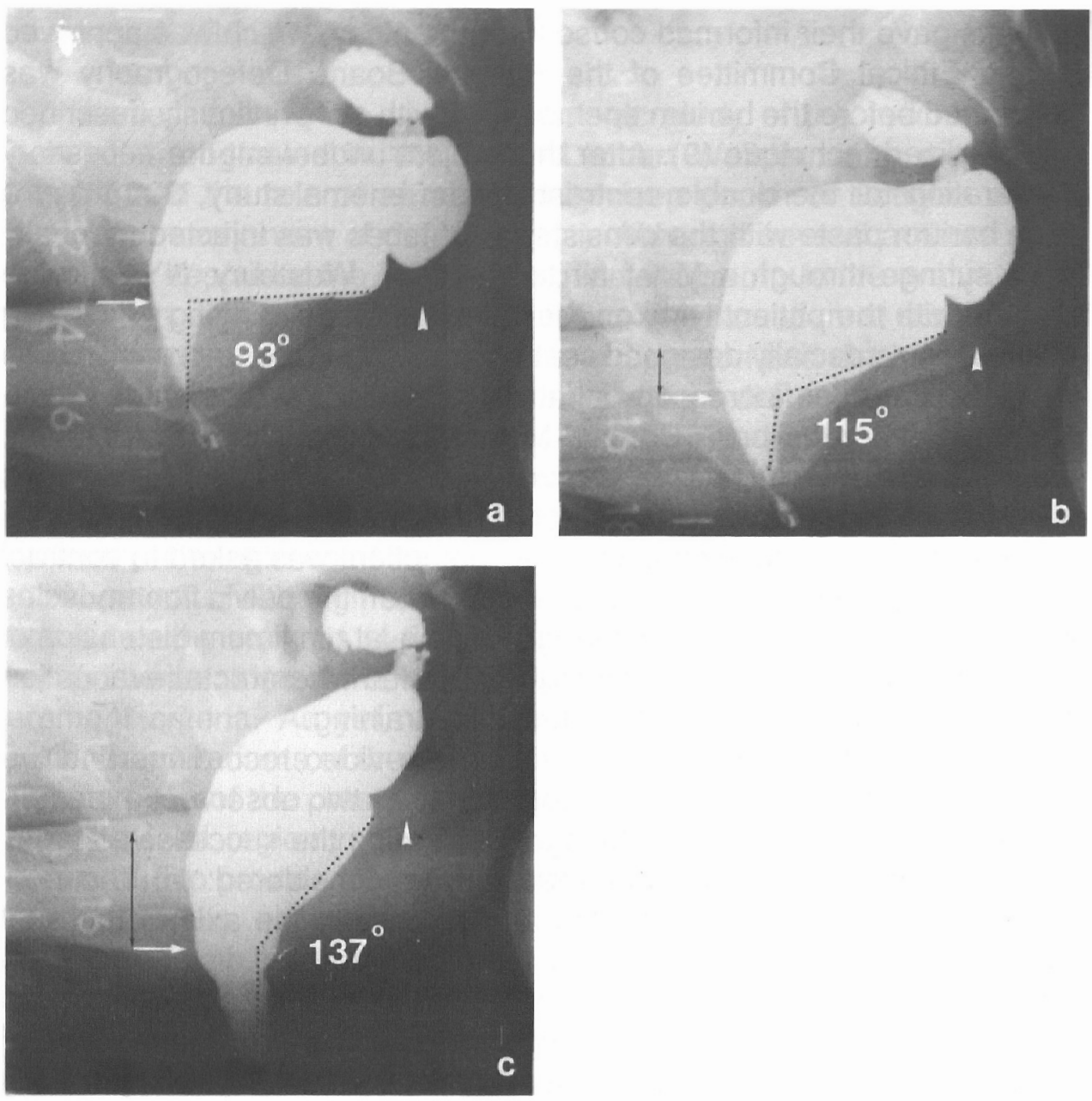

Figure 1. Normal defecogram. (a). During squeezing the anorectal angle measured $93^{\circ}$ (dotted line), and the anorectal junction (arrow) was near the level of the tip of the coccyx (arrowhead). (b). At rest the anorectal angle was $115^{\circ}$ (dotted line) and the anorectal junction (arrow) was $1.7 \mathrm{~cm}(1.2$ units of the ruler $\times 1.4$ magnification factor)(double ended arrow) below the tip of the coccyx (arrowhead). (c). During straining the anorectal angle (datted line) widened to $137^{\circ}$ and the anorectal junction (arrow) descended to $4.2 \mathrm{~cm}$ ( 3.0 units of the ruler $\times 1.4$ magnification factor) (double ended arrow) below the tip of the coccyx (arrowhead). 

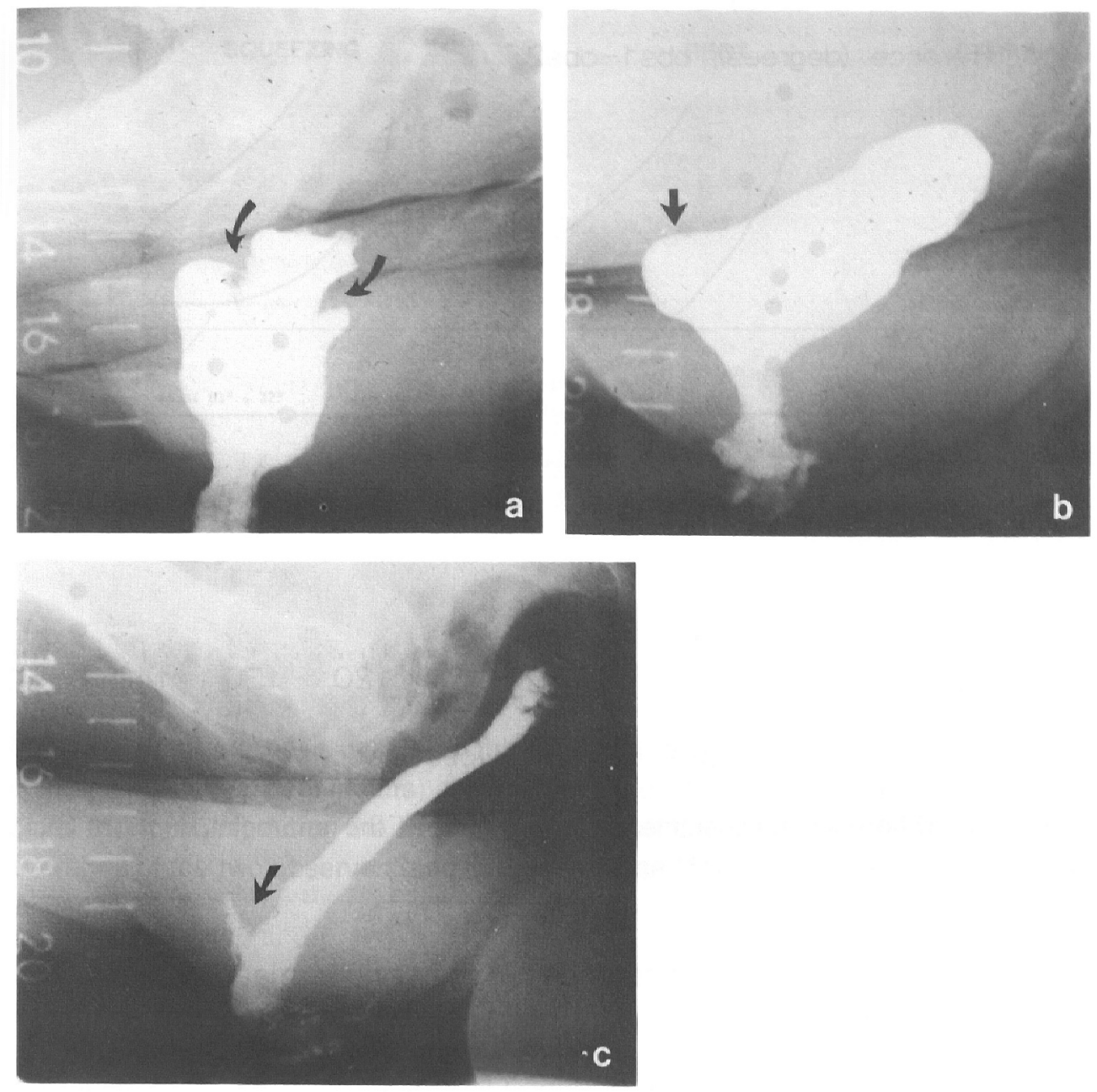

Figure 2. Defecograms of rectal wall changes during straining. (a). Annular intussusception of the proximal rectal wall into its distal lumen (arrows). (b). Outpocketing of the anterior rectal wall forms a rectocele (arrow). (c). Slight infolding at the anterior rectal wall represents a mucosal prolapse (arrow). 


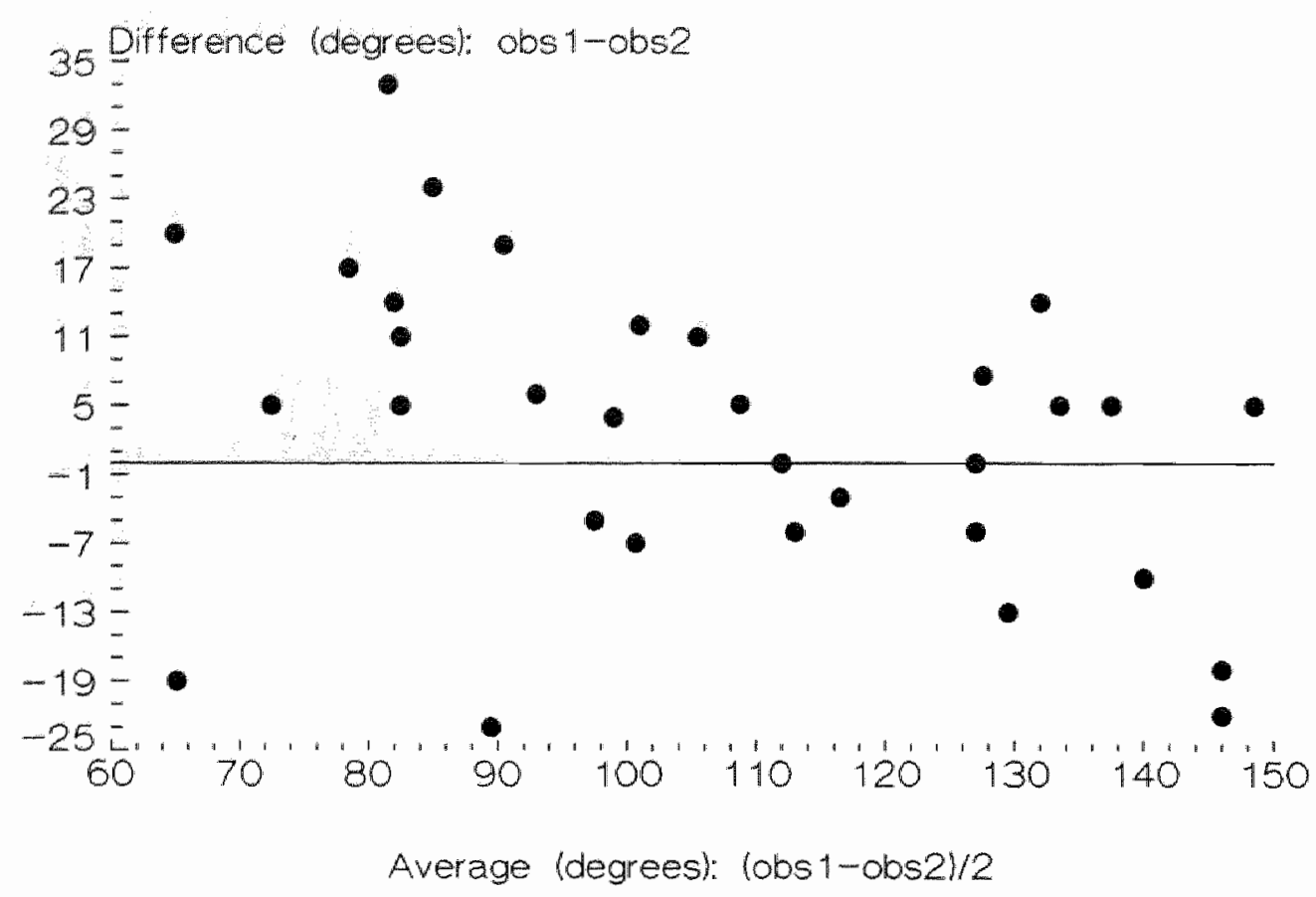

Figure 3. Difference against mean for the data of the anorectal angle at rest, measured by observer 1 (obs 1) and observer 2 (obs2)

Statistical analysis of the differences in the various measurements between sexes was performed with the Wilcoxon rank sum test for independent samples. The results were defined as statistically significant when the level of significance ( $p$-value) was less than .01 .

In the absence of an absolute standard the kappa statistic was used to measure the agreement of the categorical data with a correction for chance (11). The kappa value was calculated with the following formula: kappa $=(\mathrm{pO}-\mathrm{pc}) /(1-\mathrm{pc})$, where $\mathrm{pO}$ is the observed proportion of agreement and pc is the proportion expected by chance (Table 1). Kappa can range from -1 to +1 , and the rating by Fleiss (12), which characterizes the strength of agreement was used: kappa $\leq 0.40=$ poor, $0.40-0.75$ = fair to good and $\geq 0.75$ = excellent agreement beyond chance. 


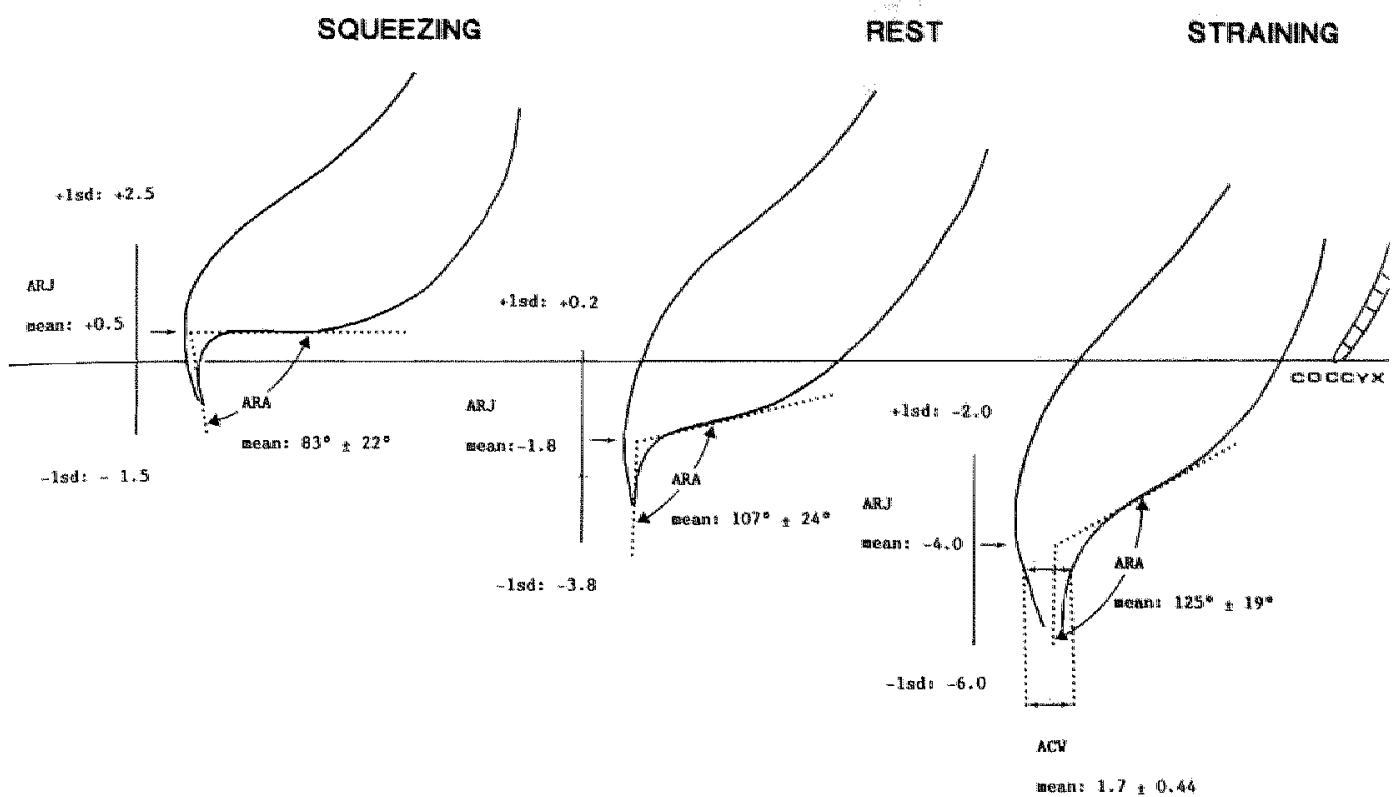

Figure 4. Diagram shows position of the anorectal junction (ARJ) with respect to the tip of the coccyx (in centimeters) and values of the anorectal angle (ARA) and anal canal width (ACW) during the successive stages of defecation. All values were the averages of the two observers and thus represented the best estimates of the true values.

\section{RESULTS}

Figure 3 shows a wide interobserver variation of the anorectal angle at rest. Although not shown, graphs of the remaining quantitative data showed similar data. The values of the various parameters are presented in Figure 4 and Tables 3 and 4.

Anorectal angle

At squeezing, the mean ( \pm the standard deviation [SD]) of the anorectal angle was $83^{\circ} \pm 22^{\circ}$; at rest the angle widens to a mean of $107^{\circ} \pm 19^{\circ}$, and at straining a further increase to $125^{\circ} \pm 24^{\circ}$ was measured (Fig.4). In 27 out of 32 subjects the ARA widened from rest to straining with a mean of $24^{\circ} \pm 19^{\circ}$. In five subjects, the angle decreased paradoxically, with a mean of $19^{\circ} \pm 13^{\circ}$. There was fair to good agreement between the 
Table 1. Calculation of Kappa Value for Rectal Emtying

\section{Observer 2}

\begin{tabular}{lcll} 
Observer 1 & Insufficient & Sufficient & Total \\
\hline Insufficient & 17 & 2 & 19 \\
Sufficient & 9 & 4 & 13 \\
Total & 26 & 6 & 32 \\
\hline
\end{tabular}

Note. - Kappa $=0.24$. Calculation was based on the following formulas: $p O=(a+d) / n, p c=(a+b)(a+c) / n^{2}+(b+d)(c+d) / n^{2}$, and kappa $=(p O-p c) /(1-$ pc), where $a=$ insufficient by both observers, $b=$ insufficient by observer 1 and sufficient by observer $2, c=$ sufficient by observer 1 and insufficient by observer 2 , and $\mathrm{d}=$ sufficient by both observers.

Table 2. Calculation of Kappa Value for Abnormalities of the Rectal Wall

Observer 2

\begin{tabular}{lccc}
\cline { 2 - 3 } Observer 1 & Abnormal & Normal & Total \\
\hline Abnornal & 10 & 3 & 13 \\
Normal & 2 & 17 & 19 \\
Total & 12 & 20 & 32
\end{tabular}

Note.- Kappa $=0.66$. Calculation was based on the formulas listed in footnote to Table 1 , with $\mathrm{a}=$ abnormal by both observers, $\mathrm{b}=$ abnormal by observer 1 and normal by observer $2, c=$ normal by observer 1 and abnormal by observer 2 , and $d$ $=$ normal by both observers. 
Table 3. Change in Anorectal Angle during Defecation in 32 Subjects.

\begin{tabular}{llllclc}
\hline Stage of Defecation & $\begin{array}{l}\text { Mean } \pm \text { SD } \\
\text { (degrees) }\end{array}$ & $\begin{array}{l}\text { Range } \\
\text { (degrees) }\end{array}$ & $\begin{array}{l}\text { Increased } \\
\text { ARA }\end{array}$ & $\begin{array}{l}\text { Decreased } \\
\text { ARA }\end{array}$ & $\begin{array}{l}\text { Kappa } \\
\text { Value }\end{array}$ \\
\hline From rest to straining & $17 \pm 24$ & -30 to 80 & 27 & 5 & 0.57 \\
From rest to squeezing & $23 \pm 19$ & -4 to 69 & 2 & 30 & -0.30 \\
\hline
\end{tabular}

Note. - ARA $=$ anorectal angle. Negative values denote decrease in ARA. Positive values denote increase in ARA.

Table 4. Change in Excursion of the Anorectal Junction during Defecation in 32 Subjects

\begin{tabular}{llllll}
\hline Stage of defecation & $\begin{array}{l}\text { Mean } \pm \mathrm{SD} \\
(\mathrm{cm})\end{array}$ & $\begin{array}{l}\text { Range } \\
(\mathrm{cm})\end{array}$ & $\begin{array}{l}\text { AR」 } \\
\text { Descent }\end{array}$ & $\begin{array}{l}\text { ARJ } \\
\text { Ascent }\end{array}$ & $\begin{array}{l}\text { Kappa } \\
\text { Value }\end{array}$ \\
\hline From rest to strainig & $2.4 \pm 1.8$ & -7.5 to 0.1 & 29 & 3 & 0.47 \\
From rest to squeezing & $2.3 \pm 1.4$ & $0.1-5.4$ & 0 & 32 & 0 \\
\hline
\end{tabular}

Note.- ARJ = anorectal junction. Negative values denote descent of ARJ. Positive values denote ascent of ARJ.

observers (Kappa: 0.57) (Table 3). From rest to squeezing, 30 subjects showed a decrease of the anorectal angle according to both investigators, and the mean was $25^{\circ} \pm 19^{\circ}$. In two subjects an increase of the anorectal angle was measured; however, the observers disagreed in these 2 cases and therefore kappa was negative (Table 3).

\section{Anorectal junction}

At squeezing, the anorectal junction was $0.5 \pm 2.0 \mathrm{~cm}$ above the level of the tip of the coccyx, its position at rest was $1.8 \pm 2.0 \mathrm{~cm}$ below this level, and during straining at defecation there was a further descent to $4.0 \pm$ $2.0 \mathrm{~cm}$ below the point of reference (Fig.4). 
Table 5. Differences in Defecographic Measurements between Sexes

\begin{tabular}{lrr}
\hline Measurements & \multicolumn{1}{c}{$\begin{array}{l}\text { Men } \\
(n=19)\end{array}$} & $\begin{array}{r}\text { Women } \\
(\mathrm{n}=13)\end{array}$ \\
\hline Anorectal angle (degrees) & & \\
At squeezing & $81 \pm 23$ & $86 \pm 20$ \\
At rest & $104 \pm 25$ & $112 \pm 23$ \\
At straining & $122 \pm 22$ & $129 \pm 11$ \\
From rest to straining & $16 \pm 25$ & $19 \pm 24$ \\
From rest to squeezing & $22 \pm 20$ & $25 \pm 19$
\end{tabular}

Anorectal junction (cm)

$\begin{array}{lcc}\text { At squeezing } & 0.7 \pm 2.1^{\star} & 0.3 \pm 1.8^{*} \\ \text { At rest } & -1.7 \pm 2.4^{+} & -1.8 \pm 1.8^{+} \\ \text {At straining } & -3.6 \pm 2.5^{+} & -4.5 \pm 1.5^{+} \\ \text {From rest to straining } & 2.4 \pm 1.8 & 2.6 \pm 2.0 \\ \text { From rest to squeezing } & 2.5 \pm 1.5 & 2.1 \pm 1.3\end{array}$

Anal canal with $(\mathrm{cm})$

At squeezing

0

At straining
0

$1.7 \pm 0.4$

0

0

$1.8 \pm 0.4$

Note.- Numbers represent mean $\pm \mathrm{SD}$. The Wilcoxon rank sum test for independent samples was used for analysis. All P values were insignificant. " Position above the level of the tip of the coccyx. + Position below the level of the tip of the coccyx.

\section{Perineal excursions}

On maximally contraction of the pelvic floor muscles, both observers agreed that all subjects showed an elevation of the anorectal junction (mean, $2.3 \mathrm{~cm} \pm 1.4$ ). Because none of the observers measured a descent of the anorectal junction during squeezing kappa was 0 (Table 4). On complete relaxation of the muscles during bearing down, the perineum descended, with a mean of $2.0 \pm 1.8 \mathrm{~cm}$ in 29 subjects, whereas it elevated paradoxically in 3 subjects, with a mean of $0.3 \mathrm{~cm} \pm$ 0.2 and fair to good agreement between the observers (Kappa $=0.47$ ) (Table 4). 
Table 6. Independent classification of the rectal wall changes by two observers

Subject No. / Sex Observer $1 \quad$ Observer 2

\begin{tabular}{lll}
\hline $1 / \mathrm{M}$ & intussuception & mucosal prolapse \\
$2 / \mathrm{M}$ & intussusception & intussusception \\
$3 / \mathrm{M}$ & intussusception & mucosal prolapse \\
$4 / \mathrm{F}$ & intussusception & intussusception \\
$5 / \mathrm{F}$ & rectocele & rectocele \\
$6 / \mathrm{M}$ & intussusception & intussusception \\
$7 / \mathrm{F}$ & rectocele & rectocele \\
$8 / \mathrm{F}$ & intussusception & mucosal prolapse \\
$9 / \mathrm{F}$ & rectocele & rectocele \\
$10 / \mathrm{F}$ & intussusception & intussusception \\
\hline
\end{tabular}

\section{Anal canal width}

During squeezing and at rest, the anal canal was closed in all subjects according to both observers. They found an open anal canal during maximally straining in all subjects (mean, $1.7 \mathrm{~cm} \pm 0.4$ )(Fig.4).

Table 5 shows no statistically significant differences in the various measurements between sexes.

\section{Rectal evacuation}

In four subjects, there was agreement between the observers on complete rectal emptying (Table 1). Seventeen subjects showed incomplete evacuation, according to both investigators, and there was disagreement in 11 cases. The kappa value for the sufficiency of rectal emptying was 0.24 , indicating poor agreement between the observers.

\section{Morphological Changes of the Rectal Wall}

In 10 patients (four men, six women) with abnormalities of the rectal wall, there was agreement between the observers (Table 2). The data resulting from their classifications are listed in Table 6. In 17 subjects, observers agreed on the absence of changes and in the remaining five there was disagreement. The kappa value for the absence or presence of anatomical changes of the shape of the rectal wall was 0.66 , a representation of good agreement between the investigators. 


\section{DISCUSSION}

In the mechanism of defecation and the maintenance of anal continence, the pelvic floor muscles play a primary role; the anorectal angle reflects the physiology of these muscles. Hardcastle (13) studied the size of the angulation in healthy individuals and found an average of $84^{\circ}$. Recently Skomorowska et al. (5) measured the anorectal angle in asymptomatic subjects aged 27-74 years and found mean values at rest of $108^{\circ}$ in women and $127^{\circ}$ in men. Bartram et al. (6) stated that at rest the anorectal angle was $115^{\circ} \pm 17^{\circ}$. Shorvon et al. (7) investigated young healthy volunteers of $19-35$ years of age and reported a range of $64^{\circ}$ $125^{\circ}$ for men and $70^{\circ}-134^{\circ}$ for women.

The differences in the measurements reported by these authors are partially due to the differences in defining the anorectal angle.

In the present study a mean angulation of $107^{\circ} \pm 24^{\circ}$ and a range from $65^{\circ}$ to $146^{\circ}$ was found in individuals of both sexes which were free of defecatory disorders in the age group between 41 years and 71 years. Thus, our findings are in agreement with those in previous studies that show a wide variation of the anorectal angle at rest in healthy individuals. Although there were differences of the means and SDs of the various parameters between men and women, these were not statistically significant (Table 5).

Figure 3 shows a large interobserver variability, notwithstanding the uniformity of the method of measurement. Controversy exists regarding changes in the anorectal angle during the successive stages of defecation. Some authors $(6,8)$ have stated that the anorectal angle widens during straining; however, in this study, the angulation decreased in $16 \%$ of the subjects (Table 3). This indicates nonrelaxation of the pelvic floor muscles during defecation. During squeezing, the puborectalis contracts, which results in a decrease of the anorectal angle. This event was noted by both observers in $94 \%$ of subjects. In two of 32 subjects, the observers completely disagreed: In one patient, observer 1 measured an increase of the anorectal angle, and observer 2 measured a decrease. In the other patient, observer 1 measured a decrease of the angulation and observer 2 measured an increase. Because the observers used the category of increase in only these two subjects, the kappa value was negative and the actual agreement was not larger than expected by chance. The agreement on the category of decrease was large simply because this phenomenon occurred in the majority of subjects. It can 
therefore be stated that during squeezing the anorectal angle always decreased, and that the increases of the anorectal angle in both cases probably were the result of exceptional errors of measurements.

The large variation of the position of the anorectal junction and the amount of its descent during defecation straining in our study, are in concordance with those observed by other investigators (5-7).

In many reports, the pubococcygeal line or the ischial tuberosities were used as the point of reference, but measurements of perineal excursions relative to the level of the tip of the coccyx proved to be easier. Although these bony landmarks were used as relative reference points, discrepancies exist between measurements of motion in this study and those mentioned in the literature. These differences are most likely caused by the different age groups studied by the several investigators. In subjects aged 19-35 years, who were studied by Shorvon et all (7), perineal descent ( $19.7 \mathrm{~mm} \pm 9.1$ for men and $20.0 \mathrm{~mm} \pm 14.6$ for women) was less than in the age group between $41-71$ years in this study $(2.4 \mathrm{~cm} \pm$ 1.8). This is probably a result of increased laxity of the pelvic floor muscles in older subjects.

However, a position of the anorectal junction at rest lower than $\pm 4 \mathrm{~cm}$ below the level of the tip of the coccyx (Fig.4) and/or a descent of more than $\pm 4 \mathrm{~cm}$ during straining (Table 4 ) should be considered pathologic. This condition is a result of weakening and increased laxity of the puborectalis after a long period of straining at evacuation of stool. The condition may lead to incontinence and is a predisposing factor in the development of rectal prolapse (14).

In opposition to the observations by Shorvon (7), who found an open anal canal in $7 \%$ of healthy individuals, in our investigation both observers completely agreed that the anal canal was closed at rest in all patients. During defecation, the iliococcygeus and the pubococcygeus contracts. The anal canall opens and widens as a result of the lateral pull exerted by these muscles. This was observed by both investigators in all of our subjects.

Although the patients were instructed to evacuate completely, there was agreement between the observers that 17 out of 32 subjects, who did not have a sensation of incomplete evacuation, showed residual contrast material in the rectum. We think that after most of the rectal contents was expelled, decreased distension of the rectal wall abolished the sensation of rectal fullness of the perineum and of further need to defecate. It is most unlikely that the cleansing regimen affected rectal evacuation. 
The poor agreement between the observers concerning rectal emptying indicated that visual assesment of this parameter was unreliable. This was a result of the difficulty in determining whether the contrast material left in the rectum was due to mucosal coating or residue.

It is remarkable that changes in rectal shape during straining were not mentioned in several studies on anorectal motility in healthy subjects $(5,8)$. This investigation, however, confirmed the observations made by Bartram et al $(6,7)$, who noted that anatomic abnormalities of the rectal wall, such as intussusception, rectocele and mucosal prolapse occur in asymptomatic subjects. Although there was agreement between the observers about the presence of rectal wall abnormalities, there were discrepancies in their classification as mucosal prolapse or intussusception (Table 6). Differentiation between these conditions appeared to be difficult and was based on subjective quantification of the anterior rectal wall infoldings.

We agree with Berman et al (15) that demonstration of rectal wall changes in the absence of defecatory disorders is of no greater importance than accidental demonstration of esophageal hiatal hernia.

In our opinion, the current study supports and extends the conclusion of previous investigations that there is a large variation in the patterns of anorectal function among healthy individuals. There is also a large interobserver variation in the measurements of some of the parameters of anorectal function. Therefore, caution should be taken when these measurements are interpreted, and the measurements should not be used as the only criteria for treatment. Changes in the shape of the anorectal region during defecation should be considered abmormal. However, these changes do not necessarily cause symptoms. Whether they will progress in a clinically manifested disorder needs further investigation. 


\section{REFERENCES}

1. Walldén L. Defecation block in cases of deep rectogenital pouch. Acta Chir Scan 1952; supplementum 165: 1-121.

2. Broden $B_{n}$ Snellman $B$. Procidentia of the rectum studied with cineradiography: a contribution to the discussion of causative mechanism. Dis Colon Rectum 1968; 11: 330-347.

3. Mahieu P, Pringot J. Bodart P. Defecography: II. Contribution to the diagnosis of defecation disorders. Gastrointest Radiol 1984; 9:253-261.

4. Ekberg O, Nylander G, Fork FT. Defecography. Radiology 1985; 155:45-48.

5. Skomorowska E, Henrichsen S, Christiansen J, HegedÜs V. Acta Radiologica 1987; 28: 559-562.

6. Bartram $\mathrm{Cl}$, Turnbull GK, Lennard-Jones JE. Evacuation Proctography: An Investigation of Rectal Expulsion in 20 Subjects Without Defecatory Disturbance. Gastrointest Radiol 1988; 13: 72-80.

7. Shorvon P, Stevenson GW, Mc Hugh S, Somers S. Defecography: A study of normal volunteers. Radiology 1987; 165 (P) Supplement: 428 (abstract of Scientific Exhibit).

8. Mahieu P, Pringot J, Bodart P. Defecography: I. Description of a new procedure and results in normal patients. Gastrointest Radiol 1984; 9: 247-251.

9. Goei R, Baeten C, Arends JW. Solitary Rectal Ulcer Syndrome: Findings at Barium Enema Study and Defecography. Radiology 1988; 168: 303-306

10. Bland JM, Altman DG. Statistical methods for assessing agreement between two methods of clinical measurement. The Lancet 1986; 1: 307-310.

11. Sacket DL, Brian Haynes R, Tugwell P. Clinical Epidemiology. A Basic Science for Clinical Medicine. Chapter 2. Little, Brown and Company, Boston / Toronto $1985 ; 22-31$.

12. Fleiss JL. Statistical Methods for Rates and Proportions. Page 218. Wiley, New York 1985.

13. Hardcastle JD. The descending perineum syndrome. Practitioner 1969; 203: 612-619.

14. Porter NH. A physiological study of the pelvic floor in rectal prolapse. Ann Roy Coll Surg 1962; 31: 379-403.

15. Berman IR, Manning DH, Dudley-Wright K. Anatomic Specificity in the Diagnosis and Treatment of Internal Rectal Prolapse. Dis Colon Rectum 1985; 28: 816826. 



\section{Chapter 6}

\section{ANORECTAL FUNCTION IN PATIENTS WITH DEFECATION DISORDERS AND ASYMPTOMATIC SUBJECTS Evaluation with defecography}

Reginald Goei, MD

Radiology 1990;174:121-123

\section{ABSTRACT}

A controlled radiologic study of anorectal function was performed with the use of defecography in 19 patients with constipation and 13 with incontinence. All patients were age and sex matched to control subjects who were referred for barium enema study and who had no defecation disorder. There were no statistically significant differences between either patient group and the control group in anorectal angle and excursion of the anorectal junction.

In the 32 patients and 155 consecutive patients referred for defecography because of a variety of defecation disturbances, approximately twice as many rectal wall abnormalities were seen compared with findings in the control group. These findings included intussusception, prolapse, rectocele, mucosal prolapse, spastic pelvic floor, descending perineum syndrome, and solitary rectal ulcer syndrome. In conclusion, the main role of defecography is to document rectal wall changes during defeca- 
tion straining as possible causes of evacuation difficulties. Clinical symptoms should also be taken into account when treatment is contemplated.

\section{INTRODUCTION}

In recent years, interest in anorectal functional disorders as a cause of constipation and fecal incontinence has been renewed. Several publications have appeared on the radiologic depiction of abnormalities of the anorectum during evacuation of contrast material in patients with defecation disorders $(1-5)$. The intention of these studies was to describe the findings at defecography in a single group of symptomatic patients, and, to our knowledge, no comparative study with control subjects have been reported in the literature.

It is obvious from a previous study (6), and from studies of other investigators that there is a wide range of variations in the anorectal function in asymptomatic subjects, and that abnormalities of the rectal wall during defecation straining occurred in approximately $30 \%$. (6-9).

Therefore, the question can be raised as to whether and to what extent anorectal function in patients with defecation disturbances differs from that in asymptomatic subjects.

To answer this question, the dymamics of the anorectum was studied in patients and compared with a control group that was matched for age and sex.

\section{PATIENTS AND METHODS}

During a 4 year period, 155 subjects underwent defecography ( 45 males and 110 females ranging in age from $17-71$ years [ mean 52 years ]). Of the 155 patients, 95 in an age group similar to the 32 control subjects ( 41 - 71 years) were selected; there were 64 women and 31 men. For optimal comparison, the patient group was then matched by sex to the controls, so that 19 males and 13 females were selected from the 95 subjects with the aid of the random sample generator of the Epistat Statistical Package (version 3.0, 1984). The control group consisted of 19 men and 13 women, aged $41-71$ years (mean, 58 years), who were referred for barium enema study and who had no history of defecation disturbances. 
Because the condition and the physiologic characteristics of the pelvic floor muscles in patients with predominant symptoms of constipation could differ from those of patients with incontinence, the patient group was divided into these two subgroups.

Radiologic measurements of anorectal function in the control subjects have been reported previously (6), as were the standardized technique and the method used for the various measurements.

Several films that were representative of the various stages of defecation (squeezing,rest and straining) were selected, and the following variables were assessed: (a) the anorectal angle. (b) the position of the anorectal junction relative to the tip of the coccyx. (c) the width of the anal canal, and (d) the occurrence of rectal wall abnormalities.

The data from the two subgroups of patients (those with constipation and those with incontinence) were compared separately with the results of the control subjects. Statistical analysis was carried out with the Wilcoxon rank sum test for independent samples. The results were defined as statistically significant when the level of significance ( $p$-value) was $<0.01$.

For further comparison, a retrospective analysis was performed of the morphologic abnormalities of the anorectal region as seen on the defecograms of 155 consecutive patients referred with a variety of defecation disorders, including: straining at stool, feeling of incomplete evacuation, constipation, incontinence, rectal bloodloss and mucus discharge.

\section{RESULTS}

Table 1 displays the results of the statistical analysis. For most variables, the differences between the 32 controls, the matched group of 32 patients and the entire group of 155 patients were not statistically significant. The only significant difference was in the width of the anal canal; they were wider during squeezing and at rest in the patients than in the control subjects. During defecation straining, however, the difference in width was not significantly different. Furthermore, all measurements were associated with large standard deviations, indicating large interindividual variations.

Approximately twice as many patients as control subjects had abnormal defecograms (Table 2). These abnormalities included distinct outpocketings of the rectal wall during defecation straining (rectocele), infoldings 
Table 1. Measurements of Anorectal Motility in 32 Control Subjects and 32 Patients.

\begin{tabular}{llll}
\hline Variable & & \multicolumn{2}{l}{ Symptomatic patients } \\
\cline { 3 - 4 } & $\begin{array}{l}\text { Control } \\
\text { subjects } \\
(n=32)\end{array}$ & $\begin{array}{l}\text { Constipation Incontinence } \\
(n=19)\end{array} \quad(n=13)$ & $\begin{array}{l}\text { Signi- } \\
\text { ficant * }\end{array}$
\end{tabular}

\section{Squeezing}

$\begin{array}{llllll}\text { ARA } & 83^{\circ} \pm 22^{\circ} & 80^{\circ} \pm 23^{\circ} & 84^{\circ} \pm 33^{\circ} & 0.90 & \text { No } \\ \text { ARJ } & 0.5 \pm 2.0 & 0.2 \pm 2.1 & 0.7 \pm 2.3 & 0.74 & \text { No } \\ \text { ACW } & 0 & 0.20 \pm 0.28 & 0.28 \pm 0.46 & 0.003 & \text { Yes }\end{array}$

\section{Rest}

ARA

ARJ

$A C W$

$107^{\circ} \pm 24^{\circ}$

$$
103^{\circ} \pm 22^{\circ}
$$

$102^{\circ} \pm 30^{\circ}$

0.70 No

$-2.3 \pm 1.8$

$-1.5 \pm 2.5$

0.42 No

0

$0.27 \pm 0.53$

$0.47 \pm 0.64$

0.0002 Yes

\section{Straining}

ARA

$125^{\circ} \pm 19^{\circ}$

$121^{\circ} \pm 30^{\circ}$

$128^{\circ} \pm 41^{\circ}$

$0.56 \quad$ No

ARJ

$-4.0 \pm 2.0$

$-4.0 \pm 2.4$

$-3.6 \pm 3.3$

0.96 No

ACW

$1.7 \pm 0.44$

$1.07 \pm 0.53$

$1.46 \pm 0.71$

0.28 No

ARA

$\begin{array}{llllll}\text { Rest } \rightarrow \text { Straining } & 17^{\circ} \pm 24^{\circ} & 19^{\circ} \pm 25^{\circ} & 26^{\circ} \pm 27^{\circ} & 0.52 & \text { No } \\ \text { Rest } \rightarrow \text { Squeezing } & 23^{\circ} \pm 19^{\circ} & 22^{\circ} \pm 13^{\circ} & 18^{\circ} \pm 16^{\circ} & 0.72 & \text { No }\end{array}$

ARJ
Rest $\rightarrow$ Straining
$2.4 \pm 1.8$
$1.7 \pm 1.4$
$2.1 \pm 1.8$
0.44 No
Rest $\rightarrow$ Squeezing $2.3 \pm 1.4$
$2.1 \pm 1.5$
$2.2 \pm 1.4$
0.87 No

Note.- Measurements are provided as mean \pm standard deviation. \# "Anorectal junction" indicates position of junction relative to the tip of the coccyx. + Wilcoxon rank sum for independent samples. "Level of significance. $p<0.01$.

of the contours of the anorectum (intussusception or prolapse) or a combination of these (intussusception and rectocele) (Table 3 ). In some patients in whom there was only a slight indentation of the rectal wall, differentiation between mucosal prolapse or intussusception of the entire 
Table 2. Classification of Defecograms.

\begin{tabular}{lccc}
\hline & $\begin{array}{l}\text { Control subjects } \\
n=32\end{array}$ & $\begin{array}{l}\text { Patients } \\
n=32\end{array}$ & $\begin{array}{l}\text { Total consecutive patients } \\
n=155\end{array}$ \\
\hline Normal & $17(53 \%)$ & $12(38 \%)$ & $32(21 \%)$ \\
Abnormal & $10(32 \%)$ & $19(59 \%)$ & $113(73 \%)$ \\
Equivocal & $5(16 \%)$ & $1(3 \%)$ & $10(6 \%)$ \\
\hline
\end{tabular}

rectal wall was difficult. Three of the 155 patients had the descending perineum syndrome; in this condition the anorectal junction is abnormally low, more than $4 \mathrm{~cm}$ below the level of the tip of the coccyx, because of lax pelvic floor muscles.

Most often this condition is associated with faecal incontinence.

Patients in both subgroups had a so called solitary rectal ulcer, in which rectal lesions occur in association with functional abnormalities of the anorectum. Patients with the spastic pelvic floor were unable to relax the pelvic floor muscles during defecation; as a consequence, the anorectal angle did not increase, and there was no evacuation of contrast material at defecation straining. In five control subjects the anorectal angle decreased paradoxically during strairing; however, these subjects were able to evacuate most of the rectal contents. In patients from all groups, there were some equivocal findings, in that because minimal rectal wall changes occurred, the findings were difficult to classify.

\section{DISCUSSION}

The anorectal angle and the amount of perineal descent during defecation straining are the most frequently used indicators of the condition and physiologic status of the pelvic floor muscles. Ordinarily the pelvic floor relaxes during defecation straining, resulting in an increased anorectal angle, a descent of the anorectal junction and a widening of the anal canal.

An inability to relax the pelvic floor muscles has been recognized by several authors as a cause of obstructed defecation (10-12). Radiologic assesment of the changes in angulation between rest and defecation to 
Table 3. Findings at Defecography

\begin{tabular}{llll}
\hline Findings & $\begin{array}{l}\text { Control } \\
\text { Subjects } \\
(n=32)\end{array}$ & $\begin{array}{l}\text { Patients } \\
\text { Consequtive } \\
(n=32)\end{array}$ & $\begin{array}{l}\text { Total } \\
\text { Patients } \\
(n=155)\end{array}$ \\
\hline Intussusception & $4(13 \%)$ & $7(22 \%)$ & $29(19 \%)$ \\
$\begin{array}{l}\text { Spastic pelvic floor syndrome } \\
\text { Solitary rectal ulcer }\end{array}$ & 0 & $6(19 \%)$ & $23(15 \%)$ \\
Intussusception + rectocele & 0 & $2(6 \%)$ & $20(13 \%)$ \\
Rectocele & $3(9 \%)$ & $1(3 \%)$ & $11(7 \%)$ \\
Prolapse & 0 & $1(3 \%)$ & $9(6 \%)$ \\
Mucosal prolapse or & $3(9 \%)$ & $2(6 \%)$ & $4(3 \%)$ \\
$\quad$ intussusception (possible) & 0 & 0 & $6(4 \%)$ \\
Descending perineum syndrome & 0 & 0 & $3(2 \%)$ \\
Rectovaginal fistula & $5(16 \%)$ & $1(3 \%)$ & $1(0.6 \%)$ \\
Equivocal & 0 & 0 & $7(6 \%)$ \\
Unexplained inability to evacuate & 0 & & $7(5 \%)$ \\
Total & $15(47 \%)$ & $20(63 \%)$ & $123(80 \%)$ \\
\hline
\end{tabular}

Note. - Five subjects showed a decrease of the anorectal angle during straining but evacuated most of the rectal contents.

indicate the physiologic status of these muscles has been recommended prior to resection of the puborectalis muscle in the chronically constipated patient (13). Womack et al. (14), however, studied the anorectal function in these subjects and reported no significant differences in the anorectal angles at defecation straining between the constipated subjects and in control subjects. Using manometry, Kuijpers (15) showed decrease of anal resting pressures in incontinent patients, which should be attributed to weak sphincter ani and pelvic floor muscles, and was accordingly associated with obtuse resting anorectal angles. Contradictory findings, however, were reported by Bartolo (16), who found no significant differences in the anorectal angulations between continent and incontinent subjects. Recently, Pilloni et al. (17) confirmed this observation, and moreover, they stated that there were no differences in 
the excursion of the anorectal junction between normal and incontinent subjects.

It has been our impression that no obvious relationship exists between the defecographic measurements and clinical symptoms. The results from this study confirmed our presumption that radiologic measurements of anorectal function in patients with defecation disorders, whether the patients are constipated or incontinent, do not differ significantly from measurements in asymptomatic subjects.

Five of the control subjects failed to relax the pelvic floor muscles as evidenced by a decrease of the anorectal angle during straining. Despite this, most of the contrast material was evacuated. A similar observation was made by Kerremans (18) and Ihre (19) who described subjects, who had paradoxically increased electromyographic activity of the puborectalis, during expulsion of rectal contents. However, the patients in this study with the spastic pelvic floor syndrome demonstrated no increase in the anorectal angle and were also unable to empty the ampulla recti. By contrast, seven patients in our series (Table 3) were unable to evacuate the contrast medium despite normal measurements.

These contradictory findings, together with the fact that there are no significant differences in the anorectal angle and the excursions of the anorectal junction between the control subjects and the patients (whether constipated or incontinent), indicate that defecographic measurements cannot be regarded as reliable indicators of the complex physiologic condition of the pelvic floor muscles.

The width of the anal canal during squeezing and rest differed significantly between the symptomatic patients and control subjects. During straining, however, the differences were not significant; which suggests that these observations are probably of no clinical consequence.

The occurrence of anatomical rectal wall abnormalities in a large proportion of the matched group and the total consecutive patient group was the most striking finding in this investigation. Rectal wall intussusception, rectocele (whether accompanied by an intussusception or not), the spastic pelvic floor syndrome and the solitary rectal ulcer syndrome were the most frequent findings at defecography in both symptomatic patient groups.

In our opinion, the main applications of defecography are (a) the detection of these anatomic abnormalities as a possible cause of defecation disturbances and (b) as an anatomic guide to any necessary surgical procedure. It is questionable whether the changes in the anorectal angle, 
the excursions of the anorectal junction, and the changes in the width of the anal canal during the successive stages of defecation sufficiently reflect the physiologic status of the pelvic floor. Therefore, diagnosis of the spastic pelvic floor and an abnormal perineal descent should not be based on defecographic measurements only but also on fluoroscopic findings, namely, the ability to evacuate the rectum or retain rectal contents. Moreover, the persistence of clinical symptoms should also be taken into account when treatment is recommended. 


\section{REFERENCES}

1. Brodén $B$, Snellman B. Procidentia of the rectum studied with cineradiography: a contribution to the discussion of causative mechanism. Dis Colon Rectum 1968; 11: 330-347.

2. Kuijpers HC, Strijk SP. Diagnosis of disturbances of continence and defecation. Dis Colon Rectum 1984; 27: 658-662.

3. Bartolo DCC, Roe AM, Virjee J, McC.Mortensen NJ. Evacuation proctography in obstructed defecation and rectal intussusception. Br.J.Surg. 1985; Suppl: S111S116.

4. Mahieu P, Pringot J. Bodart P. Defecography: II. Contribution to the diagnosis of defecation disorders. Gastrointest Radiol 1984; 9:253-261.

5. Ekberg O, Nylander G, Fork FT. Defecography. Radiology 1985; 155: 45-48.

6. Goei R, van Engelshoven J, Schouten $\mathrm{H}$, Baeten $\mathrm{C}$, Stassen $\mathrm{C}$. Defecography: Measurement of anorectal function in asymptomatic subjects. Radiology 1989; 173: 137-141.

7. Skomorowska E, Henrichsen S, Christiansen J, HegedÜs V. Videodefaecography combined with measurement of the anorectal angle and of perineal descent. Acta Radiologica 1987; 28: 559-562.

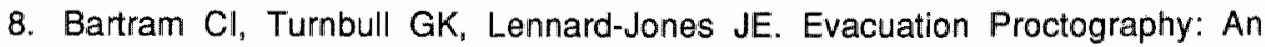
Investigation of Rectal Expulsion in 20 Subjects Without Defecatory Disturbance. Gastrointest Radiol 1988; 13: 72-80.

9. Shorvon P, Stevenson GW, Mc Hugh S, Somers S. Defecography: A study of normal volunteers. Radiology 1987; 165 (P) Supplement: 428 (abstract of Scientific Exhibit)

10. Wasserman IF. Puborectalis syndrome (rectal stenosis due to anorectal spasm). Dis Colon Rectum 1964; 7: 87-98.

11. Wallace WC . Madden WM. Experience with Partial Resection of the Puborectails Muscle. Dis Colon Rectum 1969; 12: 196-200.

12. Kuijpers HC, Schreve RH, Ten Cate Hoedemakers H. Diagnosis of functional disorders of defecation causing the solitary rectal ulcer syndrome. Dis Colon Rectum 1986; 29: 126-129.

13. Barnes PRH, Hawley PR, Preston DM, Lennard-Jones JE. Experience of posterior division of the puborectalis muscle in the management of chronic constipation. Br J Surg 1985; 72:475-477.

14. Womack NR, Williams NS, Holmfield JHM, Morrison JFB, Simpkins KC. New method for the dynamic assessment of anorectal function in constipation. $\mathrm{Br} J$ Surg 1985; 72: 994-998. 
15. Kuijpers HC. Fecal incontinence and the anorectal angle. The Netherlands journal of surgery $1984 ; 36-1: 20-23$.

16. Bartolo DCC, Read NW, Jarratt JA, Read MG, Donnelly TC, Johnson AG. Differences in anal sphincter function and clinical presentation in patients with the pelvic floor descent. Gastroenterology $1983 ; 85: 68-75$.

17. Piloni V, Ascoli G, Marmorale $\mathrm{C}$. Contribution of Defaecography to the Diagnosis of Faecal Incontinence. Colo-Proctology 1988; 5: 297-301.

18. Kerremans R. Morphological and physiological aspects of anal continence and defecation. Thesis University Hospital St.Rafaël 1969, Arscia SA, Brussels.

19. Ihre T. Studies on anal function in continent and incontinent patients. Scand J Gastroenterol 1974; 9 (suppl 25): 5-64. 


\section{Chapter 7}

\section{SOLITARY RECTAL ULCER SYNDROME Findings at barium enema study and defecography}

Reginald Goei, MD; Cor Baeten, MD; Blagoja Janevski, MD; Jos van Engelshoven, MD.

AJR 1987;149:933-936 (Preliminary Report)

Reginald Goei, MD; Cor Baeten, MD; Jan W Arends, MD. Radiology 1988;168:303-306

\section{ABSTRACT}

Sixteen cases of histopathologically proved solitary rectal ulcer syndrome were encountered. Fifteen cases underwent barium enema stu$d y$; in nine cases findings were non-specific including: rectal stricture, granularity of the mucosa and thickened rectal folds. In six cases the study was normal. All patients had a long history of defecation disorders, and defecography was performed in all. In seven cases intussusception of the rectal wall was seen; in another case the intussusception was accompanied by a rectocele. One case showed rectal prolapse. In four patients relaxation of the puborectalis failed which prevented the passage of the bolus; in another there was an abnormal perineal descent. In two patients studies were normal. Patients with a solitary rectal ulcer should undergo defecography to establish the diagnosis. 


\section{INTRODUCTION}

The solitary ulcer of the rectum consists of a benign mucosal lesion in the distal anterior wall of the rectum causing rectal bleeding and occurring mostly in young adults with a long history of defecation disorders. The condition was first described by Cruveilheir in 1870, and in 1969 Madigan and Morson first reviewed the condition extensively on the basis of 68 patients (1). Since in their series, $30 \%$ of the cases had more than one ulcer, it is remarkable that a misleading term "solitary ulcer" was introduced.

In 1975 Rutter and Riddell (2) stated that the majority of the patients with the solitary rectal ulcer syndrome strain at stool and that there is a clear connection between excessive straining and ulceration of the rectal mucosa. This observation was also made in several other large series (3-7).

To study the obvious presence of disturbances in bowel movements, we evaluated anorectal motility with fluoroscopy in 16 patients with histologically proved SRUS. To asses the value of double contrast barium enema in this condition, the examination was performed before defecography in 15 patients.

\section{MATERIALS AND METHODS}

Between March 1985 and February 1987, 16 cases with a long history of defecation disorders and rectal passage of blood or mucus visited our outpatient proctology department. The patients were between 18 and 80 years of age and there were four men and 12 women. All subjects had a history of defecation difficulties over several years with predominant complaints of straining, obstipation and a sensation of incomplete evacuation. Thirteen patients mainly had rectal bloodloss and three patients had excessive mucus discharge.

At proctoscopy, localized erosive, erythematous and ulcerative changes of the anterior rectal mucosa were seen in all subjects. Biopsy samples were taken from the lesions and were sent for histologic examination. In all cases the clinical diagnosis was confirmed by a pathologist (J.W.A.), according to the criteria described by Rutter and Riddell (2), including replacement of the lamina propria by fibroblasts and thickening of the muscularis mucosae. 
Within 7 days after endoscopy, 15 patients underwent double contrast barium enema study that was limited to the rectum.

Via a Milier air tip, $200 \mathrm{ml}$ of liquid Polibar (E-Z-EM Co, Westbury, NY) was instilled into the rectum. After drainage of barium, air was insufflated and the films were obtained in the anteroposterior, left lateral, and left posterior oblique positions.

After completion of the examination, defecography was performed as previously described (8). With the patient lying in the left lateral position, a thick barium contrast medium, with the consistency of feces was introduced into the rectum with use of a syringe and an enema tip. Usually $300 \mathrm{ml}$ was required to fill the entire rectum. The examination was performed with a remote controlled tilting examination table in the upright position. The patient is sitting on a special designed seat placed on the footrest of the table. The seat consists of a cylindrical pot made of radiolucent plastic. To prevent burning out of the images below the pelvis, water filled rubber tubes were placed in the pot. Under fluoroscopy in lateral projection $n_{y}$ the patient was asked to strain at stool and the various stages of defecation were photographed with use of a $105 \mathrm{~mm}$ camera.

Depending on the speed of excretion of the bolus, a frame rate of 1 film per second or 1 film per 2 seconds was used. In most cases 9 to 12 films were exposed. Three parameters were assessed:

(a) The anorectal angle, which represents the angle between the axis of the anal canal and a line drawn along the lower border of the distal rectum (Fig. 1a). In the resting state the puborectalis acts as a constrictor to the anorectal junction and causes a sharp angulation of $80^{\circ}-92^{\circ}$ $(9,10)$ (Fig. 1a). During defecation, straining is accompanied by a relaxation of the puborectalis, resulting in a downward movement of the anorectal junction and an increase of its angulation to $130^{\circ}-136^{\circ}(9,10)$ (Fig.1b). The walls of the rectum and the anorectal junction become funnel-shaped facilitating the passage of rectal contents (Fig.1b). (b) The amount of perineal descent. In normal subjects, at rest, the anorectal junction is located near or on the pubococcygeal line, which joins the most anterior point of the symphysis to the tip of the coccyx (Fig.1a). When the subject strains, the anorectal junction descends to $2 \mathrm{~cm}$ below the line or any other point of reference (11) (Fig.1b). (c) The contours of the barium filled rectum in lateral projection. During defecation, these should remain smooth without indentations or outpocketings (Fig.1b). 

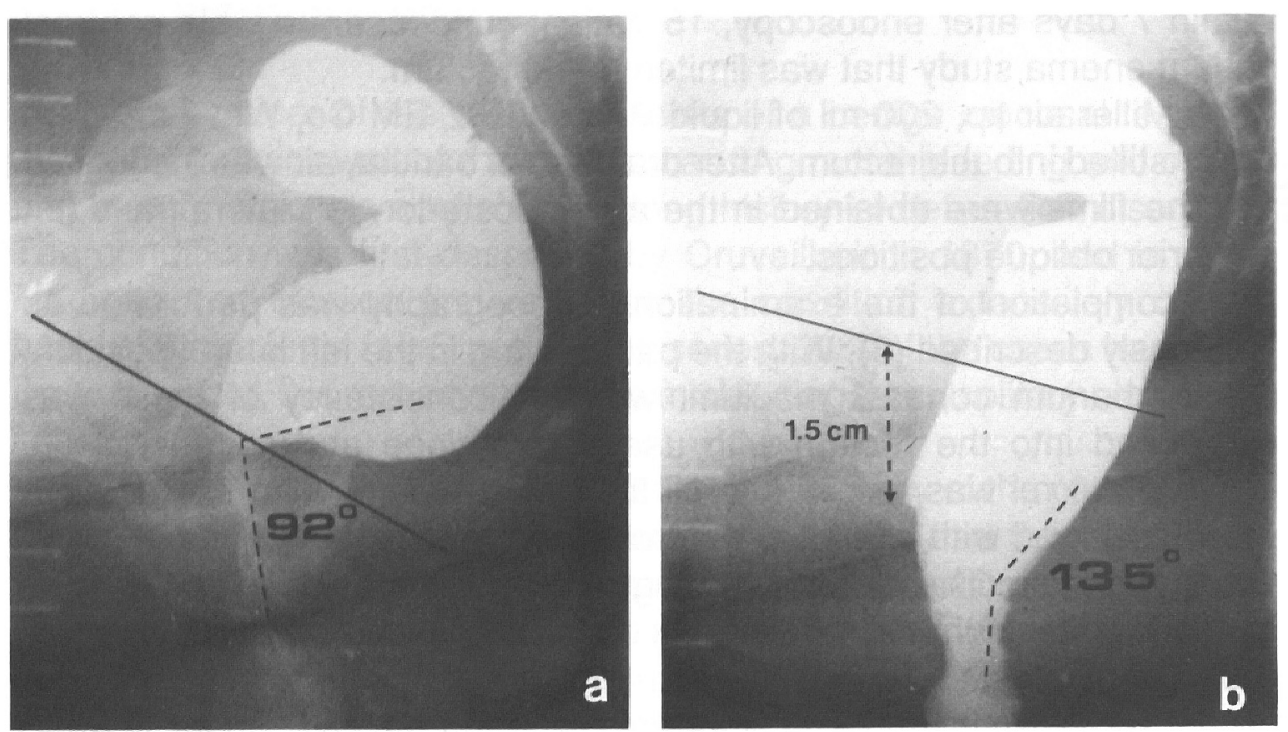

Figure 1. Normal defecograms. (a). At rest, the anorectal junction lies on the pubococcygeal line (solid line); the anorectal angle measures $92^{\circ}$ (dotted line).(b). During straining, the anorectal junction descends $1.5 \mathrm{~cm}$ (arrowheads) from the pubococcygeal line (solid line). As a result of relaxation of the puborectalis, the anorectal angle widens to $135^{\circ}$ (dotted line).

\section{RESULTS}

In two patients double contrast barium enema study showed granularity of the rectal mucosa (Fig.2). Two patients showed rectal strictures (Fig.3), and in five cases the valve of Houston was thickened (Fig.4). The study was normal in six. Defecography showed invagination of the rectal wall into the anal canal (intraanal rectal intussusception) in seven patients (Fig.5). In one patient the intussusception was accompanied by a rectocele (Fig.6). In another patient the head of the intussusception proceeded through the anal canal to form a rectal prolapse (Fig.7). In two cases there was little increase of the anorectal angle during straining because of nonrelaxation of the puborectalis. In one patient, there was a decrease in the angle during defecation (Fig.8), and in another patient the spasm was transient; after a few minutes of straining the impression 


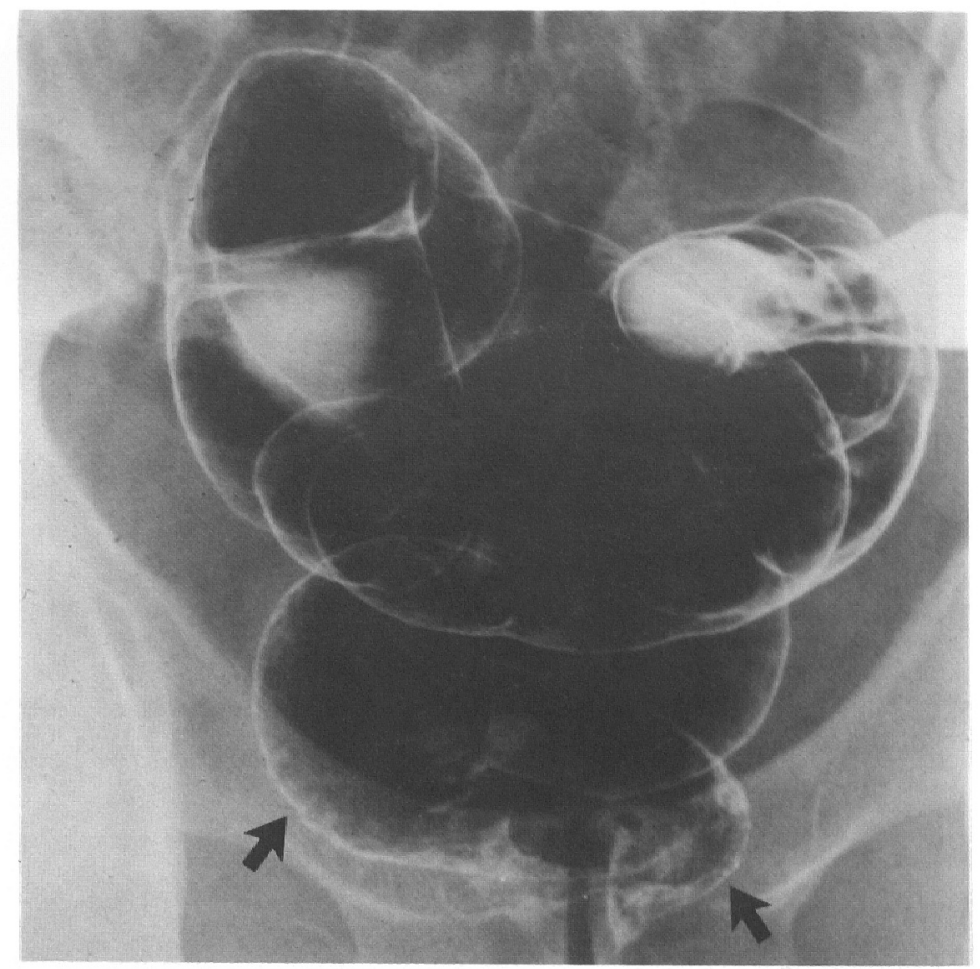

Figure 2. Anteroposterior view of rectum shows granularity of the mucosa (arrows) in a 53-year-old man with the spastic pelvic floor syndrome and an erosion seen at sigmoidoscopy.

on the anorectal junction suddenly obliterated and the anorectal angle widened as a result of relaxation of the puborectalis.

In one patient, at rest the anorectal junction lay $4 \mathrm{~cm}$ below the pubococcygeal line (Fig.9); during defecation, rectal prolapse was observed (Fig.9). In the remaining two patients, defecograms were normal.

\section{DISCUSSION}

The SRUS is an entity that consists of a benign rectal lesion accompanied by disorders of defecation and anal passage of blood or mucus. 


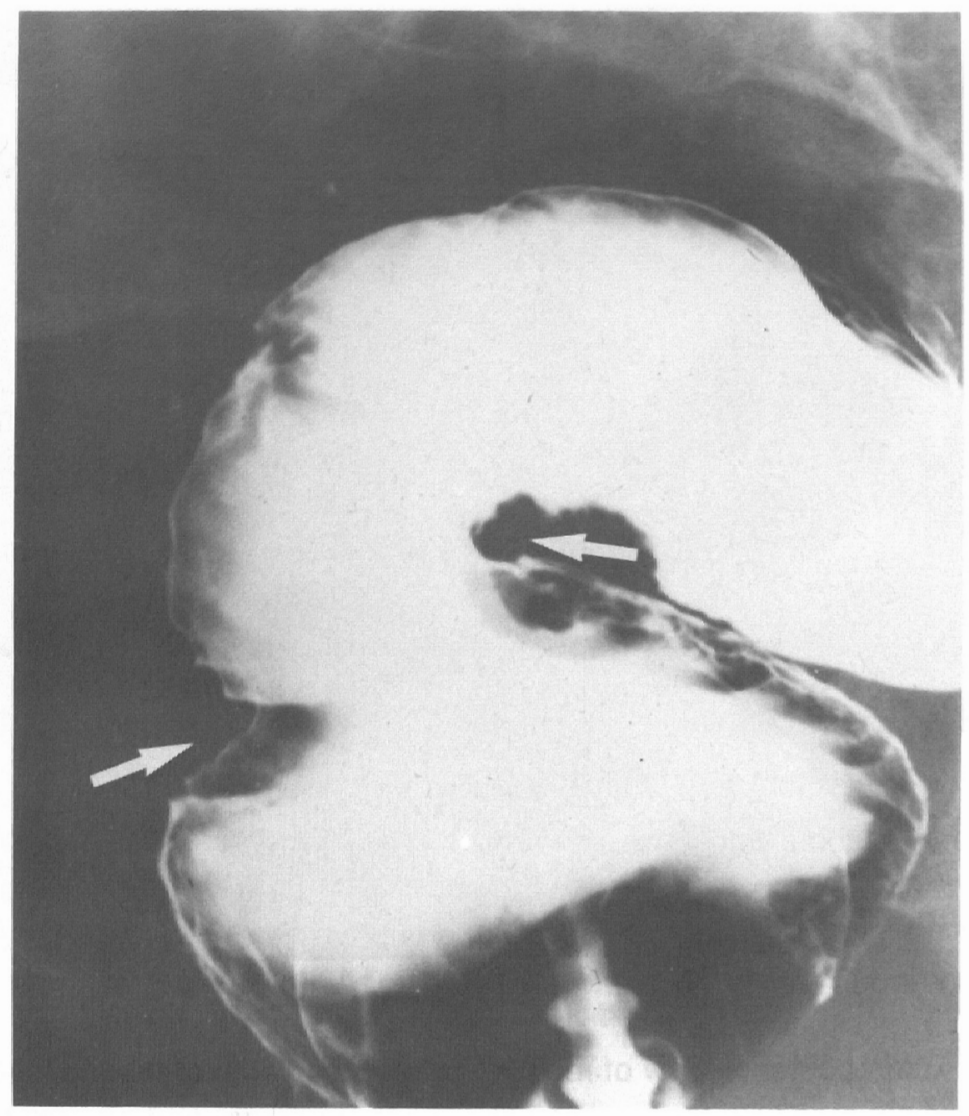

Figure 3. Oblique view of rectum shows stricture (arrows) in a 30-year-old woman with abnormal perineal descent and rectal prolapse seen at defecography. Multiple ulcers were seen at endoscopy.

Most patients described in the literature (2-7) are below the age of 40 years, in our series, however, $50 \%$ of the patients were older. In the current study, the rectal lesions in four cases consist of one ulcer. In five cases there were multiple ulcers, and in seven cases the only finding was an erosion or erythema. We therefore believe that the term solitary rectal ulcer is misleaciing. Rutter and Riddell (2) added the word "syndrome" to the condition because it was associated with other anorectal disorders such as rectal prolapse and dysfunction of pelvic floor musculature. Later, several authors described the syndrome in associa- 


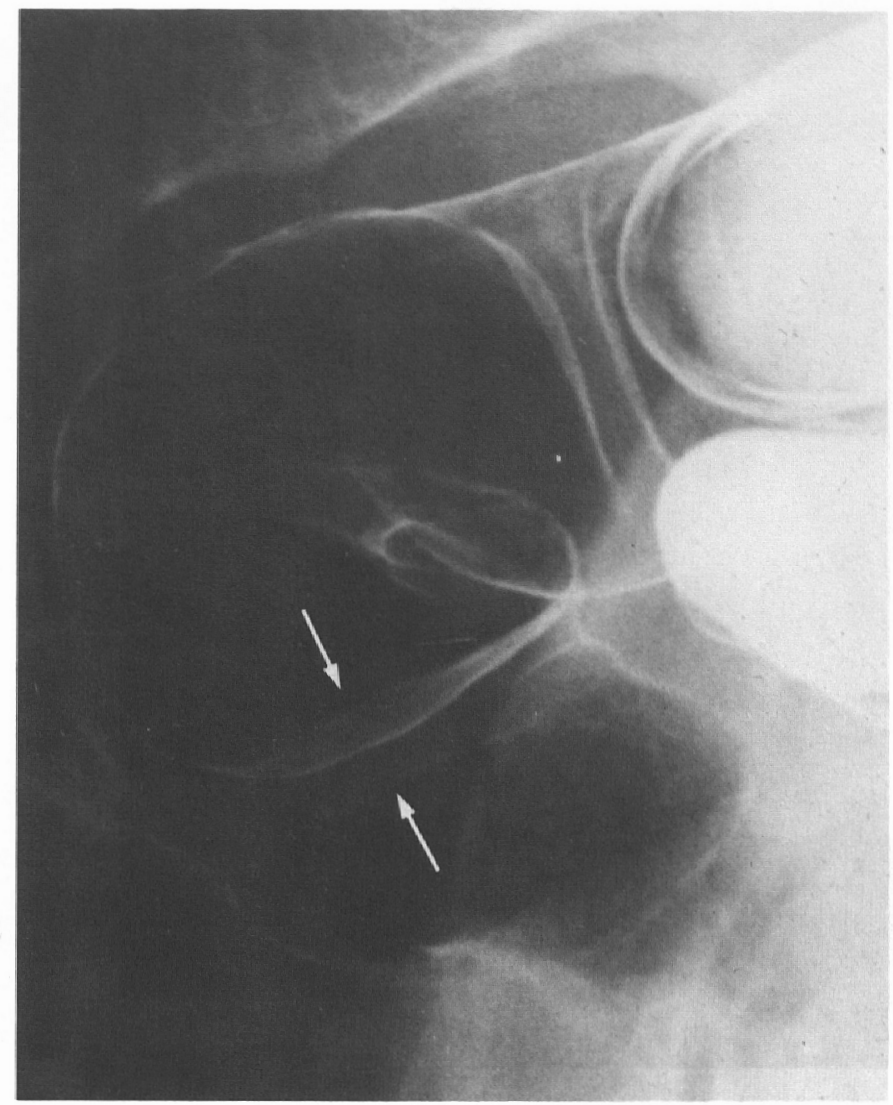

Figure 4. Lateral radiograph of the rectum in a 71-year-old woman with rectal intussusception and multiple ulcers. The valve of Houston is edematous and thickened (arrows). No ulcers were seen radiographically.

tion with clinically evident external rectal prolapse (3-5) and occult rectal prolapse $(12,13)$.

A causative relationship between the SRUS and rectal prolapse therefore seems likely. In fact, intraanal rectal intussusception is synonymous to occult rectal prolapse and is difficult to detect by clinical inspection.

Barium enema study and endoscopy are static examinations that do not allow detection of functional abnormalities. Even proctoscopic examination during straining cannot reveal these abnormalities (5). Defecography, however, is a dynamic study that appears suitable for revealing 


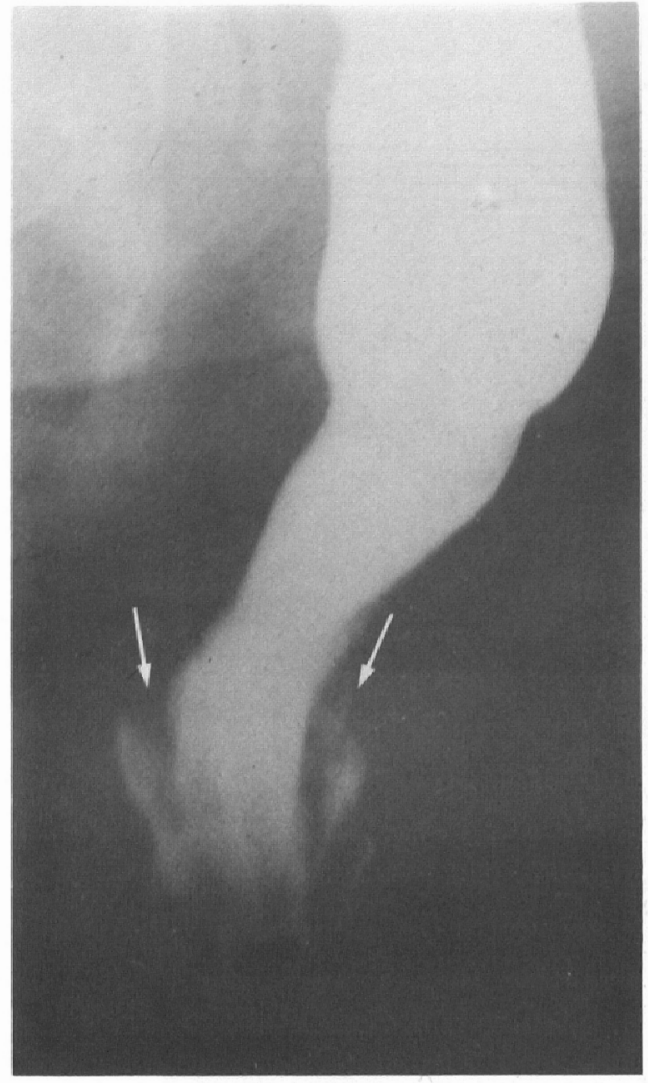

Figure 5. Intraanal rectal intussusception. The distal rectum invaginates into the anal canal (arrows).

intraanal rectal intussusception, which can be considered a precursor to external rectal prolapse, in which the rectal wall protrudes through the anal orifice.

In cases of intraanal rectal intussusception the proximal rectal wall intussuscepts into the lumen of the distal rectum blocking the anal canal during straining which leads to incomplete evacuation and repeated straining, thus setting up a vicious circle.

The pathogenesis of the rectal lesions in the SRUS in cases of rectal prolapse and intussusception is thought to be mechanical injury to the mucosa resulting in rupture of submucosal vessels and ischemia.

The puborectalis muscle and the deep portion of the external sphincter muscle are fused together and this structure is called the "top loop" (14). Both muscles arise from the back of the symphysis pubis proceed backward and downward along the upper part of the anal canal, and form 


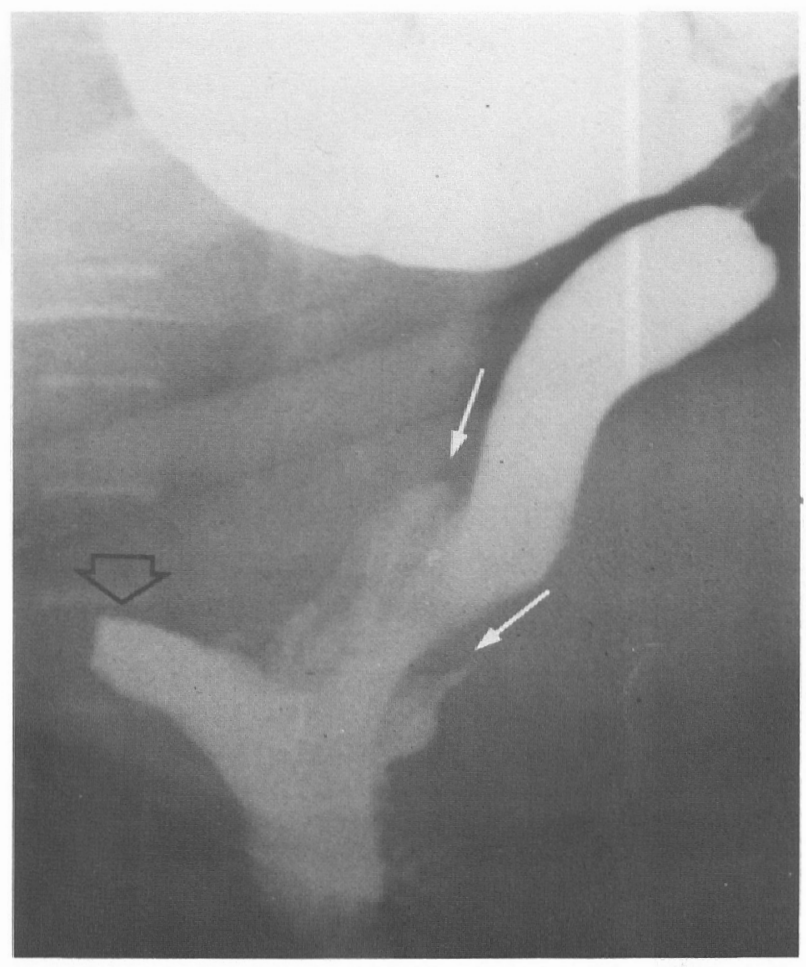

Figure 6. Intraanal rectal intussusception (solid arrows) with a rectocele (open arrow).

a U-shaped loop behind the anorectal junction (14). In the resting state the puborectalis acts as a constrictor to the anorectum which results in anorectal angulation of $80^{\circ}-90^{\circ}$. Any increase in intraabdominal pressure forces the anterior rectal wall against the upper anal canal, thereby effectively occluding it (9). In this way, these muscles play an important role in controlling continence. During defecation the puborectalis relaxes resulting in obliteration of the impression at the posterior wall of the anorectal junction and widening of the anorectal angulation. The anorectum is converted into a funnel shape enabling the passage of stool.

In four of our cases, we observed dysfunction of the puborectalis that prevented expulsion of rectal contents despite repeated straining. Two of these cases showed incomplete relaxation of the muscle resulting in insufficient increase of the anorectal angle. In one case, the puborectalis acted paradoxically and contracted during defecation, accentuating the imprint of the muscle at the posterior rectal wall and resulting in a 


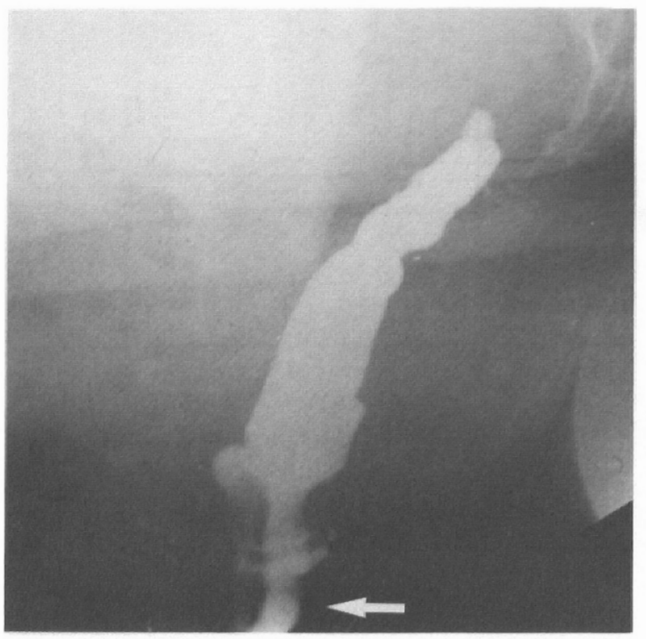

Figure 7. Protrusion of the rectal intussusception through the anal verge forming a rectal prolapse (arrow).
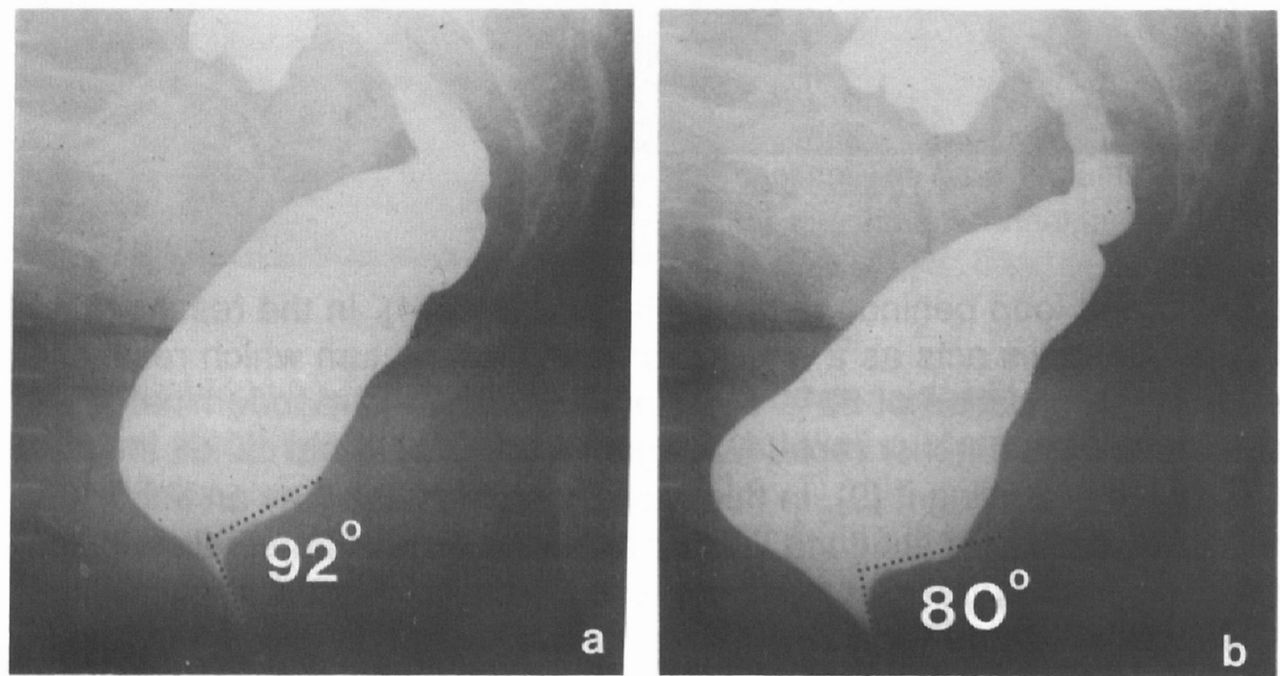

Figure 8. Spastic pelvic floor syndrome. (a). At rest, the anorectal angle measures $92^{\circ}$ (dotted line). (b). During straining, contraction of the puborectalis instead of relaxation results in a decrease of the anorectal angle to $80^{\circ}$ (dotted line). There was no excretion of rectal contents. 

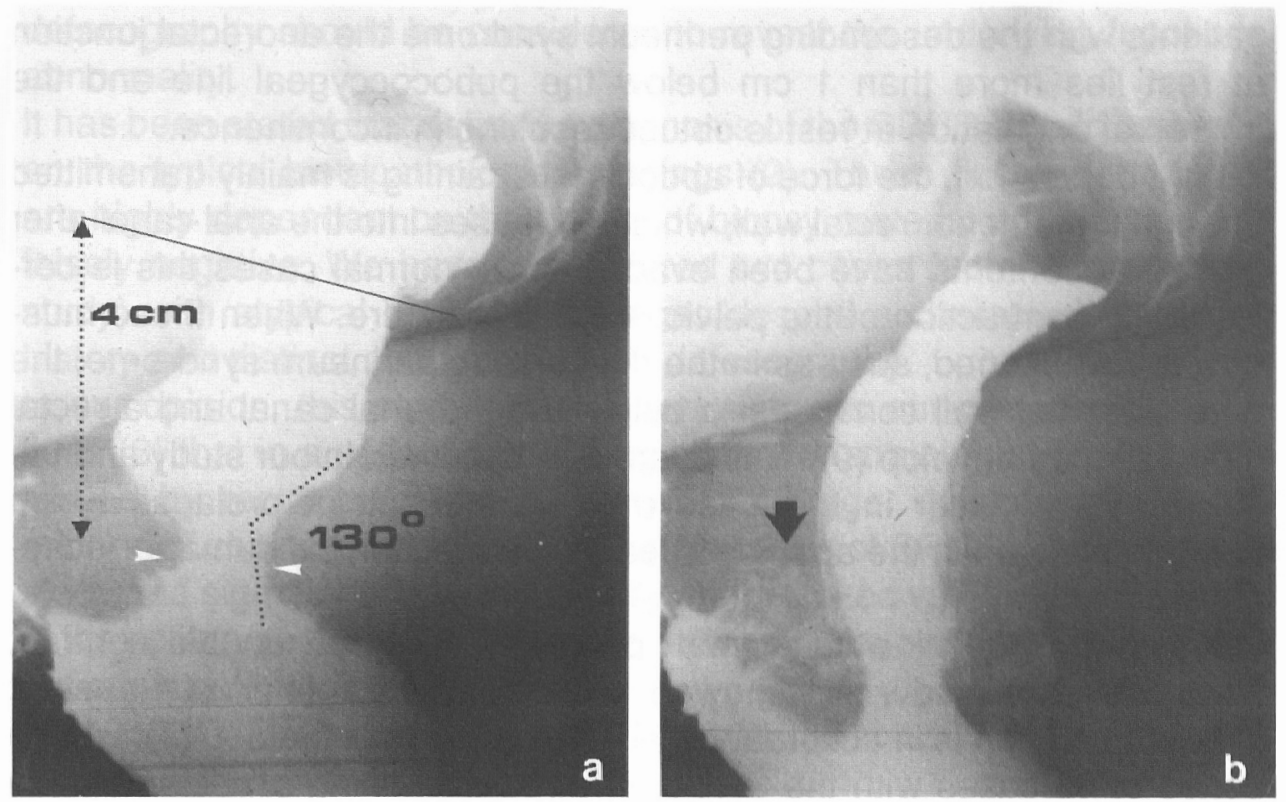

Figure 9. Abnormal perineal descent associated with rectal prolapse. (a). At rest, there is abnormal position of the anorectal junction $4 \mathrm{~cm}$ below the pubococcygeal line (solid line). The anorectal angle is straightened to $130^{\circ}$ (bent dotted line). The anal canal is widened (arrowheads), and the patient is incontinent.(b). During straining, a rectal prolapse occurred (arrow).

decrease of the anorectal angle. In another case, the spasm was transient.

Spasm of the puborectalis was first described extensively by Wasserman in 1963 (14) and recently several authors described the spastic pelvic floor syndrome in association with the SRUS $(6,7,15)$.

Compression and abrasion of the contracted puborectalis against the anterior rectal wall during straining might cause the lesions in the SRUS (2).

In one of our cases, abnormal perineal descent occurred. This condition is a functional abnormality of the pelvic floor in which the pelvic floor muscles are weakened due to a long period of excessive straining. Lengthening of pelvic floor muscles occurs, resulting in sagging of the pelvic floor and increased anorectal angulation. In normal persons, at rest the anorectal junction lies on or near the pubococcygeal line. In 
patients with the descending perineum syndrome the anorectal junction at rest lies more than $1 \mathrm{~cm}$ below the pubococcygeal line and the anorectal angulation at rest is obtuse resulting in incontinence.

During defecation, the force of abdominal straining is mainly transmitted through the anterior rectal wall, which prolapses into the anal canal after the rectal contents have been evacuated. In normal cases this is corrected by contraction of the pelvic floor musculature. When these muscles are weakened, such as in the descending perineum syndrome, the anterior rectal wall continues to bulge into the anal canal and a rectal prolapse may develop (9). This event was observed in our study and the solitary rectal ulcer in this case may be a result of prolapse which became plugged in the anal canal leading to mechanical damage, ische mia and ulceration.

In this series, of nine cases with positive findings at double contrast barium enema study, five showed thickening of the folds of Houston. This observation is in accordance with the findings of Mahieu (7), whose series of 43 cases with the SRUS, showed thickening of rectal folds in $79 \%$. The location of most lesions near a valve of Houston in our series and those mentioned in the literature (1) would explain why thickening of rectal folds is the most common feature in the SRUS.

The two patients with granularity of the rectal mucosa had erosive and erythematous changes on sigmoidoscopy. These findings closely correlate with those of Feczko and Millward $(16,17)$, that this radiographic abnormality corresponds to the preulcerative phase of the syndrome.

Although in eight cases there were ulcerative changes on endoscopy, none of these were detected at barium enema study. In three cases there were thickened rectal folds, two cases showed rectal stricture, and in the remaining three, no abnormalities were detected. A variety of the appearances of the rectal ulcers at barium enema study, was also noted in other reports $(16,17)$. It can therefore be concluded that the changes at barium enema study differ very much in the SRUS and that differentiation from other conditions such as carcinoma or inflammatory proctitis cannot be made.

However, thickening of the valve of Houston is the most common finding at barium enema study in the SRUS; although it can also result from earlier stages of ulcerative colitis (18), its presence in a patient with a long history of straining at stool in association with rectal bloodloss or mucus discharge is highly suggestive for the syndrome. In these cases, 
defecography should be considered to reveal the underlying functional abnormality.

It has been stated that definitive diagnosis of the SRUS should be based on the typical histopathological findings (2). These findings, however, are highly dependent on the quality of biopsy material and thus can be falsely negative. We have encountered two cases (not included in this study) with atypical histologic changes despite a characteristic clinical history and distinct abnormalities on defecography.

In our opinion, this study extends and supports our previous observations (8) that in a patient with a long history of straining at stool accompanied by rectal bloodloss or mucus discharge, defecography is the method of choice for establishing the diagnosis of SRUS. Barium enema study and sigmoidoscopy with biopsy are of limited value in the detection of the solitary rectal ulcer syndrome and should be performed only to rule out other pathologic conditions. 


\section{REFERENCES}

1. Madigan MR, Morson BC. Solitary ulcer of the rectum. Gut $1969 ; 10: 871-881$

2. Rutter KR, Riddell RH. The solitary ulcer syndrome of the rectum. Clin Gastroenterology $1975 ; 4: 505-530$

3. Kennedy DK, Hughes ESR, Masterton JP. The natural history of benign ulcer of the rectum. Surg Gynecol Obstet 1977; 144:718-720

4. Martin CJ, Parks TG, Biggart JD. Solitary rectal ulcer syndrome in Northern Ireland 1971-1980. Br J Surg 1981;68:744-747

5. Ford MJ, Anderson JR, Gilmour HM, Holt S, Sircus W, Heading RC. Clinical spectrum of "Solitary Ulcer" of the rectum. Gastroenterology 1983; 84:15331540

6. Kuypers $H C$, Schreve $R H$, ten Cate Hoedemakers $H$. Diagnosis of functional disorders of defecation causing the solitary rectal ulcer syndrome. Dis Colon Rectum 1986; 29: 126-129

7. Mahieu PHG. Barium enema and defecography in the diagnosis and evaluation of the solitary rectal ulcer syndrome. Int $\mathrm{J}$ Colorect Dis 1986; $1: 85-90$

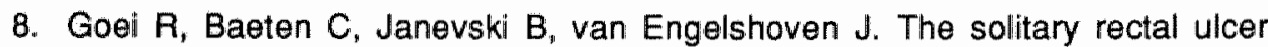
syndrome: Diagnosis with defecography. AJR; 1987; 149:933-936

9. Hardcastle JD. The descending perineum syndrome. The Practitioner 1969; 203:612-619

10. Mahieu P, Pringot J, Bodart P: Defecography. I. Description of a new procedure and results in normal patients. Gastrointest Radiol 1984; 9:247-251

11. Bartolo DCC, Read NW, Jarratt JA, Read MG, Donnelly TC, Johnson AG. Diferences in anal sphincter function and clinical presentation in patients with pelvic floor descent. Gastroenterology 1983; 85:68-75

12. Schweiger M, Alexander-Williams J. Solitary Ulcer Syndrome of the rectum: its association with rectal prolapse. Lancet 1977; 1:170-171

13. White CM, Findlay JM, Price JJ. The occult rectal prolapse syndrome. Br J Surg $1980 ; 67: 528-530$

14. Shafik A. A New concept of the anatomy of the anal sphincter mechanism and the physiology of defecation. II Anatomy of the Levator Ani muscle with special reference to puborectalis. Invest. Urology $1975 ; 13: 175182$

15. Wasserman IF. Puborectalis Syndrome (Rectal Stenosis Due to Anorectal Spasm). Dis Colon Rectum 1964; 7:87-98

16. Feczko PJ, O'Conell DJ, Riddell RH, Frank PH. Solitary Rectal Syndrome: Radiologic Manifestations. AJR 1980; 135:499-506 
17. Millward SF, Bayjoo P, Dixon MF, Williams NS, Simpkins KC. The Barium Enema Appearances in Solitary Rectal Ulcer Syndrome. Clin Rad 1985; 36:185189

18. Russel JGB, Donoghue V. Rectal Fold Thickness as an indicator of Disease. Clin Rad 1983; $34: 427-431$. 


\section{Chapter 8}

\section{RECTAL INTUSSUSCEPTION AND RECTAL PROLAPSE \\ Detection and postoperative evaluation with defecography}

Reginald Goei, MD; Cor Baeten, MD.

Radiology $1990 ; 174: 124-126$

\section{ABSTRACT}

The authors studied pre- and postoperative defecograms in 20 patients with rectal intussusception and three with rectal prolapse to asses the value of defecography in detection of these conditions. Eleven patients also had solitary rectal ulcers. Two to 3 months after surgery, patients underwent defecography, and results were correlated with postoperative symptoms. In all three patients with rectal prolapse, and 13 of 20 with intussusception, findings on postoperative defecograms were normal and symptoms were gone. Abnormalities and symptoms persisted in two patients and recurred in another two. In three patients, symptoms persisted despite normal defecographic findings. In 11 patients with solitary rectal ulcers, rectal lesions were cured in nine; in two intussusception and rectal lesions recurred. Thus, presence or absence of solitary rectal ulcer corresponded to postoperative symptoms in all cases. Symptoms and postoperative defecographic findings corresponded in 20 . 
This study suggests that rectal intussusception and prolapse most likely lead to defecation disorders and that defecography is useful in detecting them. Rectal prolapse and solitary rectal ulcer accompanied by rectal intussusception are the best indicators for surgical correction.

\section{INTRODUCTION}

Rectal intussusception is an abnormal condition, in which an invagination of the proximal rectal wall into the distal rectum forms during defecation and persists after the bolus has passed. When the lead point of the intussusception passes beyond the anal orifice, the condition is designated rectal prolapse. During downward straining, the intussusception occludes the anal canal, preventing further evacuation of rectal contents. Therefore, the most common symptom is incomplete emptying of the rectal ampulla. Rectal prolapse is usually easy to recognize at clinical examination, whereas rectal intussusception can be better detected during defecography, whereby the patient is expelling contrast material under fluoroscopic observation.

In our institution, surgical correction was performed in patients who had either rectal intussusception or rectal prolapse detected with defecography and who had severe and longstanding symptoms.

The purpose of our study was to assess the value of defecography in the detection of these conditions in the preoperative stage.

\section{PATIENTS AND METHODS}

From 1985 to 1988,155 subjects underwent defecography for a variety of defecation disturbances, including constipation, anal incontinence, a feeling of incomplete evacuation, straining at defecation, rectal bloodloss, or mucus discharge. Fifty-two subjects had rectal intussusception, and seven had rectal prolapse. Thirty six patients were not included in the study because they were not operated upon and were treated conservatively or there was no adequate follow up.

In 20 subjects with rectal intussusception and in three with rectal prolapse, the duration and the severity of the symptoms were such, that surgical correction was warranted. These 23 subjects constituted our study group and included seven men and 16 women, ranging in age from 
18 to 76 years, with a mean age of 55 years. In 19 patients, the main symptom was feeling of incomplete evacuation, along with a sensation of obstruction and straining at defecation. The remaining four patients complained primarily of fecal incontinence. To rule out organic bowel disease, sigmoidoscopy was performed in all patients. Ten patients with rectal intussusception and one with rectal prolapse had rectal lesions (including ulcerative, erythematous and erosive changes), which histopathologically proved to be solitary rectal ulcer. These patients had rectal bloodloss and/or mucus discharge, associated with constipation, a sensation of incomplete evacuation or a feeling of "something coming out".

Defecography was performed with the same technique (1) in all 23 patients. After the rectum was filled with a thick barium paste with the consistency of faeces, the patient was requested to sit on a specially designed seat while fluoroscopy was performed in lateral projection. With use of a $105 \mathrm{~mm}$ camera, nine to 12 films were exposed at a frame rate of 1 film per second or 1 film per 2 seconds. Images were obtained while the patient maximally contracted the pelvic floor muscles (squeezing), when the patient was asked to relax the pelvic floor muscles (at rest), and during evacuation of the rectal contents.

Rectal intussusception was defined as a considerable infolding of the rectal wall, which gradually descended toward the anal canal during defecation straining and which persisted after the bolus has passed (Fig.1). Rectal prolapse was defined as a protrusion of the intussusception through the anal orifice (Fig.2a).

All patients underwent surgical abdominal posterior fixation of the rectum to the sacrum with use of a Vicryl patch, according to the method described by Wells (2).

In contrast to the more generally performed Ripstein procedure (3)whereby the patch is applied to the whole circumference of the rectum-in the Wells procedure, the patch is folded arround approximately threefourths of the circumference of the rectum. Thus, a portion of the anterior rectal wall is left uncovered to prevent constriction of the lumen.

Approximately 2-3 months after surgery, a detailed clinical history was obtained from all patients, to evaluate the postoperative symptoms. All subjects underwent follow-up defecography, and follow-up sigmoidoscopy was performed in the 11 patients with a solitary rectal ulcer. Findings from postoperative defecograms were then correlated with the postoperative symptoms. 


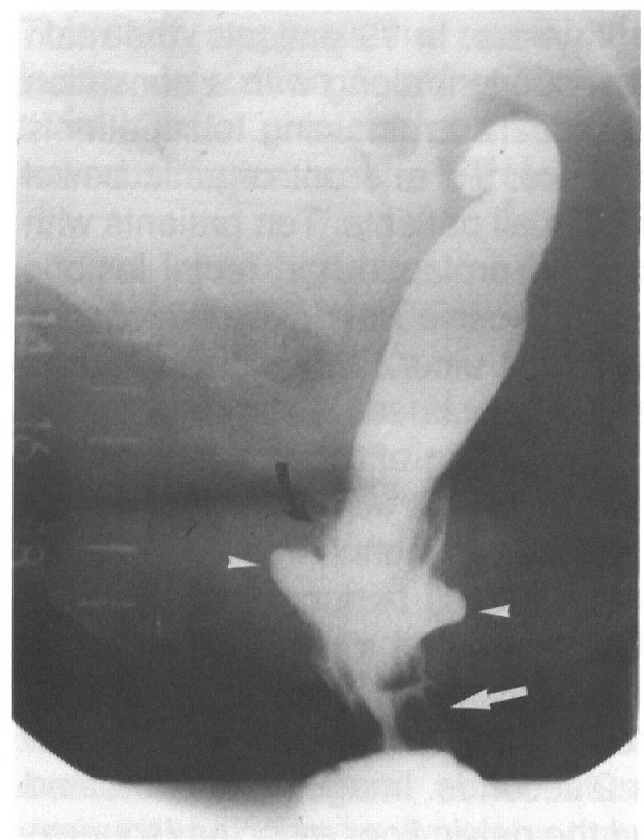

Figure 1. Circular intraanal rectal intussusception. Defecogram shows proximal rectal wall (curved arrow) invaginated into the distal rectum (arrowheads). The intussusceptum does not protrude through the anal canal (arrow).
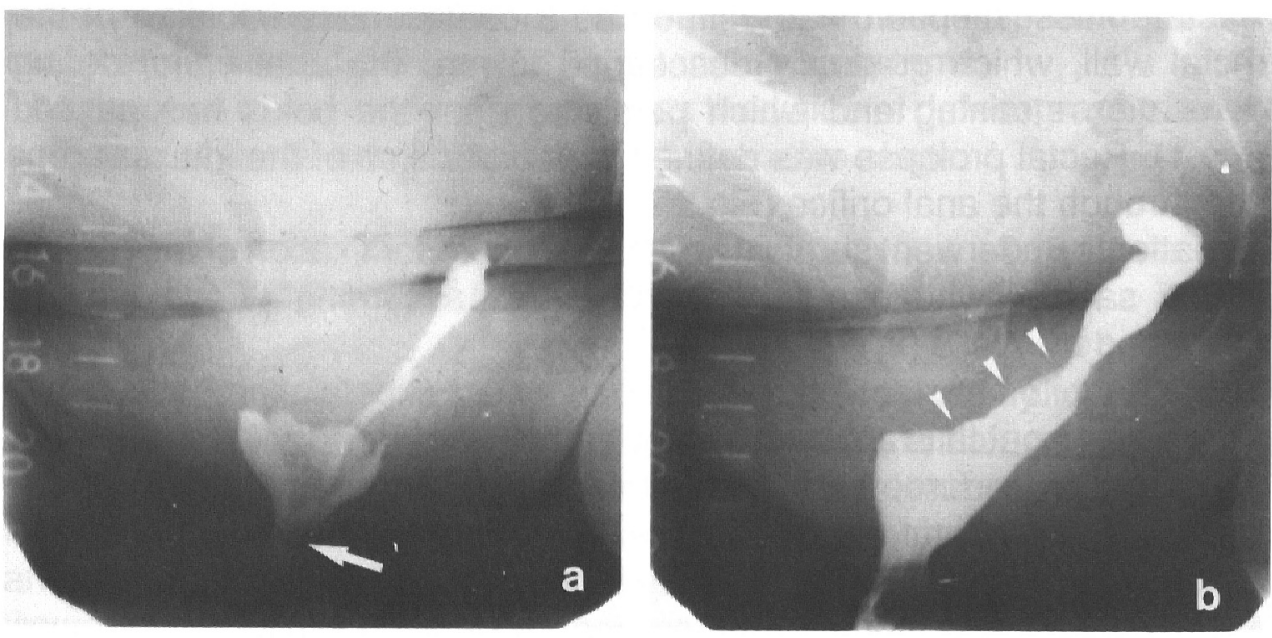

Figure 2. Rectal prolapse. (a). Preoperative defecogram shows apex of the intussusceptum, which has advanced through the anal canal and formed a rectal prolapse (arrow). (b). On postoperative defecogram, no invagination of the rectal wall is seen. Indentation at the anterior rectal wall at the patch site is well demonstrated (arrowheads). 


\section{RESULTS}

Table 1 summarizes the preoperative and postoperative findings from defecography and clinical history. In all three patients with rectal prolapse and in 13 of 20 patients with rectal intussusception, the rectal wall abnormalities were successfully corrected at surgery. This was evident from postoperative defecograms and because the patients were free of symptoms. Two patients experienced no improvement in symptoms, and defecograms demonstrated persistent rectal intussusception. In three patients, the complaints persisted postoperatively, although the intussusception was corrected and no postoperative stricturing was seen at follow-up defecography. In 10 patients with rectal intussusception accompanied by solitary rectal ulcers, the rectal lesions were healed completely in eight patients. In the remaining two patients, follow-up defecography at three months after surgery showed the intussusception was corrected and sigmoidoscopy showed the rectal lesions were healed. However, 8 months after surgery in one patient and 1 year in the other, the symptoms, rectal lesions and intussusception recurred. In the

Table 1. Recurrences at follow-up defecography and postoperative symptoms.

No. of Recurrences

\begin{tabular}{lllll} 
Preoperative Diagnosis & $\begin{array}{l}\text { No of } \\
\text { Patients }\end{array}$ & $\begin{array}{l}\text { Found at } \\
\text { Follow-up } \\
\text { Defecography }\end{array}$ & $\begin{array}{l}\text { Of } \\
\text { obstipation }\end{array}$ & $\begin{array}{l}\text { Of } \\
\text { incontinence }\end{array}$ \\
\hline
\end{tabular}

\begin{tabular}{lclll}
\hline Rectal intussusception & 10 & $2+$ & 4 & 1 \\
$\begin{array}{l}\text { Rectal intussusception and } \\
\text { solitary rectal ulcer }\end{array}$ & 10 & $2^{*}$ & $2^{*}$ & 0 \\
$\begin{array}{l}\text { Rectal prolapse } \\
\text { Rectal prolapse and }\end{array}$ & 2 & 0 & 0 & 0 \\
solitary rectal ulcer & 1 & 0 & 0 & 0 \\
Total & 23 & 4 & 6 & 1 \\
\hline
\end{tabular}

Note.- ${ }^{+}$Rectal wall abnormalities and the symptoms persisted postoperatively; * Initially intussusception and rectal ulcer were cured; later they recurred. 
Table 2. Relation between rectal abnormality and symptoms pre- and postoperatively.

\begin{tabular}{lccll}
\hline & \multicolumn{2}{c}{ Preoperative } & \multicolumn{2}{c}{ Postoperative } \\
& RI & RP & RI & RP \\
\hline Obstructed defecation & 17 & 2 & 3 & 0 \\
Faecal incontinence & 3 & 1 & 1 & 0 \\
Total & 20 & 3 & 4 & 0 \\
\hline
\end{tabular}

one patient with rectal prolapse and a solitary rectal ulcer, the rectal lesions were healled and there were no recurrences.

Of four patients with recurrent or persistent rectal intussusception, three had obstructed defecation. The last patient had postoperative fecal incontinence (Table 2).

\section{DISCUSSION}

Using cineradiography, Brodén and Snellmann (4) studied the mechanism of rectal intussusception, and clearly demonstrated that this condition eventually develops into a rectal prolapse.

To our knowledge the frequency of both conditions has not been clearly established. In a review of 3000 patients with complaints referable to the colon and anorectal region, Asman (5) found that $5 \%$ had clinical evidence of rectal prolapse or rectal intussusception. In our series of 155 consecutive patients who underwent defecography for a variety of defecation disturbances, prolapse or intussusception of the rectal wall was found in approximately $38 \%$.

The diagnosis of rectal intussusception at defecography should be based on a considerable infolding of the rectal wall toward the lumen during straining at defecation. A minimal infolding that disappears after the bolus has passed, is probably caused by a transient prolapse of the mucosa and should not be considered pathologic.

The cause of rectal intussusception and rectal prolapse is not fully understood. An abnormally deep pouch of Douglas, defective levator 
ani, insufficient attachement of the rectum, and redundancy of the sigmoid colon were regarded as predisposing factors (3-7). Ihre and Seligson (8) reported that most patients had symptoms of constipation and that the second most common complaint was faecal incontinence. This observation agrees with our findings that $83 \%$ of the patients had obstructed defecation and $17 \%$ had anal incontinence.

From several studies (9-11), it is obvious that intussusception of the rectal wall occurs in subjects without defecation disorders; therefore the question can be raised, as to whether, rectal intussusception and rectal prolapse are causes of defecation disturbances. Our study showed that in 20 of 23 patients, the presence or absence of abnormalities at the time of postoperative defecography was closely related to the occurence of postoperative symptoms. In 16 patients no abnormalities were found at follow-up defecography and the symptoms disappeared. In two patients, recurrence of symptoms and rectal lesions was accompanied by recurrence of the intussusception, and in another two, postoperative persistence of the intussusception was accompanied by persistence of the symptoms.

In three of our patients, constipation recurred despite a normal rectal wall seen at follow-up defecography. This phenomenon was reported earlier by Ahlbäck et al (12). In their series of 11 patients, five were constipated postoperatively even though no abnormalities were seen on the postoperative defecograms. The reason for this discrepancy is unclear. Although nerve damage during operation was thought to be the reason, the exact cause of the postoperative constipation is unknown.

Although our series was small and the follow up period was short, our results suggest that rectal intussusception and rectal prolapse are most likely the underlying causes of defecation disorders and that defecography is useful in detection of these conditions. Since the patients with rectal prolapse had neither recurrent symptoms nor abnormality and since the presence or absence of a solitary rectal ulcer corresponded to the postoperative symptoms in all cases, we think that a clinical or a defecographic finding of a rectal prolapse and the presence of a solitary rectal ulcer in association with a rectal intussusception are the best indicators for the Wells procedure. 


\section{REFERENCES}

1. Goel R, Baeten C, Arends JW. Solitary Rectal Ullcer Syndrome: Findings at Barium Enema Study and Defecography. Radiology 1988; 168:303-306.

2. Gordon PH. Ivalon Sponge Wrap and Thiersch operations for Rectal Prolapse. Mastery of Surgery, edited by Nyhus LM and Baker RJ. Little Brown and Company 1987; chapter 131:1045-1049.

3. Ripstein CB, Lanter B. Etiology and Surgical Therapy of Massive Prolapse of the Rectum. Ann of Surgery 1963; 157:259-264.

4. Brodén B, Snellman B. Procidentia of the Rectum Studied with Cineradiography: A Contribution to the Discussion of Causative Mechanism. Dis Colon Rectum 1968; 11:330-347.

5. Asman HB. Internal Procidentia of the Rectum. Southern Med J; 1957; 50:641645.

6. Nigro NM. Procidentia: The Etiology of Rectal Procidentia. Dis Colon Rectum 1972; 15:330-333.

7. Ryan P. Observations upon etiology and treatment of rectal prolapse. Austr NZ J. Surg. 1980; 50: 109-115.

8. Ihre T, Seligson U. Intussusception of the Rectum Internal Procidentia: Treatment and Results in 90 Patients. Dis Colon Rectum 1975; $18: 391-396$.

9. Bartram $\mathrm{Cl}$, Turnbull Gk, Lennard-Jones JE. Evacuation Proctography: An Investigation of Rectal Expulsion in 20 Subjects Without Defecatory Disturbance. Gastrointest Radiol 1988; 13:72-80.

10. Shorvon P, Stevenson GW, Mc Hugh S, Somers S. Defecography: A study of normal volunteers. Radiology 1987; 165 (P) Supplement:428 (abstract of Scientific Exhibit).

11. Goel R, van Engelshoven J, Schouten H, Baeten C, Stassen C. Anorectal Function: Defecographic Measurement in Asymptomatic Subjects. Radiology 1989; 173:137- 141.

12. Ahlbä́ck $S$, Brodén $B$, Brodén $G$, Ewerth $S$, Holmstrom B. Rectal Anatomy Following Ripstein's Operation for Prolapse Studied by Cineradiography. Dis Colon Rectum 1979; 22:333-335. 


\section{Chapter 9}

\section{RADIATION DOSE IN DEFECOGRAPHY}

Reginald Goei, M.D; Gerrit Kemerirk, Ph.D

Radiology (accepted)

\section{ABSTRACT}

Although there is an increased interest in defecography, there are no data available in the literature on radiation doses associated with this procedure. The effective dose equivalent, as an expression of total patient risk and gonadal doses associated with hereditary effects, were measured in 39 consecutive subjects who underwent defecography during a 1 year period. Using Monte Carlo data, the mean effective dose equivalent was estimated at $3.2 \pm 2.7 \mathrm{mSv}$. For comparison, the effective dose equivalent for barium enema examinations reported in the literature is 10-17 mSv. The ovarian dose was $12 \pm 6 \mathrm{mSv}$, which should be compared to the gonadal dose for barium enema reported in the literature of 3.8-16 mSv. The testes are not in the primary beam, and therefore are only exposed to scattered radiation, hence its low received dose of $\leq$ $0.14 \mathrm{mSv}$.

Although defecography delivers a significant ovarian dose, the values are not exceptional. However, the procedure should not be performed routinely, but only when it is strictly indicated, especially in females in the childbearing age. 


\section{INTRODUCTION}

In recent years there is an increasing interest in the study of functional anorectal disorders by means of defecography. After a thick barium paste was introduced into the rectum, the patient was asked to defecate under fluoroscopy and the films were exposed in lateral projection. As a consequence of this examination technique, the ovaries are situated in the center of the primary $x$-ray field. Moreover, in this position the pelvis is the broadest part of the body resulting in a high absorbed dose. The testes are not within the primary beam and, therefore, are only exposed to scattered radiation. Our data indicated that $19 \%$ of the 155 consecutive patients who underwent defecography over a 4 year period were females in the childbearing age (younger than 40 years).

In order to get estimates of both somatic- and genetic risks associated with defecography, a study was performed in which organ doses were calculated from entrance radiation exposure to the patient, as measured with a flat ionization chamber in the primary beam, and published data from Monte Carlo calculations which give organ doses per unit of entrance exposure.

\section{MATERIALS AND METHODS}

Measurements were carried out in 39 consecutive subjects referred for defecography during a 1 year period. There were 15 males and 24 females, ranging from 24 to 81 years with a mean age of 54 years. The standardized technique of defecography has been described in detail previously (1). All examinations were performed while the patient sat on a special designed seat which was mounted on the footrest of a remote controlled examination table (Fluoro Diagnost 120, Philips Medical Systems, The Netherlands). Fluoroscopy and filming were done with a source-image distance of 1.25 metres and an input field select for the image intensifier of $36 \mathrm{~cm}$. The relevant stages of defecation were recorded on $105 \mathrm{~mm}$ format films. Doses in the pelvic organs were determined as follows. A flat, almost $x$-Ray transparant ionization chamber (Diamentor M1, PTW Freiburg) which was mounted directly behind the tubes diaphragm, was used to measure the exposure-area product of the primary beam. The calibration of this device was checked with an accurate exposuremeter (Capintec, model 192 A, Pittsburgh, USA). 
During defecography, several parameters were recorded, including: high tension $x$-ray tube, exposure-area product due to fluoroscopy and filming respectively, as were the number of $105 \mathrm{~mm}$ images. Among the patient data collected were: age, sex and hipwidth. The latter parameter is the distance that radiation has to penetrate in the lateral projections used in these studies.

The technical and patient data, served as input for the actual dose calculations. These calculations were performed with use of data from Monte Carlo simulations reported by Drexler et al. (2). These data consist of tables, with organ doses per unit entrance exposure, and are available for several standard projections and beam qualities.

The entrance exposure, required for using these tables, was calculated from the exposure-area product and the beam entrance area. The area was calculated from the size of the image on film and the measured mimification factor of the $x$-ray set-up with image intensifier and $105 \mathrm{~mm}$ camera system.

The calculations were performed with the aid of a computer, and corrections were applied for the (small) area of the beam that passed below the patient. Furthermore, a correction was applied for the hipwidth so far it differs from that of the phantom used in the Monte Carlo calculations. Although these corrections are approximate, they are preferable to no corrections at all.

\section{RESULTS}

Table 1 showes a wide variation of the number of pictures required to document the entire act of defecation, mainly due to the large interindividual variations in the speed of evacuation. As a result, there is also a large variability in the values of the dose-area-product, effective dose equivalent and ovarian dose. Figure 1 shows that $97 \%$ of the subjects have an effective dose equivalent of $<7 \mathrm{mSv}$ (mean: $3.2 \mathrm{mSv}$ ), while figure 2 shows that $95 \%$ of the surveyed females received an ovarian dose of $<20 \mathrm{mSv}$ (mean: $12.0 \mathrm{mSv}$ )

In one patient the initial film series was lost during processing, whereafter the examination was repeated, resulting in twice as much radiation dose. 
Table 1. Exposure values for defecography $(n=39)$

mean $\pm \mathrm{SD}$

No of pictures $(105 \mathrm{~mm})$

$k \vee p$

mAs

Field of view $\left(\mathrm{cm}^{2}\right)$

Exposure-area product ( $\mathrm{R} \mathrm{cm}^{2}$ )

Fluoroscopic dose fraction (\%)

Dose equivalent ovaries

Dose equivalent testes (mSv)

Effective dose equivalent (mSv)
$13 \pm 6$

$111 \pm 3$

$30 \pm 5$

$173 \pm 26$

$2006 \pm 785$

$43 \pm 13$

$12.02 \pm 6.16$

$\leq 0.14$

$3.24 \pm 2.71$
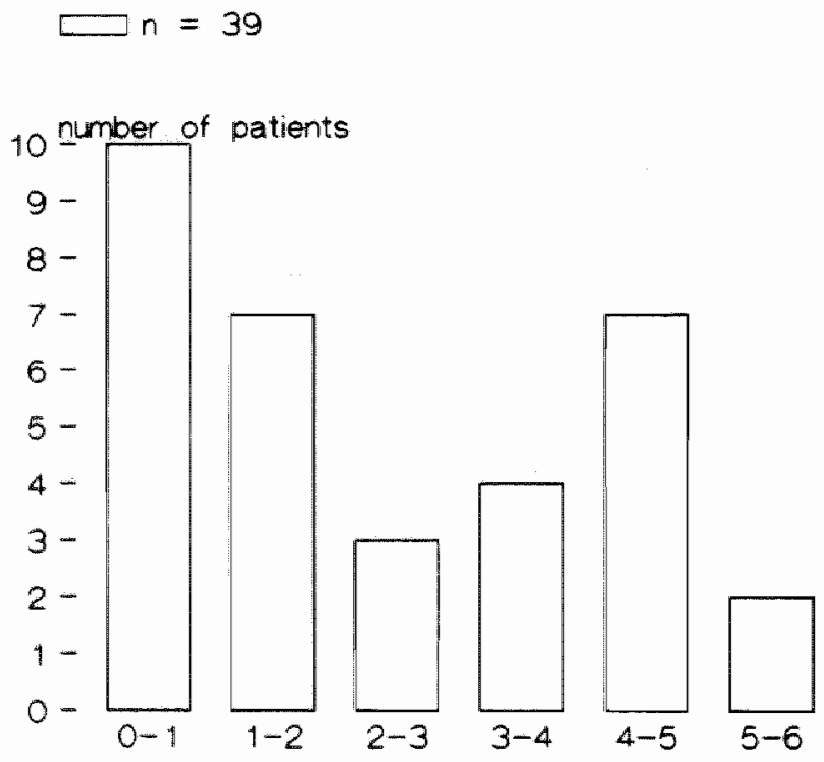

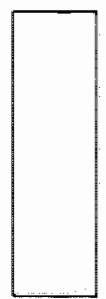

$6-7 \quad 14-15$

Effective dose equivalent (mSv)

Figure 1. Bar graph shows the distribution of the effective dose equivalent in 39 consecutive subjects who underwent defecography. 
$\square n=24$

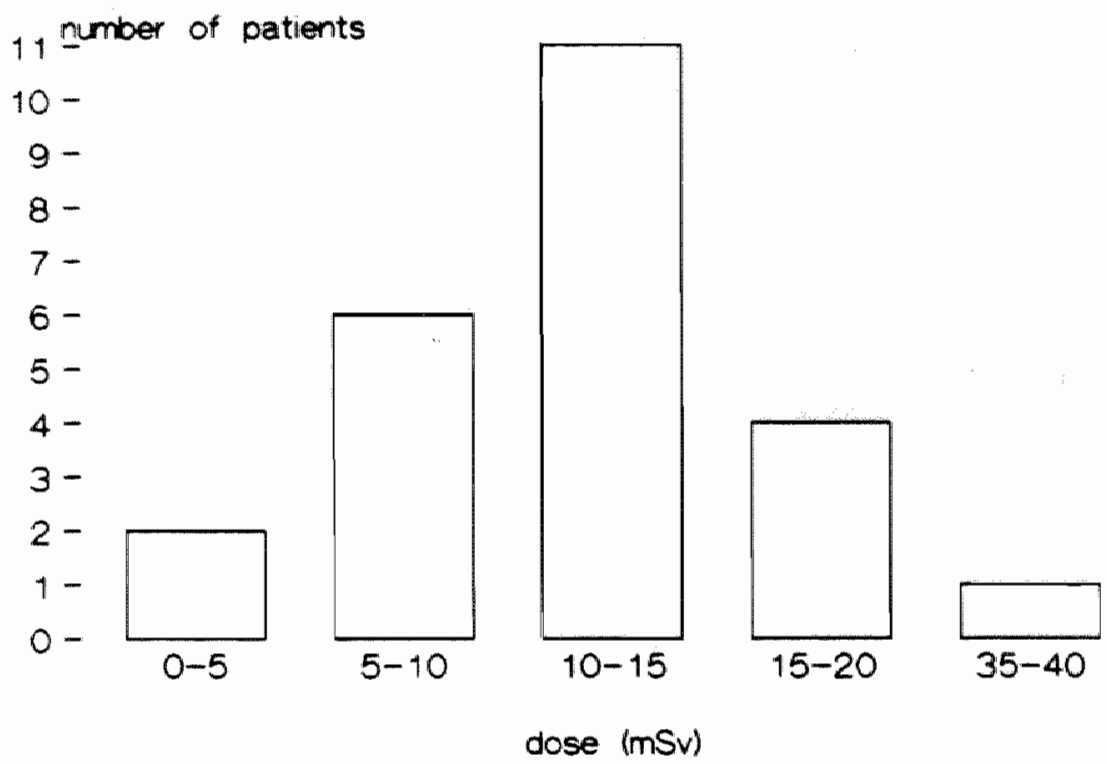

Figure 2. Bar graph demonstrates the distribution of the ovarian dose in 24 females who underwent defecography.

\section{DISCUSSION}

Several studies have been reported from different countries on radiation doses associated with the routine types of examination (3-7). Although defecography is a rather specialized technique, improvements in proctologic surgery and its simplified technique brought about an increasing interest in the study of functional anorectal disorders. Since no data are available in the literature, it is appropriate to estimate the radiation doses associated with this type of examination.

Our results indicated, that the mean effective dose equivalent was 3.2 mSv (Table 1). According to ICRP 26 (9), the radiation induced mortality risk factor is $1.25 \times 10^{-2} \mathrm{~Sv}^{-1}$. This implies that the mortality risk associated with defecography is on average $4 \times 10^{-5}$. The mean ovarian dose is $12 \mathrm{mSv}$ (Table 1). The stochastic genetic risk for hereditary effects, as expressed in the first two generations, according to ICRP 26 
(9), is $4 \times 10^{-3} \mathrm{~Sv}^{-1}$. So, the risk for the offspring of females who underwent defecography, amounts to $5 \times 10^{-5}$.

The testes are in principle not within the primary beam and, therefore, are only exposed to scattered radiation; hence its relative low received dose of $\leq 0.14 \mathrm{mSv}$ (Table 1).

For comparison, the effective dose equivalent due to natural background radiation is $\infty 2 \mathrm{mSvy}^{-1}(8)$. Barium enema studies, generally recognised as high dose procedures, lead to an effective dose equivalent of $10-17$ $\mathrm{mSv}(3,4)$, which should be compared to $0.5-6.0 \mathrm{mSv}$ due to defecography. The ovarian dose associated with barium enema studies is 3.8-16 $\mathrm{mSv}(4.5)$, to be compared with $6-18 \mathrm{mSv}$ caused by defecography.

It can therefore be stated, that defecography delivers a significant, but not exceptional, ovarian dose. For this reason, defecography should not be performed routinely, but only when it is strictly indicated, especially in females in the childbearing age. 


\section{REFERENCES}

1. Goei $R$, Baeten $C$, Arends JW. Solitary Rectal Ulcer Syndrome: Findings at Barium Enema Study and Defecography. Radiology 1988; 168: 303-306.

2. Drexler $G$, Panzer W, Widenmann $L$, Williams $G$, Zankl $M$. The Calculation of Dose from External Photon Exposures Using Reference Human Phantoms and Monte Carlo Methods. Part III: Organ Doses in X-Ray Diagnosis. Unchanged Reprint September 1985.

3. Maccia C, Benedittini M, Letaure $C$, Fagnani F. Doses to patients from diagnostic radiology in France. Health Physics 1988; 54: 397-408.

4. Rannikko S, Servomaa A, Ermakoff I, et al. Calculation of the estimated collective effective dose equivalent (S E) due to $X$-ray diagnostic examinations-estimate of the SE in Finland. Health Physics 1987; 53:31-36.

5. Shrimpton PC, Wall BF, Jones DG, Fisher ES, Hillier MC, Kendall GM, Harrison $\mathrm{RM}$. Doses to patients from routine diagnostic $x$-ray examinations in England. The British Journal of Radiology 1986; 59: 749-758.

6. Gray JE, Ragozzino MW, Van Lysel MS, Burke TM. Normalized Organ Doses for Various Diagnostic Radiologic Procedures. AJR 1981; 137: 463-470.

7. Kauffmann GW, Flemming K, Friedburg $H$, Schattenberg S. Einflüsse der Strahlenbelastung in der Röntgendiagnostik. Radiologe 1982; 22: 235-240.

8. United Nations Scientific Committee on Effects of Atomic Radiation. Ionizing radiation: sources and biological effects. (United Nations, New York 1982).

9. ICRP, 1977. Recommendations of the International Commission on Radiological Protection. Publication 26, Annals of the ICRP, Vol. 1(3) (Pergamon Press, Oxford). 



\section{Chapter 10}

\section{SUMMARY AND CONCLUSIONS}

Disorders of defecation are often seen in connection with the Irritable Bowel Syndrome (IBS).Literature contains numerous articles on this subject, yet there is no unanimity on the definition of IBS. Abdominal symptoms plus defecation disorders in the absence of an organic disease, is the definition given by many investigators, while others describe patients with defecation disorders without abdominal symptoms. The objective of most studies on IBS has been the investigation of disturbances of colonic motility as its underlying mechanism and little attention has been paid to disturbances of anorectal function as a possible etiologic factor. Moreover, in daily practice, patients with defecation disorders, whether or not accompanied by abdominal symptoms, generally are referred for coloscopy and biopsy or barium enema study. These procedures, however, are static examinations, enabling to detect organic abnormalities only. Since motility disorders are more and more, recognized as the underlying mechanism of bowel dysfunction, there exists a need to evaluate bowel motility.

In the anorectal region, electromyography and manometry are functional tests, which measure the condition and the function of the muscles which play a role in preserving anal continence and the mechanism of defecation. However, these are indirect procedures, and at present, their findings are considered nonspecific. Direct visualization of functional anorectal motility disorders seems warranted, and since the symptoms are closely related to the act of defecation, fluoroscopic monitored evacuation of rectally infused contrast material is a logic step in the search for a direct and physiologic method to evaluate anorectal function.

Since defecography was first described in 1952, there exists a variety of techniques to evaluate anorectal function radiologically. There are also 
different methods to interpret defecograms, so that the data of the various authors are difficult to compare.

The aim of this thesis, is to describe a simplified and standardized technique of defecography, and to evaluate its role in the detection of abnormalities of anorectal function in patients with defecation disorders, whether or not in connection with IBS.

In the mechanism of defecation, the levator ani, especially the puborectalis and the sphincter ani muscles play an important role, therefore a literature study and a cadaver study of the anatomy and a literature study of the physiology of these muscles have been described in chapter 2.

From a study of the literature, which have been described in chapter 3 , it became obvious that defecography has been applied since 1952 for the investigation of a variety of anorectal disorders. For unknown reasons, defecography is not in wide clinical use and has not become an integral part in most institutions, despite the fact that it is consdidered a useful technique for the detection of functional anorectal abnormalities as the underlying mechanism of defecation disturbances. Perhaps technical difficulties in the radiological performance of the study and limited surgical and therapeutical options account for this lack of interest. Refinements in proctologic surgical techniques, brought about renewed interest in the investigation of anorectal functional abnormalities in the early eighties. Chapter 4 dealt with a literature review of the normal and abnormal defecogram. Although there have been numerous publications on this subject, the motion patterns of the anorectum in asymptomatic subjects received only scant attention.

To provide a baseline for the study of abnormal function, an analysis of the function of the anorectum in subjects without defecation disorders was considered necessary and is described in chapter 5. From this investigation it appears, that the anorectal angle, considered by numerous authors as a measure of levator ari physiology is not a reliable parameter in this regard. There is a large interobserver and interindividual variability in its measurements during the succesive stages of defecation. Therefore, measurements of this parameter should not serve as the only criterion for diagnosis and treatment. Moreover, this study shows that abnormal changes of the anorectal wall during defecation straining may occur without causing symptoms. These abnormalities, however, may develop into a clinically manifested disorder. 
With knowledge of the above, the question can be raised as to whether defecography has the ability to discriminate the motion patterns of the anorectum of patients with defecation disorders from that of asymptomatic subjects. The study described in chapter 6 compares several defecographic parameters between a group of patients with defecation disturbances and a sex- and age- matched control group of asymptomatic subjects. Although there were slight differences in the means and standard deviations of several parameters between the two groups, these were not statistically significant. These findings, together with those described in the previous chapter, indicates that the changes of the anorectal angulation and changes of the positions of the anorectal junction during defecation straining should not be regarded as a reliable parameter for the physiology of the levator ani and sphincter ani muscles. In the same study the occurrence of anorectal wall abnormalities during defecation straining was investigated in 3 patient groups: the control group, the matched patient group and the entire group of 155 consecutive patients who underwent defecography for a variety of defecation disorders. There were nearly twice as many functional abnormalities of the rectal wall in both symptomatic groups, compared to the controls. So, in our opinion, it is most likely that these anatomical abnormalities are the cause of the disturbances of defecation and that the main role of defecography is to detect these changes and to serve as an anatomic guide to surgical therapy, if any.

It has been known for a long time that several patients with a long history of straining at stool may develop the so called solitary rectal ulcer. This condition consists of benign rectal mucosal lesions which may cause rectal bleeding or mucus discharge and which most probably are caused by mechanical injury during defecation straining. To asses the role of defecography in the evaluation of the condition, the procedure was performed in 16 patients with histologically proved solitary rectal ulcer. To asses the value of barium enema study in the condition, the study was performed in 15 patients. The results of this study are described in chapter 7 . In 14 out of 16 patients, the defecograms were abnormal, and included: rectal intussusception whether or not accompanied by a rectocele, rectal prolapse, spastic pelvic floor and abnormal perineal descent. In 9 out of 15 patients, the findings at barium enema study were nonspecific and included: rectal stricture, granularity of the rectal mucosa and thickened rectall folds. The conclusion from this study is, that the rectal lesions in the solitary rectal ulcer syndrome are the result of 
anorectal motility disorders, and that defecography is a useful method to detect these abnormalities. Although barium enema study plays no important role in the evaluation of the solitary rectal ulcer syndrome, thickened rectal folds were the most frequent findings in our study. This sign in a patient with a proper clinical history of a long period of straining at stool, accompanied with rectal bloodloss or mucus discharge, are likely to suggest the syndrome, and further defecographic evaluation is indicated.

Rectal intussusception and rectal prolapse are the most frequent findings at defecography. In our institution, twenty three patients with these disorders and with longstanding symptoms were corrected surgically. To investigate whether, and to what extent these conditions were responsible for the defecation disorders in the preoperative stage and to evaluate the role of defecography in the detection of these conditions, a comparative study has been performed of the pre- and postoperative defecograms and its respective symptomatology. The results of this study are described in chapter $\mathbf{8}$. There is a close relationship between the appearances at the postoperative defecograms and the symptomatology, in 20 out of 23 patients. Despite this small series and a short follow-up period of three months, we think that rectal intussusception and rectal prolapse are most likely the underlying cause of defecation disorders and that defecography is a useful method to detect these changes in the preoperative stage. Since there were no recurrences in the patients with rectal prolapse and there was complete relationship between the presence or absence of the solitary rectal ulcer and the postoperative symptoms in all cases, a clinical or defecographic finding of a rectal prolapse and the presence of a solitary rectall ulcer in association with a rectal intussusception, are the best indicators for surgical correction.

As a consequence of the examination technique, the ovaries are situated in the center of the primary $x$-ray field, and because in lateral projection the pelvis is the broadest part of the body, its internal organs receive a maximum of absorbed dose. Therefore, insight in the amount of radiation doses received by the gonads was considered necessary. The results of the study of 39 consecutive subjects are described in chapter 9 . The mean effective dose equivalent, as an expression of total patient risk, was $3.2 \pm 2.7 \mathrm{mSv}$. In the literature consulted on this subject, the effective dose equivalent delivered by barium enema examinations is 10-17 mSv. The mean dose equivalent for the ovaries was $12 \pm 6 \mathrm{mSv}$, 
compared to a gonadal dose equivalent of 3.8-16 $\mathrm{mSv}$ for barium enema study, reported in the literature. The testes received a relatively low dose, because they were only exposed to scattered radiation.

Although defecography delivers a significant radiation dose, the values are not exceptional. From the point of view of radiation exposure, however, defecography should not be performed on a routine basis, but only when it is strictly indicated especially where females of childbearing age are concerned.

In general, defecography is a useful modality to identify patients with functional anorectal disorders. Especially in patients with clinical suspicion of the solitary rectal ulcer syndrome, dynamic radiological investigation of the anorectal region is indicated, to detect the underlying mechanism and to establish the diagnosis. However, defecography should be performed only when it is strictly indicated because it is associated with high radiation exposure, especially with respect to the ovaries. 
' 


\section{SAMENVATTING}

Defaecatiestoornissen vormen een belangrijke factor bij het zogenaamde "Irritable Bowel Syndrome" (IBS). Hoewel er in de literatuur geen eenduidige definitie van het IBS is te vinden, wordt het door vele auteurs beschouwd als een syndroom welke gekenmerkt wordt door buikklachten gepaard met defaecatie stoornissen zonder dat er een organische oorzaak kan worden aangetoond. Als onderliggende oorzaak wordt in het algemeen motiliteitstoornissen van het maagdarmkanaal beschouwd, al dan niet in samenhang met psychische factoren. Vele onderzoeken met betrekking tot het IBS handelen over motiliteitstoornissen van de dikke darm en, hoewel defaecatiestoornissen een belangrijk onderdeel van het IBS vormen, wordt er nauwelijks aandacht besteed aan functiestoornissen van het anorectaal gebied. In de dagelijkse praktijk wordt bij patiënten met defaecatiestoornissen een organische oorzaak uitgesioten met behulp van radiologisch- of endoscopisch onderzoek van de dikke darm. Met deze technieken is men echter niet in staat de motiliteit van de dikke darm te onderzoeken. Aangezien motiliteitstoornissen steeds meer gezien worden als de onderliggende oorzaak van defaecatiestoornissen, bestaat er behoefte aan diagnostische middelen om de motoriek van het maagdarmkanaal te evalueren.

Electromyografie en manometrie van het anorectaal gebied meten de conditie en functie van de bekkenbodem- en sfincter ani spieren, welke een rol spelen bij de defaecatie en bij het handhaven van het continentie mechanisme. Beide technieken zijn echter indirekte methoden en bovendien zijn de meetresultaten niet specifiek. Defaecografie is een fysiologische methode waarbij de functie van het anorectum tijdens de daadwerkelijke defaecatie radiologisch in beeld wordt gebracht. Met deze techniek is het niet alleen mogelijk de functie van de bekkenbodem 
spieren, met name van de puborectalis, te bestuderen maar is het ook mogelijk vormveranderingen van het anorectum op te sporen welke aanleiding geven tot defaecatiestoornissen.

Defaecografie is echter geen nieuwe techniek. Sinds de eerste beschrijving door Brodèn in 1952, werden verschillende variaties op de methode beschreven en werden verschillende criteria gehanteerd bij de interpretatie van het defaecogram, waardoor de literatuur over dit onderwerp een onsamenhangend geheel vormt. Het doel van dit proefschrift is een eenvoudige en gestandaardiseerde techniek voor defaecografie te beschrijven. Tevens wordt beoogd de waarde van defaecografie bij het opsporen van de onderliggende oorzaak van funktionele defaecatie stoornissen te bepalen.

Bij de defaecatie spelen de bekkenbodem spieren, vooral de puborectalis, en de sfincter ani spieren een belangrijke rol. Om het defaecogram te kunnen beoordelen is enig inzicht in de anatomie en de werking van deze spieren noodzakelijk. Derhalve wordt in hoofdstuk 2 een literatuur studie en een kadaverstudie van genoemde structuren beschreven.

In hoofdstuk 3 wordt een historisch overzicht gegeven waaruit blijkt dat, hoewel thet reeds lange tijd beschreven is, defaecografie niet algemeen wordt toegepast in de praktijk van alledag. Waarschijnlijk wordt dit veroorzaakt door technische moeilijkheden bij het uitvoeren van het onderzoek en/of door beperkte mogelijkheden bij de behandeling van functiestoornissen van het anorectum. Met de verbetering van proctologische chirurgische technieken, ontstond in het begin van de jaren ' 80 een l:ernieuwde belangstelling voor de radiologische evaluatie van functiestoornissen van het anorectum. De meeste publicaties geven een beschrijving van de verschillende abnormaliteiten op het defaecogram, terwijl er nog onvoldoende informatie voorhanden was met betrekking tot het normaal defaecogram. Nadat in hoofdstuk 4 de techniek van defaecografie wordt beschreven en de definities van het normale en het afwijkende defaecogram, zoals in de literatuur aangegeven, worden geformuleerd, wordt in hoofdstuk 5 een studie beschreven die betrekking heeft op de defaecogrammen van 32 individuen zonder defaecatieklachten. Uit deze studie blijkt dat de verschillende parameters, zoals de anorectale hoek, de positie van het anorectale overgangsgebied, en de wijdte van het anale kanaal, geen konsistente weergave zijn van de werking van de levator ani- en de sfincter ani spieren. Er blijkt met name een grote interindividuele en interwaarnemer variabiliteit te bestaan. Dergelijke metingen kunnen dan ook niet als enige parameter voor 
behandeling dienen. Tevens is uit deze studie gebleken dat vormveranderingen van het anorectum asymptomatisch kunnen zijn.

De vraag doet zich thans voor of defaecografie een discriminerend vermogen heeft ten aanzien van de anorectale motiliteit van patiênten met defaecatieklachten ten opzichte van asymptomatische individuen. In hoofdstuk 6 wordt een studie beschreven waarbij de verschillende defaecografische parameters bij patiënten met klachten worden vergeleken met die bij een vergelijkbare controle groep. Er blijkt geen significante verschillen te bestaan tussen beide groepen met betrekking tot de verschillende metingen. Deze bevindingen onderstrepen nogmaals het feit dat de verschillende defaecografische metingen de werking van de bekkenbodem spieren en de sfincter ani spieren onvoldoende weergeven. In dezelfde studie wordt het voorkomen van anorectale vormveranderingen in 3 groepen patiënten nagegaan: in de asymptomatische groep bestaande uit 32 individuen (controle groep), in een vergelijkbare symptomatische groep wat betreft geslachtsverdeling en leeftijdsverdeling, en in de hele groep van 155 patiënten die gedurende 4 jaar defaecografie hebben ondergaan in verband met allerlei soorten defaecatieklachten. Uit deze studie blijkt dat in beide symptomatische groepen, bijna twee maal zoveel vormveranderingen voorkomen dan in de asymptomatische groep. Er kan derhalve geconcludeerd worden dat anorectale vormveranderingen welke optreden tijdens de defaecatie, waarschijnlijk de oorzaak zijn van defaecatiestoornissen en dat defaecografie een adequate methode is om dergelijke afwijkingen te detecteren. Het is reeds lang bekend dat patiënten met langbestaande defaecatieklachten het zogenaamde solitair rectum ulcus ontwikkelen. Deze afwijking bestaat uit een benigne laesie van de mucosa van het rectum welke aanleiding kan geven tot rectaal bloedverlies en slijmatscheiding. Om de waarde van het defaecogram bij de evaluatie van deze afwijking te bepalen, werden bij 16 patiënten met een pathologisch anatomisch bewezen solitair rectum ulcus defaecografie verricht, en om na te gaan wat de waarde van het $x$-colon bij de detectie van deze afwijking is "werd dubbelkontrast onderzoek van het rectum verricht bij 15 van de 16 patiënten. De resultaten van deze studie worden beschreven in hoofdstuk 7 . Bij 14 van de 16 patiënten lieten de defaecogrammen afwijkingen zien zoals: rectale intussusceptie, al dan niet gepaard met een rectocèle, rectum prolaps, het spastisch bekkenbodem syndroom en een abnormaal lage positie van het perineum in rust en tijdens persen tengevolge van slapte van de bekkenbodem spieren. Bij 7 van de 15 patiënten 
vertoonde het barium onderzoek afwijkingen zoals: stricturering, granulaire afwijkingen van het slijmvlies en oedemateuze verbreding van de plooi van Houston. Uit deze studie wordt gekonkludeerd dat de beschadiging van het rectum slijmvlies bij het solitair rectum ulcus waarschijnlijk wordt veroorzaakt door motiliteitstoornissen en vormafwijkingen van het anorectum en dat defaecografie een goede methode lijkt om dergelijke afwijkingen bij patiënten met het solitair rectum ulcus, op te sporen. Hoewel barium onderzoek geen rol lijkt te spelen bij het opsporen van het solitair rectum ullcus, dient men bij een patient met verbreding van de plooi van Houston en langbestaande defaecatie klachten gepaard met rectaal bloedverlies en/of slijmafscheiding bedacht te zijn op het syndroom. Bij deze patiënten is defaecografie geindiceerd om de onderliggende corzaak op te sporen.

Intussusceptie en prolaps van het rectum zijn afwijkingen die vaak middels defaecografie aangetoond worden. In de loop van 4 jaar, werden bij 20 patiënten met een intussusceptie en bij 3 patienten met een rectum prolaps, operatieve korrectie verricht mede in verband met langdurig bestaande klachten. Om na te gaan in hoeverre deze afwijkingen de oorzaak waren van de defaecatie klachten en om de rol van defaecografie bij het opsporen van deze afwijkingen te bepalen, werd 2-3 maanden na de operatie bij alle patiënten controle defaecografie verricht en werd nauwkeurige postoperatieve anamnese afgenomen. De resultaten van deze studie worden beschreven in hoofdstuk 8 . De defaecogrammen van alle 3 patiënten met een prolaps waren genormaliseerd en allen waren klachtenvrij. Van de 20 patiënten met een intussusceptie, waren er 13 klachtenvrij geworden en vertoonden de postoperatieve defaecogrammen geen afwijkingen. Bij 2 patiënten bleven de klachten en de afwijkingen op het postoperatieve defaecogram bestaan. Bij nog 2 patiënten gingen recidief klachten gepaard met recidief afwijkingen op het defaecogram. Bij 3 patiënten bleven de klachten postoperatief bestaan, terwijl de defaecogrammen genormaliseerd waren. Er kan derhalve gesteld worden dat bij 20 van de 23 geopereerde patiënten er een verband was tussen de postoperatieve symptomatologie en het postoperatieve defaecogram. Hoewel het patiënten materiaal beperkt was en de vervolgperiode kort, lijken rectum prolaps en rectum intussusceptie de oorzaak van de klachten te zijn. Aangezien er geen recidieven optraden in de 3 patiënten met een rectum prolaps en er een duidelijk verband werd aangetoond tussen het al dan niet aanwezig zijn van het solitair rectum ulcus en de postoperatieve symptomatologie, kan voor- 
zichtig gesteld worden dat rectum prolaps en rectum intussusceptie gepaard met een solitair rectum ulcus, goede indikaties zijn voor chirurgische correctie.

Aangezien er geen gegevens in de literatuur beschikbaar zijn omtrent stralingsdoses bij defaecografie, werd een studie hiernaar verricht bij 39 opeenvolgende patiënten. Het gemiddelde effectieve dosis equivalent, als een maat voor de totale risico voor de patiënt, bedraagt $3.2 \pm 2.7$ $\mathrm{mSv}$. Het effectieve dosis equivalent bij het colon onderzoek volgens de opgave in de literatuur bedraagt $10-17 \mathrm{mSv}$. Het gemiddelde dosis equivalent voor de ovariae bedraagt $12 \pm 6 \mathrm{mSv}$. Voor het colon onderzoek bedraagt deze, volgens gegevens in de literatuur, $3.8-16 \mathrm{mSv}$.

Aangezien de testikels niet in de primaire bundel zijn gelokaliseerd tijdens defaecografie, staan deze organen slechts bloot aan strooistraling van $<0.14 \mathrm{mSv}$.

Hoewel de stralingsdoses bij defaecografie aanzienlijk zijn, vormen deze waarden geen uitzondering in vergelijking met enkele andere stralenbelastende radiologische onderzoeken. Uit oogpunt van stralingsbescherming dient defaecografie echter niet routinematig te worden verricht en alleen op weloverwogen indikatie, vooral indien het vrouwelijke patiënten betreft in de vruchtbare periode.

In het algemeen kan gesteld worden dat defaecografie een bruikbare onderzoekmethode is om patiënten met defaecatieklachten, nadat een organische oorzaak is uitgesloten, te evalueren. In het bijzonder bij patiënten met het solitair rectum ulcus, is defaecografie geindiceerd om erachter te komen wat de onderliggende oorzaak is. 


\section{APPENDIX}

Vragenlijst welke gehanteerd werd bij het selecteren van individuen zonder defaecatieklachten ten behoeve van de studie beschreven in hoofdstuk 5.

Naam:

Geslacht:

$\mathrm{m} / \mathrm{v}$

Leeftijd:

Indicatie voor het colon onderzoek:

Defaecatie frequentie:

Persen:

Bloedbijmenging:

Slijmbijmenging:

Gevoel van onvolledige ontlediging:

Incontinentie:

Vroegere buikoperaties:

...x per dag

ja / nee

ja / nee

$\mathrm{ja} / \mathrm{nee}$

ja / nee

ja/ nee

ja/ nee

Doorgemaakte / aanwezige ziektes in het anorektaal gebied ( hemorrhoiden, abcessen, fistels, fissuren ):

ja / nee 



\section{ACKNOWLEDGEMENTS}

This study was performed at the Department of Radiology of the University Hospital Maastricht with the support of technicians and residents too many to mention. The persons listed below made special contributions:

Review of the manuscript:

Prof.Dr.J.M.A. van Engelshoven (1) Prof. Dr. B.K Janevski (1) Dr.C.G.M.I. Baeten (2)

Production of contrast material: Drs. A.J. Beysens (3)

Construction of defecography chair: Jef Ackermans (1)

Anatomical dissection:

Statistical advices:

Patient coordination:

Photography:

Secretarial assistance:

Schematic drawings:
Drs.G.M.A. Lataster (4)

Dr. H.J.A. Schouten (5)

Dr. G.J. Kemerink (1)

Hetty Nelissen (1)

Jo Houben (6)

Marjo Trynes (1)

Christianne Schiffer (1)

Chris Voskamp (6)

(1) Department of Radiology, University Hospital Maastricht

(2) Department of Surgery, University Hospital Maastricht

(3) Department of Clinical Pharmacy and Toxicology, University Hospital Maastricht

(4) Department of Anatomy and Embryology, University of Limburg, Maastricht

(5) Department of Medical Statistics, University of Limburg, Maastricht

(6) Audiovisual Services, University Hospital Maastricht 


\section{CURRICULUM VITAE}

Geboren op 25 Juni 1948 te Salatiga (Indonesië).

1961 - 1963: Sekolah Menengah Pertama "Pangudi Luhur" te Salatiga.

1963 - 1964: Sekolah Menengah Atas "Santo Josef" te Surakarta.

1965 -1968: Voortzetting Middelbare School opleiding (HBS-B) aan het "Eykhagen college" te Schaesberg.

1968 - 1976: Artsenstudie aan de Katholieke Universiteit te Nijmegen.

1976 - 1977: $\quad$ Militaire Dienstplicht.

1977 - 1978: $\quad$ Assistentschap Interne Geneeskunde "St. Elisabeth Ziekenhuis" te Amersfoort.

1978 - 1979: Assistentschap Interne Geneeskunde "St. Lambertus Ziekenhuis" te Helmond.

1979 - 1983: In opleiding tot Radiodiagnost in het "St. Annadal Ziekenhuis" te Maastricht.

April - Juni 1983: Verblijf op de "Section of Gastrointestinal Radiology of the Hospital of the University of Pennsylvania" te Philadelphia, USA en op de "Division of Ultrasound of the Thomas Jefferson University Hospital" te Philadelphia, USA.

April 1984 - Februari 1985:

Waarneming op de afdeling Radiodiagnostiek "St. Josef Ziekenhuis" te Kerkrade.

1985 - heden: Staflid afdeling Radiodiagnostiek Academisch Ziekenhuis Maastricht. 